\title{
Quo Vadis: AlCr-Based Coatings in Industrial Applications
}

\author{
Joerg Vetter ${ }^{1, *}$, Anders O. Eriksson ${ }^{2}$, Andreas Reiter ${ }^{2}$, Volker Derflinger ${ }^{2}$ and Wolfgang Kalss ${ }^{2}$ \\ 1 Oerlikon Balzers Coating Germany GmbH, Am Boettcherberg 30-38, 51427 Bergisch Gladbach, Germany \\ 2 Oerlikon Balzers, Oerlikon Surface Solutions AG, Iramali 18, LI-9496 Balzers, Liechtenstein; \\ anders.o.eriksson@oerlikon.com (A.O.E.); andreas.reiter@oerlikon.com (A.R.); \\ Volker.Derflinger@oerlikon.com (V.D.); wolfgang.kalss@oerlikon.com (W.K.) \\ * Correspondence: joerg.vetter@oerlikon.com
}

check for updates

Citation: Vetter, J.; Eriksson, A.O.; Reiter, A.; Derflinger, V.; Kalss, W. Quo Vadis: AlCr-Based Coatings in Industrial Applications. Coatings 2021, 11, 344. https://doi.org/ 10.3390/coatings11030344

Academic Editor:

Armando Yáñez-Casal

Received: 12 February 2021

Accepted: 15 March 2021

Published: 18 March 2021

Publisher's Note: MDPI stays neutral with regard to jurisdictional claims in published maps and institutional affiliations.

Copyright: (c) 2021 by the authors. Licensee MDPI, Basel, Switzerland. This article is an open access article distributed under the terms and conditions of the Creative Commons Attribution (CC BY) license (https:/ / creativecommons.org/licenses/by/ $4.0 /)$.

\begin{abstract}
AlCr-based hard nitride coatings with different chemical compositions and architectures have been successfully developed and applied over the last few decades. Coating properties are mainly influenced by deposition conditions and the $\mathrm{Al} / \mathrm{Cr}$ content. The fcc structure is dominant for an $\mathrm{Al}$-content up to $\mathrm{Al}_{0.7} \mathrm{Cr}_{0.3} \mathrm{~N}$ and is preferred for most cutting applications. Different $(\mathrm{AlCrX}) \mathrm{N}$ alloying concepts, including $X=\mathrm{Si}, \mathrm{W}, \mathrm{B}, \mathrm{V}$, have been investigated in order to enhance oxidation resistance and wear behaviour and to provide tribological properties. AlCr-based oxynitrides and even pure oxides $\left(\mathrm{Al}_{1-x} \mathrm{Cr}_{x}\right)_{2} \mathrm{O}_{3}$ with different crystalline structures have been explored. Multiand nanolayered coatings within the AlCr materials system, as well as in combination with (TiSi)N, for example, have also been implemented industrially. The dominant deposition technology is the vacuum arc process. Recently, advanced high-power impulse magnetron sputtering (HiPIMS) processes have also been successfully applied on an industrial scale. This paper describes basic coating properties and briefly addresses the main aspects of the coating processes as well as selected industrial applications.
\end{abstract}

Keywords: AlCr-based; CrAl-based; $(\mathrm{AlCrX}) \mathrm{N} ;\left(\mathrm{Al}_{1-x} \mathrm{Cr}_{x}\right)_{2} \mathrm{O}_{3}$; arc; HiPIMS; nanolayers; nanocomposite; structure; properties

\section{Introduction}

Surface solutions using PVD (Physical Vapor Deposition) coatings for the improvement of the wear resistance and tribological properties of tools and components started on an industrial scale around the middle of the 1970s in the Soviet Union. The first component coating was MoN [1]. The first successful industrial coating for tooling applications in Western Europe was the "golden" TiN coating applied by low-voltage arc evaporation developed at Oerlikon Balzers [2]. A modification of this coating with carbon followed, and the TiNC coating types were implemented in mass production at the end of the 1980s. In parallel, Cr-based coatings were also introduced, including modifications using oxygen and carbon [3]. Besides nitride, carbonitride and oxynitride coatings, hard amorphous carbon coatings, the DLC (Diamond Like Carbon) coatings, were developed and applied as well $[4,5]$. These coatings were deposited using several coating architectures [6]. Many coating developments focused on alloying TiN using different additional elements [5].

The most important industrial development after TiN, CrN and DLC was achieved in the Ti-Al-N system [7]. Around the year 2000, this coating family was the dominant coating, especially for cutting tools [8,9]. However, in the Ti-Al-N system, only minor improvements of coating properties and the performance of cutting tool applications were possible, e.g., by alloying with $\mathrm{Si}, \mathrm{Y}, \mathrm{Cr}, \mathrm{C}, \mathrm{O}$ [10-13]. A big step forward was achieved through the investigation of totally new coating compositions. This led to the development of a new coating generation based on Al-Cr-N. Coatings in the AlCrN system span the compositional range from Al-rich to $\mathrm{Cr}$-rich. In this paper, the terminology $\mathrm{CrAl}$-based is used for coatings with a $\mathrm{Cr}$ content that is higher than that of $\mathrm{Al}(\mathrm{Cr} / \mathrm{Al}>1$ in at.\%), and conversely, AlCr-based is used for coatings in which $\mathrm{Al} / \mathrm{Cr}>1$. 
Results dealing with coatings with a low $\mathrm{Al}$ content $(\mathrm{Al} /(\mathrm{Al}+\mathrm{Cr})$ ratio $<0.5)$ and (CrAl)N coatings, deposited by sputtering, were published for the first time in $1990[14,15]$. In the same year, coatings with an $\mathrm{Al} /(\mathrm{Al}+\mathrm{Cr})$ composition of about 0.5 deposited using a modified hollow cathode discharge process were also presented [16]. Arc evaporation was used to deposit $(\mathrm{AlCr}) \mathrm{N}$ coatings with a high $\mathrm{Al}$ content with an $(\mathrm{Al} /(\mathrm{Al}+\mathrm{Cr})$ ratio of $>0.5[17,18]$. The first multilayer coating with an $\mathrm{Al}$ content greater than the $\mathrm{Cr}$ content was a multilayer architecture with $\mathrm{CrN}$ [19]. Another big step was the development of (TiSi)N coatings [20]. Coating solutions were also developed which combined the two coating types in multilayer structures [21].

A challenge for turning tools was, and still is in part, the development of alphaalumina using PVD. A PVD solution to add metallic doping elements to aluminium was patented in 1992 [22]. Processes to deposit oxides based on arc evaporation were successfully developed on the basis of Al-Cr cathodes [23].

This paper will review the main industrial-oriented coating developments using CrAl- and AlCr-based coatings, covering a wide variety of chemical and structural fields as well as architectures. The main deposition methods used will be described briefly. The review will concentrate on arc deposition processes, although sputtering techniques, including high-power impulse magnetron sputtering (HiPIMS), will be discussed as well. The main focus is on arc deposition processes and nitride coatings with an $\mathrm{Al}$ content greater than the $\mathrm{Cr}$ content and on ( $\mathrm{AlCr}$ ) ON coatings. Coatings with a cubic structure and various multilayer coatings are used most commonly in industrial applications. Selected application examples will be presented in the last section.

\section{Deposition Technologies and Coating Systems}

Various deposition technologies have been used to synthesise ( $\mathrm{CrAl}) \mathrm{N}$ and $(\mathrm{AlCr}) \mathrm{N}$ coatings over a period of about 30 years. Basic information about the deposition technologies is beyond the scope of this review. The interested reader is invited to look at available publications [24-31]. Some more exotic evaporation methods are hollow cathode arc evaporation [16] and activated reactive evaporation [32]. The first application of AlCr-based coatings for cutting tools deposited by hollow cathode arc was mentioned very early $[16,33]$. However, primarily sputtering processes and arc processes were used both for basic investigations as well as for applications.

The first reported (CrAl)N coatings were DC (Direct Current) magnetron sputtered [14,15]. The first arc coatings were deposited using elemental cathodes of pure $\mathrm{Al}$ and pure $\mathrm{Cr}$ [17]. The first multilayer coating $(\mathrm{AlCr}) \mathrm{N}$ was $(\mathrm{AlCr}) \mathrm{N} / \mathrm{CrN}$ deposited by arc [19]. Sometimes even hybrid methods, such as arc plus hollow cathode discharge [34] or, more commonly, arc plus sputtering [35], have been used. Alloyed CrAl-based and AlCr-based coatings are most commonly deposited either by magnetron sputtering or by arc evaporation. For sputtered coatings, the preferred methods are various HiPIMS processes in industrial applications, e.g., the S3p process [30]. The deposition of alpha alumina coating is based on a dedicated pulsed arc process, the P3e process [23].

It should be mentioned that the main differences between arc deposition processes and sputtering are:

Growth defects: Arc-deposited coatings have more growth defects in the coating than sputtered coatings due to macroparticle generation in the arc evaporation process. Sputtered coatings are thus preferred in applications requiring particularly low surface roughness.

Growth rate: The arc process allows a higher growth rate to be achieved than sputtering, depending on the PVD system set-up.

Degree of ionisation and ion energies: Arc evaporation is known to produce plasmas with a high degree of ionisation. Multiple charge states are formed as well in arc evaporation [36]. Sputtering processes are characterised by lower degrees of ionisation [26].

Energy consumption: The specific energy consumption of the arc process is lower than that of sputtered coatings for the same coating thickness [37]. 
Process stability: Arc processes tend to exhibit higher process stability than sputtering processes.

Larger coating volumes: Arc processes can be more easily upscaled for coating long parts (several metres).

The different basic methods used for CrAl-based and AlCr-based coatings are listed here briefly.

\subsection{Arc Deposition Methods}

CrAl-based and AlCr-based coatings are deposited by reactive direct vacuum arc using either elemental cathodes or composite cathodes. The first $(\mathrm{CrAl}) \mathrm{N}$ and $(\mathrm{AlCr}) \mathrm{N}$ coatings were deposited by the reactive co-evaporation of elemental chromium and aluminium cathodes available at that time [17-19].

The first composite cathodes suitable for arc evaporation manufactured by a powder metallurgical process were produced by Plansee AG, Austria, and were used successfully for tool coatings in 1995 [38]. Later, composite cathodes became the standard, especially in industrial applications $[39,40]$. A special pulsed process was developed for alpha $\left(\mathrm{Al}_{1-x} \mathrm{Cr}_{x}\right)_{2} \mathrm{O}_{3}$ coatings, the P3e process [23]. The main goal of the pulsing is to overcome process difficulties generated by the oxide process (cathode, anode reactions).

\subsection{Sputtering Methods}

\subsubsection{DC and RF Sputtering}

Several sputtering methods as well as combinations of different sputtering methods have been used to deposit both CrAl-based and AlCr-based coatings from elemental or composite cathodes. Even special processes based on the combination of composite targets combined with elemental targets have been realised [41]. The first CrAl-based coatings were deposited by reactive DC magnetron sputtering of a composite target $\left(\mathrm{Cr}_{75} \mathrm{Al}_{75}\right)[14,15]$. Additionally, newer research on a laboratory scale as well as industrial-scale PVD systems are using DC magnetron sputtering [41-46]. It should be noted that special magnetic field configurations can be achieved within the PVD systems by means of the magnetron set-ups, e.g., the CFUBM (Closed Field Unbalanced Magnetron Sputtering) [47,48]. RF (Radio Frequency) sputtering has been used for basic investigation $[49,50]$. Even the combination of RF sputtering plus DC sputtering has been applied [51,52], though RF sputtering is typically not used for industrial applications.

\subsubsection{Standard Pulsed Sputtering and HiPIMS}

Besides standard pulsed magnetron sputtering [41], the mode of dual pulsed magnetrons has also been used [48]. The most advanced pulsed sputtering method is highpower impulse magnetron sputtering. Pulses with peak power densities in the range of several hundred $W / \mathrm{cm}^{2}$ up to several thousand $W / \mathrm{cm}^{2}$ are achieved in classic high-power impulse magnetron sputtering (HiPIMS), also referred to as HPPMS, MPP or HIPAC. The pulse duration is usually in the range of 25 to $250 \mu$ s [41,53-56]. The longest pulse lengths of around $1000 \mu$ s are used in the case of MPP [57].

A dedicated HiPIMS process, known as the S3p process, is a process that runs with a constant pulse current and can operate using longer pulses than the classic HiPIMS process. The pulse duration often lies in the range of several milliseconds [30].

\subsection{Industrial Coating Systems}

A brief description of selected aspects of industrial systems will be provided here. In-depth descriptions of deposition systems are available elsewhere $[27,30]$. Both system configurations, set-ups with magnetrons and set-ups with arc evaporators, use particle sources with either a circular, rectangular or tubular geometry for the active evaporation surfaces, as shown in Figure 1. The circular form dominates for arc evaporation, whereas the rectangular and the cylindrical forms are used most commonly for sputtering. In 
addition to arc and sputtering systems, hybrid systems, e.g., arc plus HiPIMS, are also in use [29].

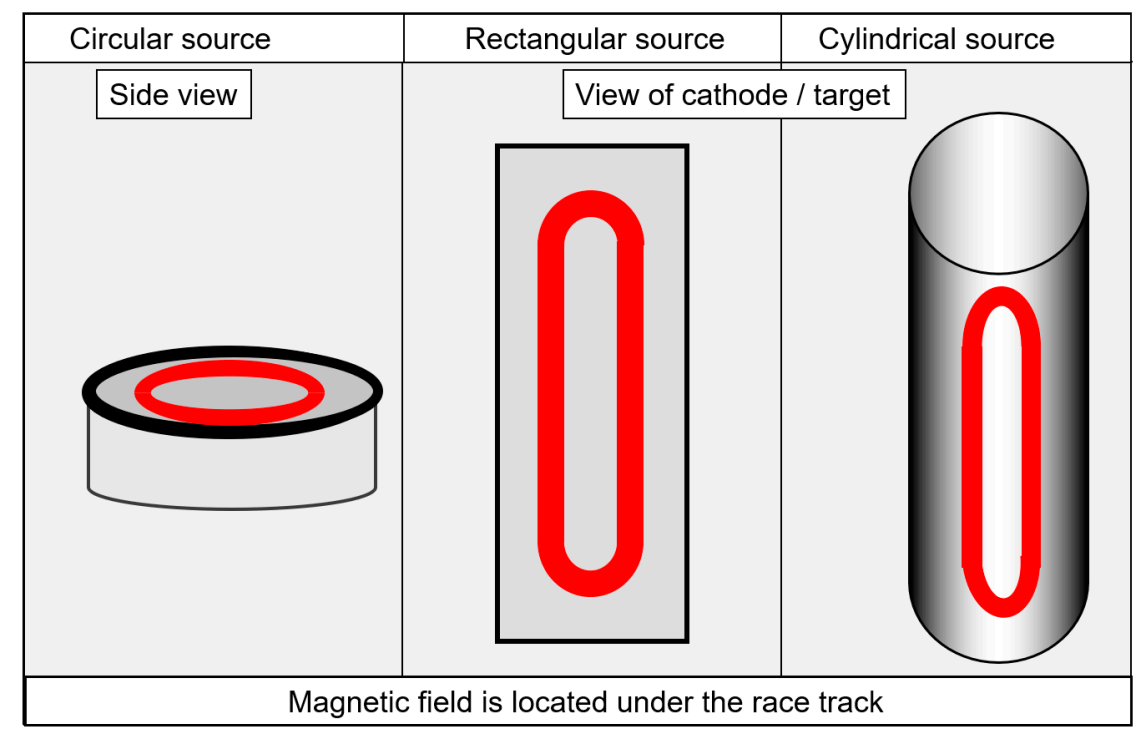

Figure 1. Schematic drawing of the circular, rectangular or tubular active evaporation surfaces, redrawn after [27], original (C) Vulkan-Verlag, Germany.

For the deposition of AlCr-based coatings, powder metallurgically manufactured composite targets are used most commonly. Sputtering has the advantage that composite targets in the form of segmented targets or targets with plugs of a second type of material (e.g., Cr plugs in $\mathrm{Al}$ target plates) can also be used [48].

Modern coating systems run in fully automatic operation. They must fulfil the following criteria with respect to high productivity and quality: high production reliability, short cycle times, high flexibility in coating types and substrate holders, easy maintenance. Additional aspects are CE (Conformité Européenne), conformity and high occupational safety standards. Environmental sustainability is also gaining importance, including the influence of factors such as energy consumption.

Of course, the basic components of the coating systems must also be optimised, e.g., vacuum pumps, power supplies, particle sources, heaters, substrate holders. In addition, all process steps including loading, pumping, heating, ion cleaning, coating, cooling, unloading and maintenance must be optimised for short cycle times and efficient operation. The choice between batch systems or inline systems depends on the use and the required flexibility. Batch systems are predominant for industrial coating applications. The system size is selected based on the expected batch size as determined by the dimensions and number of parts to be coated, but also by operating economy.

The usable volume of a batch system is defined by the interior size of the deposition chamber. Usually, coating systems are designed with a circular geometry along a central axis, allowing the rotation of substrates. The maximum useful volume therefore constitutes a cylindrical body. Small coating systems typically have a diameter of $<0.5 \mathrm{~m}$ and a height of $<0.5 \mathrm{~m}$, which is adequate for small-scale series or research facilities. Medium size systems, with roughly a diameter of $1 \mathrm{~m}$ and a height of $1 \mathrm{~m}$, are predominant in industrial production. Figure 2 shows an arc system equipped with circular arc evaporators, and a coatable diameter of $0.7 \mathrm{~m}$ and a height of $0.9 \mathrm{~m}$. Special-purpose systems are available for large-scale manufacturing, with roughly a diameter of $1.5 \mathrm{~m}$ and a height of $1.5 \mathrm{~m}$. Systems for oversized parts, such as broaches or plastic extrusion screws, have a coating height of up to $4.5 \mathrm{~m}$. 


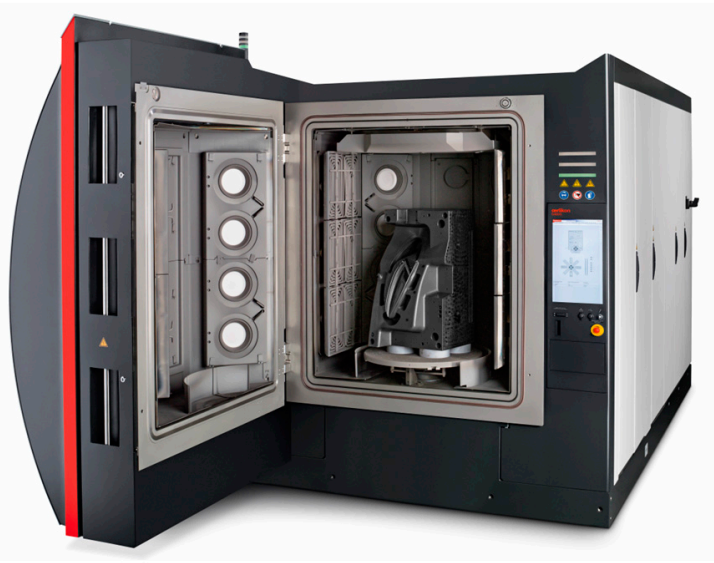

Figure 2. Medium-sized arc system equipped with circular arc evaporators, diameter $0.7 \mathrm{~m}$, height $0.9 \mathrm{~m}$, courtesy of Oerlikon Balzers.

\section{Basic Properties of CrAlN and AlCrN Coatings}

CrAl-based and AlCr-based coatings deposited by arc evaporation processes or by magnetron sputtering are widely used for cutting tools, moulds, dies and for various components. The success of these coatings with their predominantly fcc structure is due to their outstanding mechanical and tribological properties (such as high hot hardness, good abrasive and sliding wear resistance) combined with high oxidation and corrosion resistance. The present chapter highlights selected basic coating properties.

To begin with, an important remark must be made on the way the coating composition is reported in papers. A full compositional characterisation, including metallic and nonmetallic elements as well as impurities such as oxygen, is the most complete, but is not always reported. Several publications neglect the stoichiometric aspects, the deviation of coating composition from the cathode/target composition, and the incorporation of residual gas components. Sometimes, only the cathode/target composition or only one of the values $\mathrm{Al} / \mathrm{Cr}$ or $\mathrm{Al} /(\mathrm{Al}+\mathrm{Cr})$ are given, presumably because methods such as EDS are most suited for the characterisation of metallic and heavy elements. Many papers state that the coatings consist stoichiometrically of 50 at.\% metallic and 50 at.\% non-metallic elements, and they are simply described as $\left(\mathrm{Al}_{1-x} \mathrm{Cr}_{x}\right) \mathrm{N}$.

One positive example is described for arc-deposited coatings using cathodes of $\mathrm{Al}_{70} \mathrm{Cr}_{30}$. The coating was characterised by XPS as having $\mathrm{Al} 33.1$ at. $\%, \mathrm{Cr} 15.8$ at.\%, N 48.1 at.\%, and O 3.0 at.\%. The metallic content is thus 48.9 at.\% and the non-metallic content is 51.1 at. $\%$. The ratio $\mathrm{Al} /(\mathrm{Al}+\mathrm{Cr})$ is 0.68 , meaning 68 at.\% of the metallic content is $\mathrm{Al}$. This corresponds to a deviation of 2 at. \% from the cathode material. The $\mathrm{Al} / \mathrm{Cr}$ ratio in the coating is 2.09. The coating contains oxygen from the residual gas. The coating is slightly over-stoichiometric [58]. The total formula has to be $\left(\mathrm{Al}_{1-x} \mathrm{Cr}_{x}\right)\left(\mathrm{N}_{1-w} \mathrm{O}_{w}\right)$ plus the stochiometric ratio $\left(\mathrm{Al}_{1-x} \mathrm{Cr}_{x}\right) /\left(\mathrm{N}_{1-w} \mathrm{O}_{w}\right)$. Unfortunately, however, detailed compositional data are not reported in many publications.

As a guide for the reading of coating compositions, the following terminology is used throughout this paper.

1. If only the cathode composition is given and the stoichiometry in the coating is assumed to be equivalent to the cathode composition, the coating is described as $\left(\mathrm{Al}_{(100-x)} \mathrm{Cr}_{x}\right) \mathrm{N}$ with 100 in at. $\%$, e.g., $(\mathrm{Al} 70 \mathrm{Cr} 30) \mathrm{N}$.

2. If the metallic elements (and metalloids) were measured, but only a general statement about the stoichiometry is made, the coatings are described as $\left(\mathrm{Al}_{(100-x)} \mathrm{C}_{x}\right) \mathrm{N}$ with 100 in at.\%, e.g., $\left(\mathrm{Al}_{70} \mathrm{Cr}_{30}\right) \mathrm{N}$.

3. If both metallic elements (and metalloids) and the $\mathrm{N}, \mathrm{O}$ (and $\mathrm{C}$ ) content were measured, all values are given as $\mathrm{Al}_{x} \mathrm{Cr}_{y} \mathrm{~N}_{u} \mathrm{O}_{w}$, where $x+y+u+w=100$ at.\%, e.g., $\mathrm{Al}_{33} \mathrm{Cr}_{16} \mathrm{~N}_{48} \mathrm{O}_{3}$. 


\subsection{The Influence of Al Content on Lattice Parameters, Phases and Microhardness}

A schematic diagram of different basic crystal structures as a function of the Al portion of the coating's metallic content in at.\% is shown in Figure 3. It should be mentioned that in publications, the formula $\mathrm{Cr}_{1-x} \mathrm{Al}_{x} \mathrm{~N}$ or $\mathrm{Al}_{1-x} \mathrm{Cr}_{x} \mathrm{~N}$ is sometimes used for the same coating in dependence on the $\mathrm{Al}$ content. Nowadays, the most commonly used terminology in industrial applications is the short name $(\mathrm{AlCr}) \mathrm{N}$ for $\mathrm{Al}$-rich coatings. The authors suggest that coatings with a chemical composition in at.\% of $\mathrm{Cr}>\mathrm{Al}$ should be named $(\mathrm{CrAl}) \mathrm{N}$. If $\mathrm{Al}>\mathrm{Cr}$, then the coating should be named $(\mathrm{AlCr}) \mathrm{N}$. $(\mathrm{CrAl}) \mathrm{N}$ coatings always have an fcc crystal structure. This structure type is also referred to as $\mathrm{B} 1$, a $\mathrm{NaCl}$ structure or $\mathrm{c}$ in certain publications, depending on the convention. With increasing $\mathrm{Al}$ content, a phase evolution to an hcp crystal structure takes place, which is also referred to as B4, a ZnS-type structure, wurtzite, w, h or hcp in publications. In the following, fcc and hcp will be used.

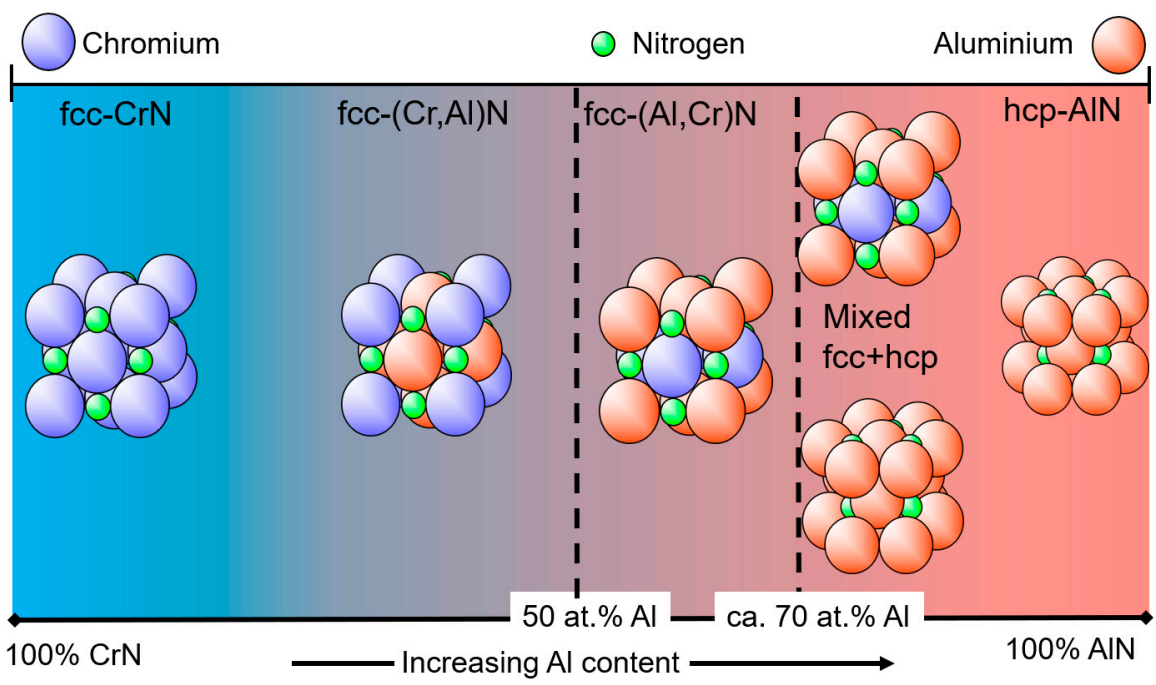

Figure 3. Schematic diagram showing the basic crystal structure of $(\mathrm{CrAl}) \mathrm{N}$ and $(\mathrm{AlCr}) \mathrm{N}$ coatings as a function of the $\mathrm{Al}$ content.

XRD investigations of rf-sputtered coatings have shown that at 57 at.\% $\mathrm{Al}$, a pure fcc structure was obtained, while at 75 at. $\% \mathrm{Al}$, the hcp structure was observed. The transition range between $\mathrm{fcc}$ and $\mathrm{fcc}+\mathrm{hcp}$ was in the range of 57 at. $\%<\mathrm{Al}_{\max }<67$ at.\% [49]. With pulsed closed-field magnetron sputtering, the formation of hcp phases was observed at an $\mathrm{Al}$ content of 64 at. $\%$, whereas fcc phases were detected at up to 60.9 at. $\%$, giving a transition range of 60.9 at.\% $<\mathrm{Al}_{\max }<64$ at.\% [59]. A systematic experimental investigation of $(\mathrm{CrAl}) \mathrm{N}$ and $(\mathrm{AlCr}) \mathrm{N}$ coatings synthesised using the cathodic arc method showed that the crystal structure changed from a pure fcc structure to a mixed-phase structure of fcc and hcp at an $\mathrm{Al}$ content of about 60-70 at.\% of the metal content in the cathodes [60], whereas an fcc structure was observed at up to 71 at.\% in the coating by the authors of [61].

The reported different maximum $\mathrm{Al}$ contents for the X-ray-diffraction-measured pure fcc phase differ over a range of about 60-70 at.\%, as shown in Table 1. 
Table 1. Maximum Al content for pure fcc phase generation measured by X-ray diffraction for arc-deposited and sputtered coatings.

\begin{tabular}{|c|c|c|c|c|c|}
\hline Deposition Method & $\begin{array}{l}\text { Source Composition } \\
\text { (Targets/Cathodes) }\end{array}$ & $\begin{array}{c}\text { Pure fcc Phases by X-Ray at Al } \\
\text { [at.\%] Coating or Source }\end{array}$ & $\begin{array}{c}\text { Fcc }+ \text { hcp Phases by X-Ray at Al } \\
\text { [at. } \% \text { ] Coating or Source }\end{array}$ & $\begin{array}{l}\text { Range of Transition } \\
\quad \mathrm{Al}_{\max }[\text { at. } \%]\end{array}$ & Reference \\
\hline RF sputtering & $\mathrm{Al}$ and $\mathrm{Cr}$ targets & $\begin{array}{c}\text { Coating } \\
57 \text { at } \mathrm{RT} \\
56 \text { at } 300{ }^{\circ} \mathrm{C}\end{array}$ & $\begin{array}{c}\text { Coating } \\
75 \text { at } \mathrm{RT} \\
67 \text { at } 300{ }^{\circ} \mathrm{C}\end{array}$ & $\begin{array}{c}\text { Coating } \\
57<\mathrm{Al}_{\max }<67\end{array}$ & [49] \\
\hline RF/DC sputtering & $\mathrm{Al}$ and $\mathrm{Cr}$ targets & $\begin{array}{c}\text { Coating } \\
63 \text { at } 300^{\circ} \mathrm{C}\end{array}$ & - & $63<\mathrm{Al}_{\max }$ & [51] \\
\hline $\begin{array}{l}\text { Pulsed CFUBM } \\
\text { sputtering }\end{array}$ & $\begin{array}{c}\mathrm{Al} \text { and } \mathrm{Cr} \\
\text { targets }\end{array}$ & $\begin{array}{c}\text { Coating } \\
60.9 \text { at } 175^{\circ} \mathrm{C}\end{array}$ & $\begin{array}{c}\text { Coating } \\
64 \text { at } 175^{\circ} \mathrm{C}\end{array}$ & $\begin{array}{c}\text { Coating } \\
60.9<\mathrm{Al}_{\max }<64\end{array}$ & [59] \\
\hline Arc & Alloyed cathodes & $\begin{array}{l}\text { Cathodes } \\
60 \text { at } 600{ }^{\circ} \mathrm{C}\end{array}$ & $\begin{array}{c}\text { Cathodes } \\
70 \text { at } 600{ }^{\circ} \mathrm{C}\end{array}$ & $\begin{array}{c}\text { Cathodes } \\
60<\mathrm{Al}_{\max }<70\end{array}$ & {$[60]$} \\
\hline Arc & Alloyed cathodes & $\begin{array}{c}\text { Coating } \\
70 \text { at } 500{ }^{\circ} \mathrm{C} \\
\text { TEM traces hcp }\end{array}$ & - & $\begin{array}{l}\text { Coating } \\
70<\mathrm{Al}_{\max }\end{array}$ & {$[62]$} \\
\hline Arc & Alloyed cathodes & $\begin{array}{c}\text { Coating } \\
71 \text { at } 450{ }^{\circ} \mathrm{C}\end{array}$ & $\begin{array}{c}\text { Coating } \\
75 \text { at } 450{ }^{\circ} \mathrm{C}\end{array}$ & $\begin{array}{c}\text { Coating } \\
71<\mathrm{Al}_{\max }<83\end{array}$ & [61] \\
\hline DC sputtering & $\begin{array}{l}\text { Segmented } \\
\text { target }\end{array}$ & $\begin{array}{c}\text { Coating } \\
70 \text { at } 400{ }^{\circ} \mathrm{C}\end{array}$ & - & $\begin{array}{c}\text { Coating } \\
70<\mathrm{Al}_{\max }\end{array}$ & [64] \\
\hline DC sputtering & $\begin{array}{l}\text { Alloyed } \\
\text { targets }\end{array}$ & $\begin{array}{c}\text { Targets }{ }^{1} \\
70 \text { at } 500{ }^{\circ} \mathrm{C}\end{array}$ & - & $\begin{array}{c}\text { Targets } \\
70<\mathrm{Al}_{\max }\end{array}$ & [65] \\
\hline Arc & Alloyed cathodes & $\begin{array}{c}\text { Coating } \\
70 \text { at } 500{ }^{\circ} \mathrm{C}\end{array}$ & $\begin{array}{c}\text { Coating } \\
82 \text { at } 500{ }^{\circ} \mathrm{C}\end{array}$ & $\begin{array}{c}\text { Coating } \\
70<\mathrm{Al}_{\max }<82\end{array}$ & {$[66]$} \\
\hline
\end{tabular}

${ }^{1}$ source: no measurement of chemical composition in the coating, values from cathodes/targets. 
The deposition process itself (source properties, parameters) has an influence at the maximum Al concentration on whether a pure fcc phase is obtained using X-ray diffraction, as will be shown for arc evaporation in Section 3.4.

Taking measurement uncertainties into account, a well-accepted maximum critical value of the transition is about 70 at.\% $\mathrm{Al}$ [61-66]. It should be mentioned that coatings with Al contents of 65-70 at.\% might contain some traces of hcp phases, which may, however, be difficult to detect using XRD. For example, this effect was observed with SAED (Selected Area Electron Diffraction) measurement of ( $\mathrm{AlCr}$ ) N coatings deposited using arc evaporation from cathodes of $\mathrm{Al}_{70} \mathrm{Cr}_{30}$ on sapphire [62]. The critical value of the transition from fcc to the mixed fcc plus hcp structure also depends slightly on the deposition conditions, influenced, for example, by the evaporator magnetic field set-up analogously to AlTiN [9], but bias and deposition pressure also have an influence on the "fine" structure in the area of the transition [45].

Figure 4 shows experimental results for the hardness and lattice parameters of arcdeposited $(\mathrm{CrAl}) \mathrm{N}$ and $(\mathrm{AlCr}) \mathrm{N}$ coatings $[60,61]$. Both studies show a hardness increase of about $60 \%$ compared to $\mathrm{CrN}$ for fcc-structured coatings in the range of $\mathrm{Al} 60-70$ at. $\%$. The differences in the absolute values are likely related to different deposition techniques and hardness measurement conditions. Furthermore, in the region of the mixed-phase structure of $\mathrm{fcc}+$ hcp at high Al-content, the hardness is equivalent to $\mathrm{CrN}$. The lattice parameters decrease from $0.415-0.416 \mathrm{~nm}(\mathrm{CrN}))$ to $0.413 \mathrm{~nm}$ in the region of $\mathrm{Al} 60-70$ at.\%.

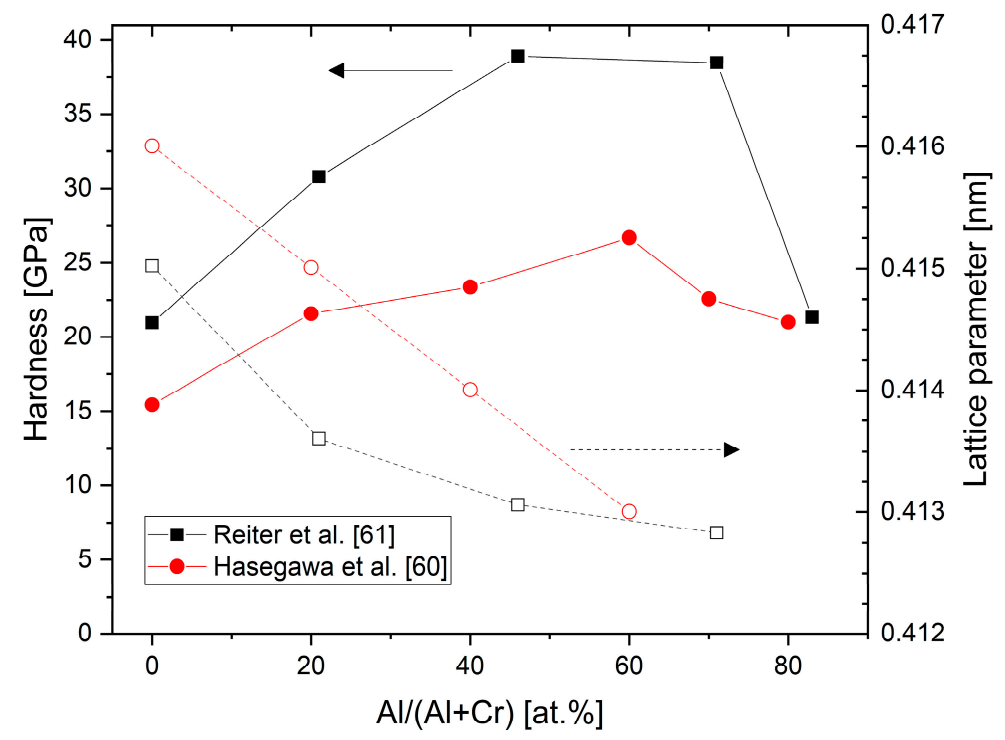

Figure 4. Hardness and lattice parameters of $(\mathrm{CrAl}) \mathrm{N}$ and $(\mathrm{AlCr}) \mathrm{N}$ coatings versus $\mathrm{Al}$ content deposited by cathodic vacuum arc, redrawn after [60,61], original (C) Elsevier.

Lattice parameters for $(\mathrm{CrAl}) \mathrm{N},(\mathrm{AlCr}) \mathrm{N}, \mathrm{CrN}$ and $\mathrm{AlN}$ coatings calculated ab initio are shown in Figure 5 and are compared with experimental XRD results [63]. The good fit of the calculated and the experimental data shows how well the basic properties of AlCr-based coatings can be calculated.

\subsection{Mechanical and Physical Properties}

\subsubsection{Thermal Expansion}

The thermal expansion coefficients (TECs) of fcc-structured $(\mathrm{Cr}, \mathrm{Al}) \mathrm{N}$ and $(\mathrm{Al}, \mathrm{Cr}) \mathrm{N}$ coatings deposited by sputtering were investigated using synchrotron $\mathrm{X}$-ray diffraction at up to $600^{\circ} \mathrm{C}$ [65]. It was shown that the thermal expansion coefficient increases with an increasing $\mathrm{Al}$ content, from about $7 \times 10^{-6} / \mathrm{K}$ at room temperature to $10 \times 10^{-6} / \mathrm{K}$ at $600{ }^{\circ} \mathrm{C}$, see Figure 6 . Higher mean values of $14.5 \times 10^{-6} / \mathrm{K}$ were reported both for sputtered and arc-deposited $\left(\mathrm{Al}_{70} \mathrm{Cr}_{30}\right) \mathrm{N}$ coatings at room temperature [43]. A fair general estimate is thus $(10.5 \pm 3.5) \times 10^{-6} / \mathrm{K}$. 


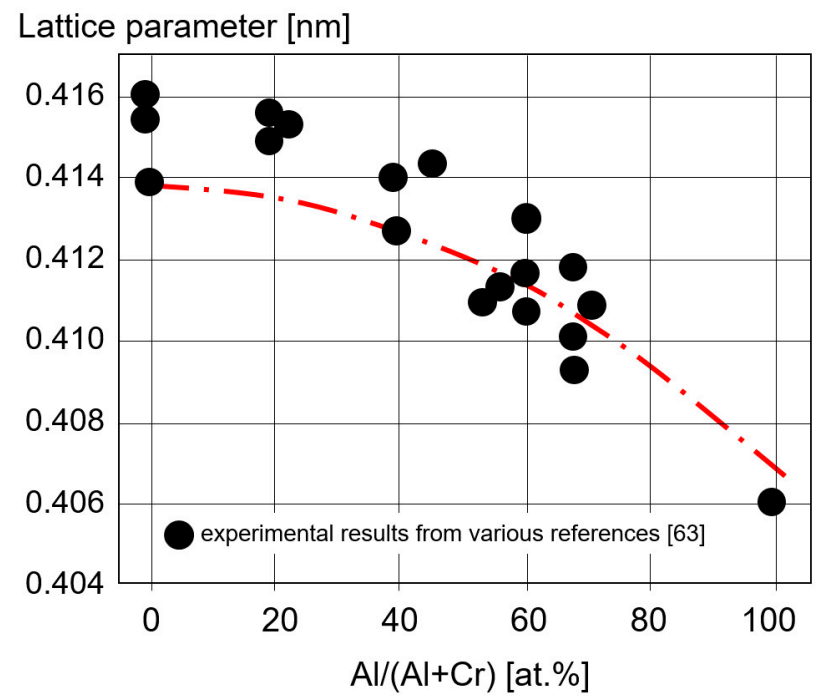

Figure 5. Lattice parameter calculated ab initio for $\mathrm{CrN},(\mathrm{CrAl}) \mathrm{N},(\mathrm{AlCr}) \mathrm{N}$, and $\mathrm{AlN}$ coatings and experimentally measured XRD values, redrawn after [63], original @ Elsevier.

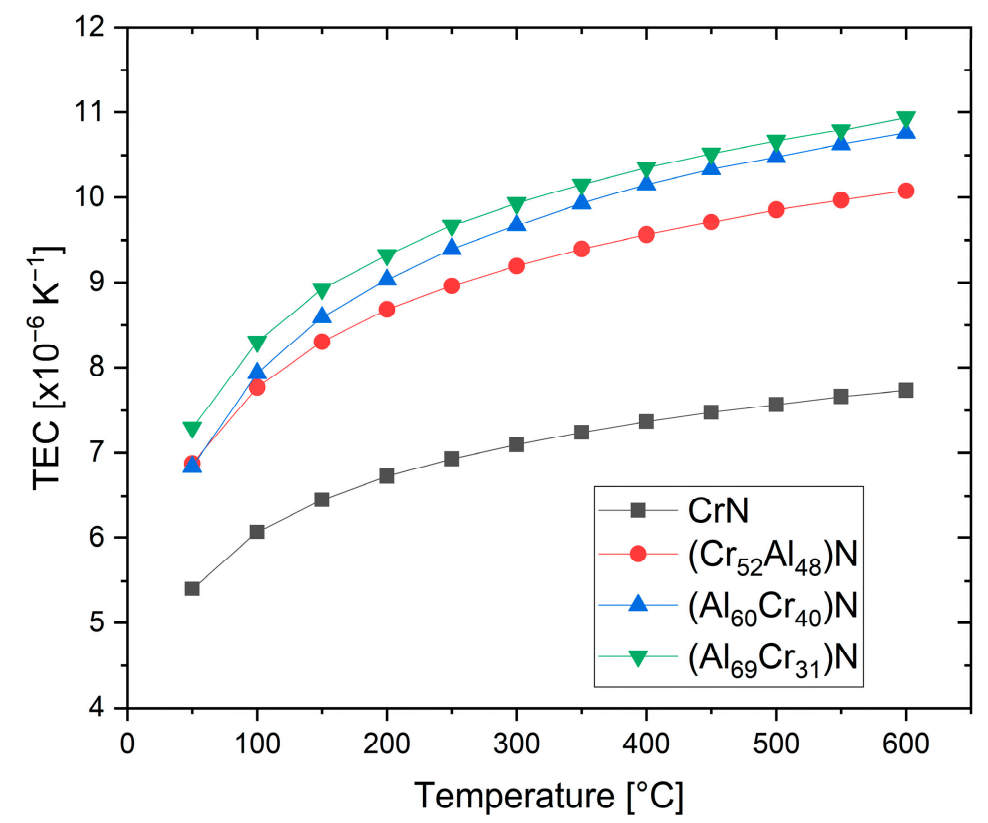

Figure 6. Temperature-dependent thermal expansion coefficients (TECs) of (CrAl)N and (AlCr)N coatings derived from synchrotron experiments, redrawn after [65], original @ Elsevier.

\subsubsection{Thermal Conductivity}

Figure 7 shows the thermal conductivity of $\left(\mathrm{Ti}_{50} \mathrm{Al}_{50}\right) \mathrm{N},\left(\mathrm{Al}_{66} \mathrm{Ti}_{34}\right) \mathrm{N}$, and $\left(\mathrm{Al}_{70} \mathrm{Cr}_{30}\right) \mathrm{N}$ coatings [67]. The thermal conductivity is temperature-dependent and it is interesting to note that the thermal conductivity of $\left(\mathrm{Al}_{70} \mathrm{Cr}_{30}\right) \mathrm{N}$ drops at about $200{ }^{\circ} \mathrm{C}$ and, in the temperature range of $250-450{ }^{\circ} \mathrm{C}$, is significantly lower than that of $\left(\mathrm{Al}_{66} \mathrm{Ti}_{34}\right) \mathrm{N}$. The thermal properties of $\mathrm{Cr}_{25} \mathrm{Al}_{20.5} \mathrm{Si}_{4.5} \mathrm{~N}_{50}$ coatings were measured using pulsed photothermal radiometry. A very low thermal conductivity of ca. $2.75 \mathrm{~W} / \mathrm{mK}$ at room temperature and $3.5 \mathrm{~W} / \mathrm{mK}$ at $400{ }^{\circ} \mathrm{C}$ was found [68]. PVD coatings exhibit a certain anisotropy of thermal conductivity perpendicular and parallel to the direction of growth. This effect is particularly pronounced for multilayer coatings. When engineering the thermal properties of a coated part, not only the intrinsic thermal conductivity of the coatings, but also the concentration and dimension of different growth defects, e.g., holes and droplets, must be taken into account [69]. 


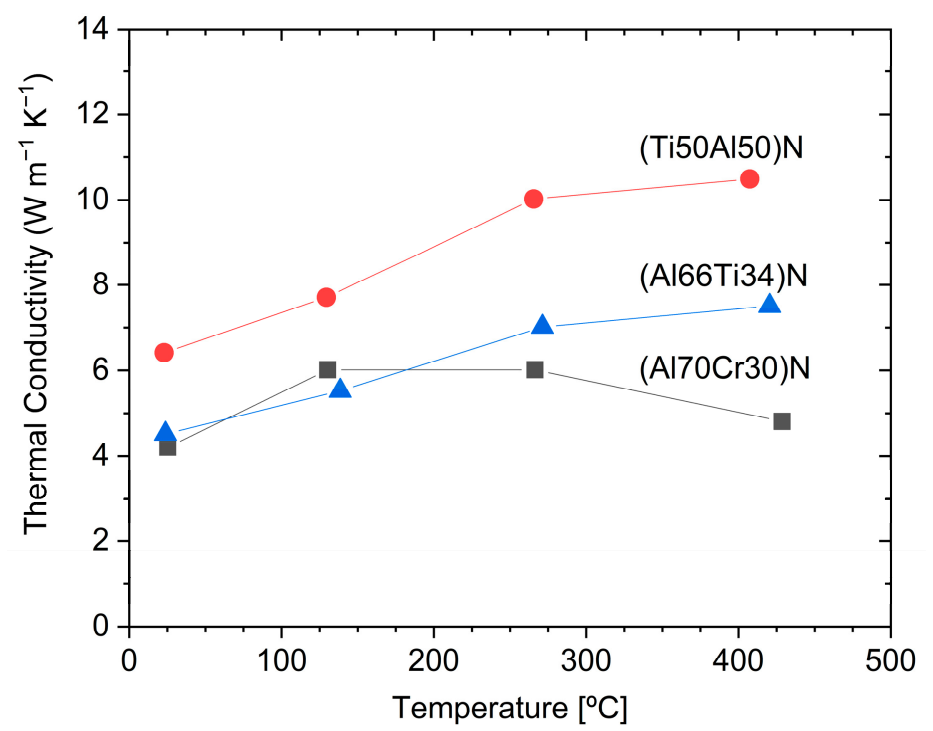

Figure 7. The temperature dependence of thermal conductivity for arc-deposited $\left(\mathrm{Ti}_{50} \mathrm{Al}_{50}\right) \mathrm{N}$, $\left(\mathrm{Al}_{66} \mathrm{Ti}_{34}\right) \mathrm{N}$ and $\left(\mathrm{Al}_{70} \mathrm{Cr}_{30}\right) \mathrm{N}$ coatings, measured using the picosecond thermal reflection method, redrawn after [67], original @ Elsevier.

\subsubsection{Electrical Resistivity}

A two-probe measurement method was used to estimate the surface resistance as a function of the $\mathrm{Al} /(\mathrm{Al}+\mathrm{Cr})$ ratio for arc-deposited coatings. It can be seen in Figure 8 that the electrical resistivity increases sharply with the $\mathrm{Al}$ portion of the metallic content in at.\% [19].

\section{Surface resistance}

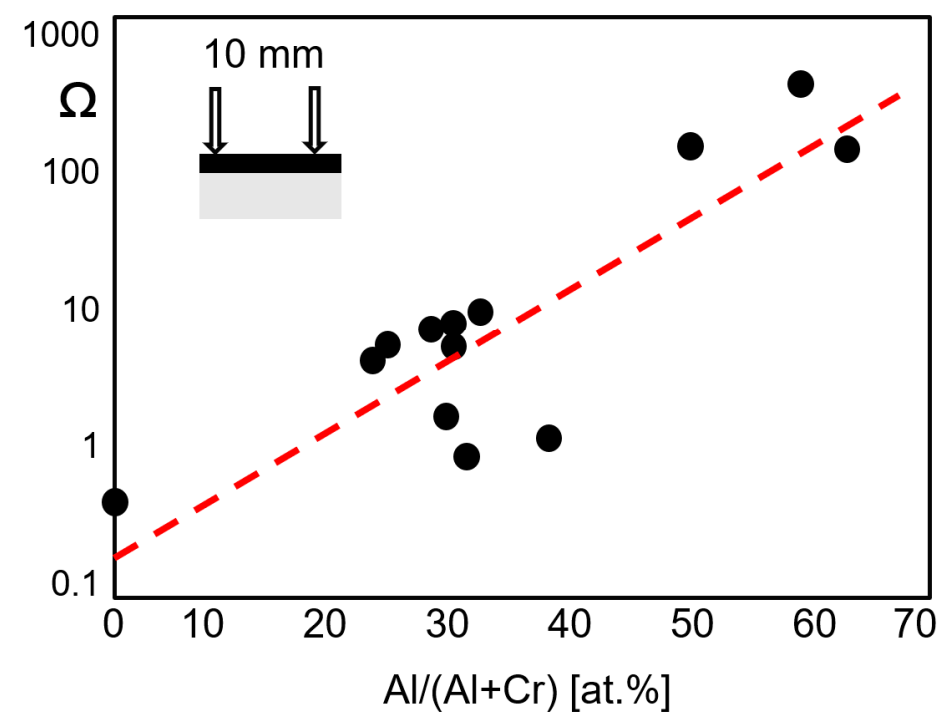

Figure 8. Surface resistance as a function of the $\mathrm{Al}$ content of $\mathrm{fcc}-(\mathrm{Cr}, \mathrm{Al}) \mathrm{N}$ and fcc- $(\mathrm{Al}, \mathrm{Cr}) \mathrm{N}$ arcdeposited coatings, redrawn after [19], original @ Elsevier.

\subsubsection{Poisson's Ratio, Young's Moduli, Fracture Toughness}

$\mathrm{Ab}$ initio calculations have shown that the Poisson's ratio drops from about 0.27 for low $\mathrm{Al}$ contents to about 0.2 for an $\mathrm{Al}$ content of 70 at.\% [70]. Figure 9 shows the ab initio calculated Young's moduli (E) as a function of the $\mathrm{Al}$ content for fcc (Al, Cr)N [70,71]. Selected Young's moduli measured by nanoindentation from [64,71] have been added. 


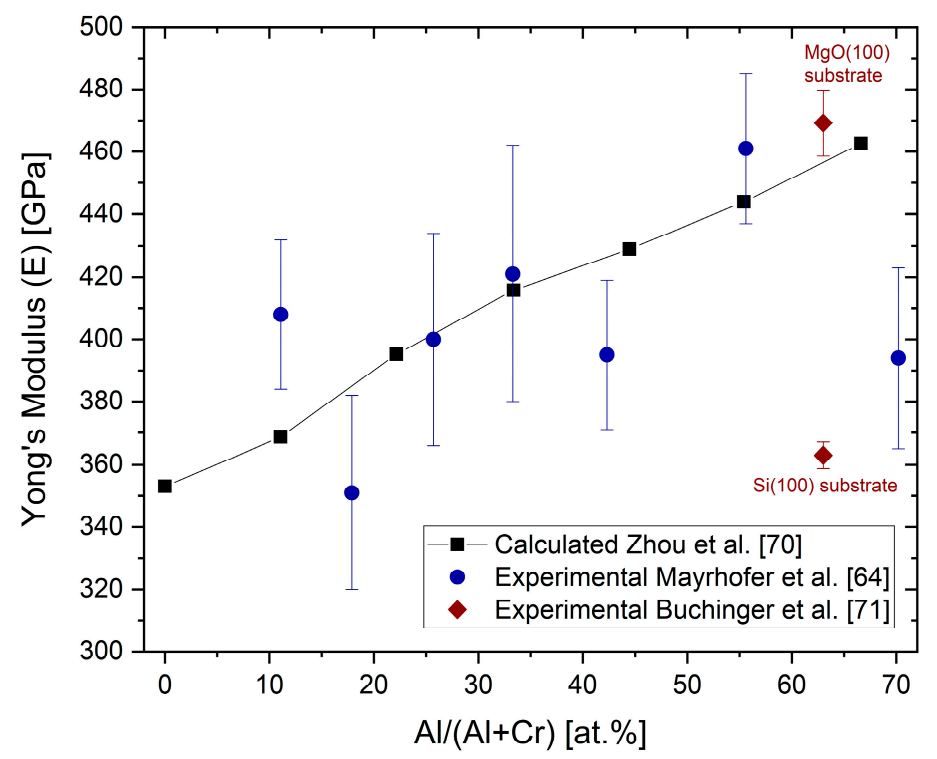

Figure 9. Ab initio calculated Young's moduli $\mathrm{E}$ and experimentally obtained indentation moduli (black symbols) for different $\mathrm{Al}$ concentrations in $\mathrm{fcc}-(\mathrm{Cr}, \mathrm{Al}) \mathrm{N}$ and $\mathrm{fcc}-(\mathrm{Al}, \mathrm{Cr}) \mathrm{N}$ coatings, redrawn after [70], original @ AIP Publishing, data from [64,71].

The Young's modulus increases with an increasing $\mathrm{Al}$ content. The same relative tendency, but with lower absolute values, was experimentally shown in [43]. The calculated values are in good agreement with measured nanoindentation moduli [64,72]. The Young's modulus of ( $\mathrm{AlCr}) \mathrm{N}$ coatings drops significantly when the mixed-phase structure fcc + hcp is reached [43], as well as for Si-alloyed ( $\mathrm{AlCr}) \mathrm{N}$ coatings of, for example, $\mathrm{Al}_{33.4} \mathrm{Cr}_{18.3} \mathrm{Si}_{2.3} \mathrm{~N}_{46} \mathrm{O}_{0.7}$ [73]. It should be noted that large variations of measured $\mathrm{E}$ values for fcc- $(\mathrm{Al}, \mathrm{Cr}) \mathrm{N}$ coatings have been published for coatings of nearly the same composition, for example, from $300 \mathrm{GPa}(\mathrm{Al} /(\mathrm{Al}+\mathrm{Cr})$ content of 68 at.\%) [73] to $469 \mathrm{GPa}(\mathrm{Al} /(\mathrm{Al}+$ $\mathrm{Cr}$ ) content of 63 at.\%) [71]. Different sample conditions (thickness and substrate) and measurement systems themselves will influence the measured value.

In addition to the chemical composition, the Young's modulus is also dependent on the grain size (grain boundary fraction), the compressive stress state, and the texture. A variation from 363 to $469 \mathrm{GPa}$ was measured for $\mathrm{Al}_{28.4} \mathrm{Cr}_{18.6} \mathrm{~N}_{55}$ in different coating states. The high value was measured for a highly 100 -oriented coating deposited on $\mathrm{MgO}$ (100) substrates [71]. Thus, a relatively wide variation of experimental results, besides the measuring conditions, must be anticipated.

The fracture toughness $\mathrm{K}_{\mathrm{IC}}$ of sputtered $\mathrm{Al}_{28.4} \mathrm{Cr}_{18.6} \mathrm{~N}_{55}$ was measured by micromechanical bending tests at $1.3 \pm 0.1 \mathrm{MPa} \sqrt{ } \mathrm{m}$, which is lower than that of TiN at $2.0 \pm 0.1$ $\mathrm{MPa} \sqrt{ } \mathrm{m}$ related to domain size effects, but it is possible to raise this in a superlattice combination of the two materials [71].

\subsubsection{Thermal Phase Stability and Hardness after Annealing}

The thermal stability of arc-deposited $(\mathrm{CrAl}) \mathrm{N}$ and $(\mathrm{AlCr}) \mathrm{N}$ coatings has been investigated through heat treatment in an Ar atmosphere with a hold time of $2 \mathrm{~h}$ at temperatures between 600 and $1300{ }^{\circ} \mathrm{C}$ in combination with XRD analysis [61]. The fcc structure was found to be stable up to $800^{\circ} \mathrm{C}$. Three reactions were observed sequentially for the ( $\left.\mathrm{AlCr}\right) \mathrm{N}$ system:

1. Transformation of fcc $(\mathrm{Al}, \mathrm{Cr}) \mathrm{N}$ to hcp $(\mathrm{Al}, \mathrm{Cr}) \mathrm{N}$ at the grain boundaries first [74],

2. Segregation of $\mathrm{Cr}_{2} \mathrm{~N}$,

3. Segregation of pure chromium.

Above $900{ }^{\circ} \mathrm{C}$, the entire coating transforms to a mixed-phase structure. No phase transformation occurred in the hcp-AlN coatings, as they were already in their thermodynamically stable state. This is shown schematically in Figure 10. 


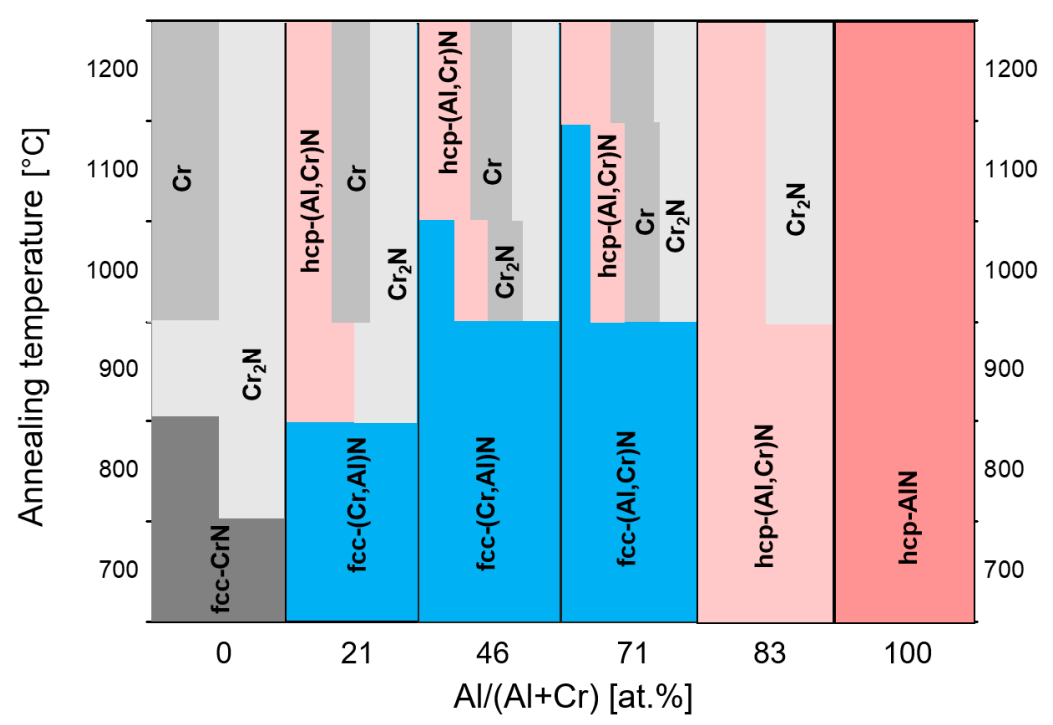

Figure 10. Schematic diagram of phase stability for $(\mathrm{CrAl}) \mathrm{N}$ and $(\mathrm{AlCr}) \mathrm{N}$ as determined by XRD spectra after annealing at different temperatures, redrawn after [61], original @ Elsevier.

The effect of the annealing on the hardness of the same coatings was characterised as well, see Figure 11.

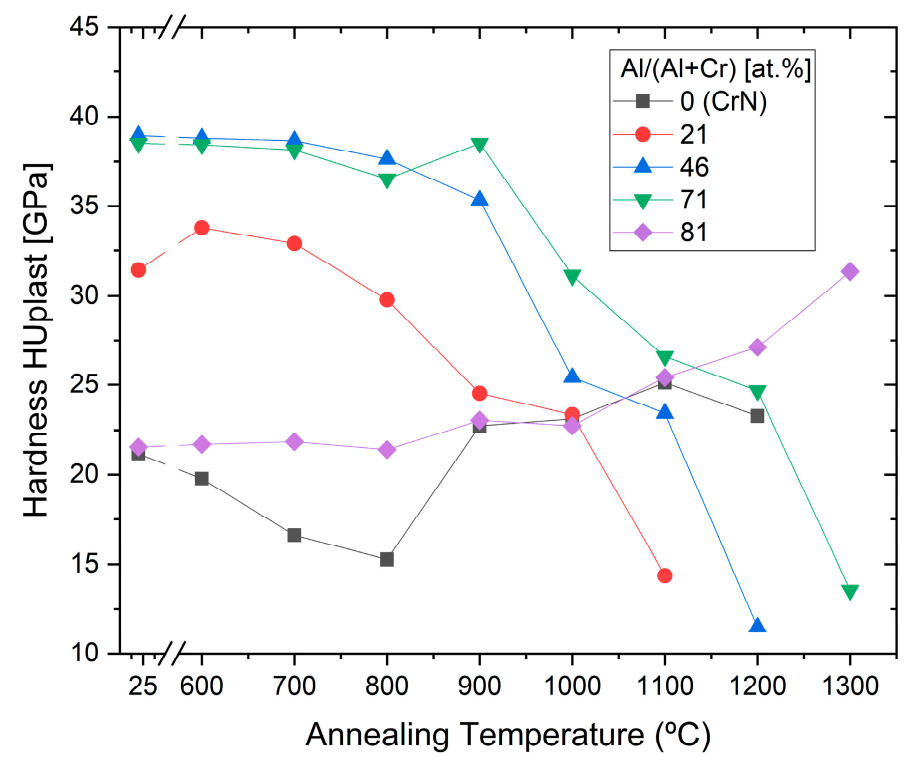

Figure 11. Microhardness for $(\mathrm{CrAl}) \mathrm{N},(\mathrm{AlCr}) \mathrm{N}, \mathrm{CrN}$ and $\mathrm{AlN}$ coatings after annealing at different temperatures, redrawn after [61], original @ Elsevier.

The highest hardness was shown for $\left(\mathrm{Cr}_{54} \mathrm{Al}_{46}\right) \mathrm{N}$ and $\left(\mathrm{Al}_{71} \mathrm{Cr}_{29}\right) \mathrm{N}$, and was retained up to 800 and $900{ }^{\circ} \mathrm{C}$, respectively. The subsequent drop in hardness at higher annealing temperatures is correlated with the phase decomposition [61].

The influence of the coating stress at the decomposition temperature was investigated by varying the deposition temperature. The coating deposition was performed by arc using $\mathrm{Al}_{70} \mathrm{Cr}_{30}$ cathodes. It was shown that the decomposition temperatures of the metastable fcc- $\left(\mathrm{Al}_{63.5} \mathrm{Cr}_{36.5}\right) \mathrm{N}$ phase depends significantly on the stress level in the coatings. The decomposition process starts at the same compressive stress level of around 4.3 GPa for all coatings that were investigated [75].

Figure 12 shows a comparison of the hardness after annealing at high temperatures for different commercial hard coatings, showing that the $\left(\mathrm{Al}_{70} \mathrm{Cr}_{30}\right) \mathrm{N}$ coating has the highest hot hardness for temperatures exceeding $950{ }^{\circ} \mathrm{C}$. 


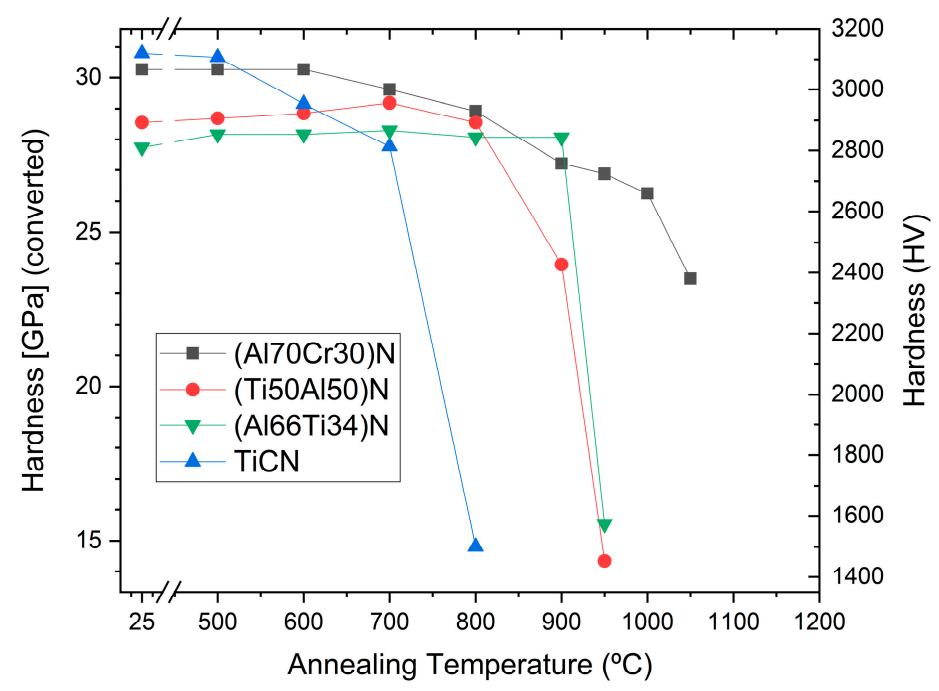

Figure 12. Hardness after annealing of commercial TiCN, $\left(\mathrm{Ti}_{50} \mathrm{Al}_{50}\right) \mathrm{N},\left(\mathrm{Al}_{66} \mathrm{Ti}_{34}\right) \mathrm{N}$ and $\left(\mathrm{Al}_{70} \mathrm{Cr}_{30}\right) \mathrm{N}$ coatings on cemented carbide.

\subsubsection{Oxidation Behaviour}

The oxidation behaviour of PVD hard coatings is an important property for applications such as dry high speed cutting and high temperature stressed components such as turbochargers. In a study of $\mathrm{Cr}$-rich $(\mathrm{CrAl}) \mathrm{N}$ sputtered coatings $(\mathrm{Cr} / \mathrm{Al}=2.94)$, a relatively small $\mathrm{Al}$ content $\left(\mathrm{Cr}_{44} \mathrm{Al}_{15} \mathrm{~N}_{40}\right.$ at.\%) improved the oxidation stability compared to $\mathrm{CrN}$ [15]. The first publication about the oxidation characteristics of arc-deposited coatings ( $\mathrm{AlCr}$ ) N with a $\mathrm{Al} / \mathrm{Cr}$ ratio $>0.5$ showed a lower oxidation rate in comparison with $\mathrm{CrN}$ [19], as has been confirmed in further studies [51,61,76,77]. Oxidation tests of (CrAl)N and (AlCr)N coatings deposited by activated reactive evaporation showed excellent behaviour [32]. The authors stated that the investigated $(\mathrm{CrAl}) \mathrm{N}$ and $(\mathrm{AlCr}) \mathrm{N}$ coatings exhibited significantly better oxidation behaviour than TiAlN coatings, which has been confirmed in further studies [40,78]. A systematic comparison of the oxidation behaviour of arc-deposited (AlTi)N and $(\mathrm{AlCr}) \mathrm{N}$ coatings, including long time exposure, was performed in [40]. It was shown that the oxidation resistance of both coatings improved with an increase in the $\mathrm{Al}$ content. The oxidation resistance of $(\mathrm{AlCr}) \mathrm{N}$ coatings was significantly superior to that of (AlTi)N coatings. Figure 13 shows the oxide layer thickness of $\mathrm{CrN},(\mathrm{CrAl}) \mathrm{N}$ and $(\mathrm{AlCr}) \mathrm{N}$ coatings after annealing in the temperature range of 800 to $1000^{\circ} \mathrm{C}$ in an ambient atmosphere for $30 \mathrm{~min}$ in 50 and $100{ }^{\circ} \mathrm{C}$ intervals. The addition of $20 \mathrm{at} . \%$ of $\mathrm{Al}$ to $\mathrm{CrN}$ deferred the start of oxidation by $100{ }^{\circ} \mathrm{C}$ and reduced the oxidation rate. The onset temperature for oxidation increased and the oxidation rate decreased with a further increase in the Al-content up to 71 at.\% Al. At a higher $\mathrm{Al}$ content, significantly decreased oxidation resistance was detected for a coating with 83 at. $\% \mathrm{Al}$ and for AlN. Oxidation then starts already at $800{ }^{\circ} \mathrm{C}$. These coatings already have an hcp structure. The negative influence of the hcp structure on the oxidation resistance was confirmed by [79].

A model of the oxidation behaviour for both the onset temperature and the oxidation rate depends on the coating composition and the related phase structure, as described above. However, it was observed in general that $\mathrm{Cr}$ and $\mathrm{Al}$ ions diffuse to the surface, forming a dense oxide layer acting as a diffusion barrier, thereby limiting the inward diffusion of oxygen $[32,76,80]$. The onset of oxidation of fcc $(\mathrm{Cr}, \mathrm{Al}) \mathrm{N}$ and fcc $(\mathrm{Al}, \mathrm{Cr}) \mathrm{N}$ always starts with the dissociation to $\mathrm{h}-\mathrm{Cr}_{2} \mathrm{~N}$ and nitrogen in the coating. The presence of thermally stable $\mathrm{Al}-\mathrm{N}$ bonding in the fcc- $(\mathrm{Cr}, \mathrm{Al}) \mathrm{N}$ structure can suppress the reduction of nitrogen in the coating. A dense $(\mathrm{CrAl})_{2} \mathrm{O}_{3}$ or $(\mathrm{AlCr})_{2} \mathrm{O}_{3}$ oxide layer (either amorphous or crystalline) is formed at an early stage of oxidation [76]. This can act as an effective diffusion barrier hindering the inward diffusion of the oxygen. All further reactions are influenced by the $\mathrm{Al}$ content at a given temperature. 


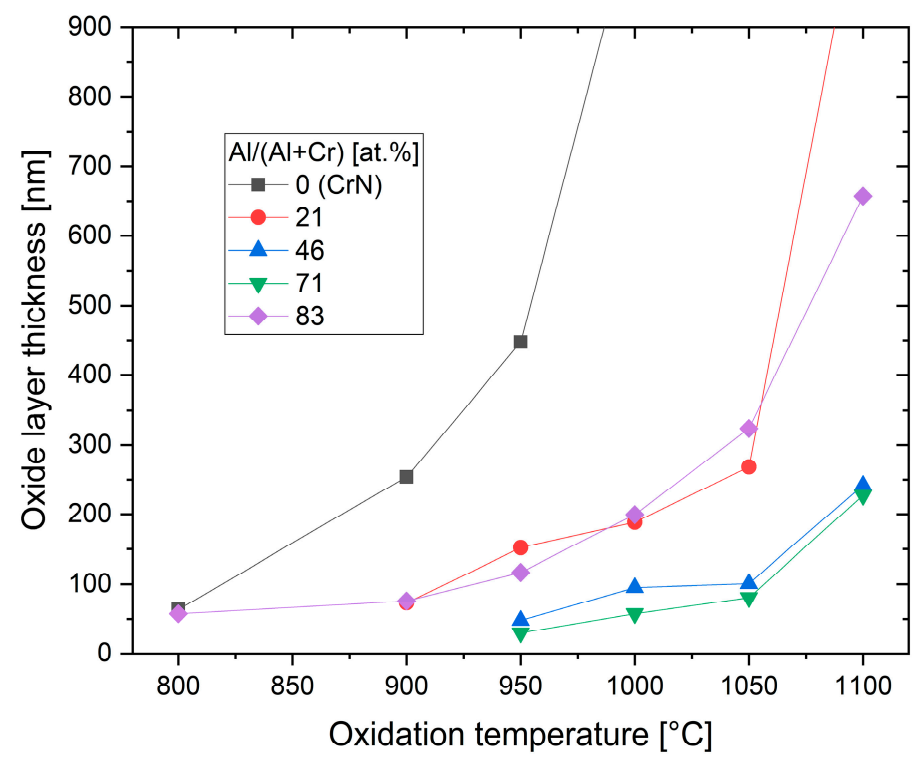

Figure 13. Thickness of oxide layer for $\mathrm{CrN},(\mathrm{CrAl}) \mathrm{N}$ and $(\mathrm{AlCr}) \mathrm{N}$ coatings after annealing at different temperatures in an air atmosphere, redrawn after [61], original @ Elsevier.

It should be mentioned that there are several ways to increase the oxidation stability of $(\mathrm{CrAl}) \mathrm{N}$ and $(\mathrm{AlCr}) \mathrm{N}$ coatings, e.g., by means of synergistic alloying of the coatings with small amounts of $\mathrm{Si}$ [81], see also Section 4.4. By way of illustration, Figure 14 shows the excellent oxidation resistance of $\left(\mathrm{Al}_{70} \mathrm{Cr}_{30}\right) \mathrm{N}$ coatings in comparison to industrial-standard PVD coatings.

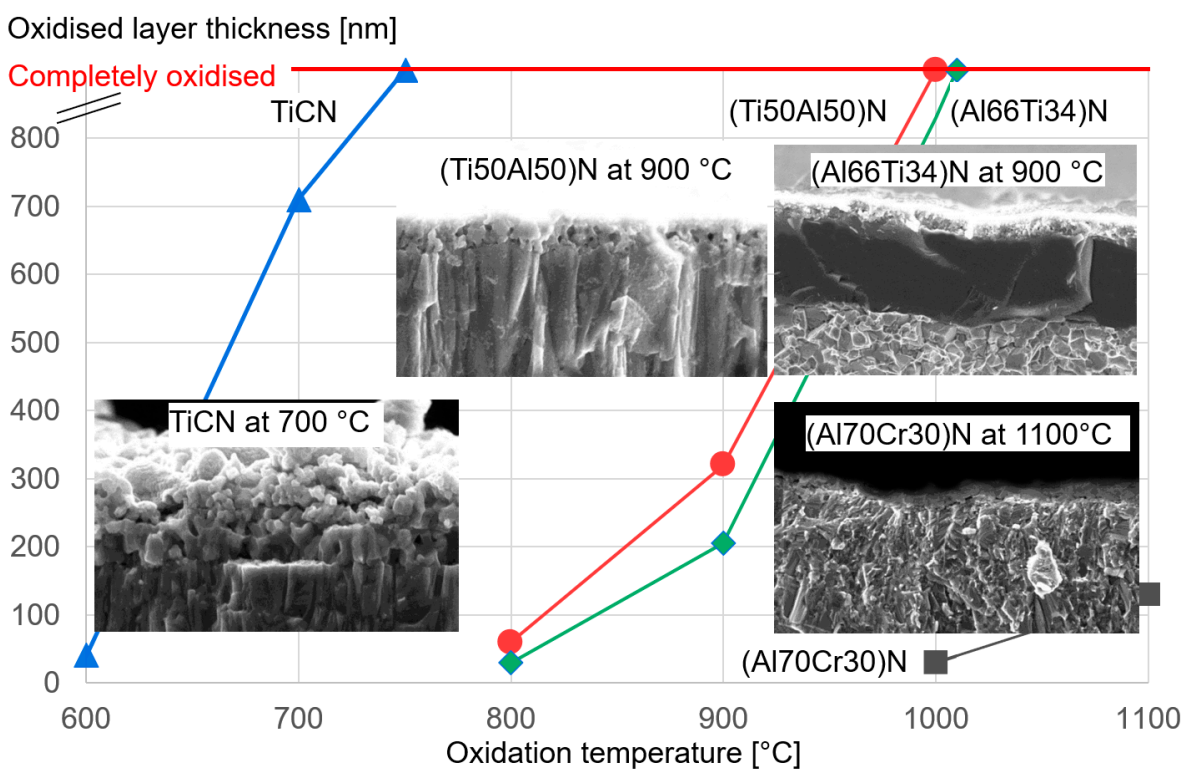

Figure 14. Thickness of the oxide layer as a function of the oxidation temperature for different industrial-standard PVD coatings.

\subsection{Selected Tribological Properties}

The tribological properties of $(\mathrm{CrAl}) \mathrm{N}$ and $(\mathrm{AlCr}) \mathrm{N}$ depend not only on the coating properties, but also on the tribosystem itself (e.g., counterpart, lubrication, temperature, loads). 


\subsubsection{Dry Friction against Steel}

The dry friction value of $(\mathrm{AlCr}) \mathrm{N}$ coatings against steel is slightly higher than that of $\mathrm{CrN}$ at ca. 0.65 [19], as measured using the pin-on-disc method against hardened bearing steel, 100Cr6. A friction value for (AlCr)N of about 0.5 was reported for AISI4340 as a pin [82]. The friction value at low load $(5 \mathrm{~N})$ was similar to that of $(\mathrm{TiAl}) \mathrm{N}$, whereas at high load conditions $(20 \mathrm{~N}),(\mathrm{AlCr}) \mathrm{N}$ displayed a significantly lower friction coefficient. The superior tribological behaviour, namely a low wear rate and low friction, of an $(\mathrm{AlCr}) \mathrm{N}$ coating against AISI 4340 steel is associated with the higher proportion of distinct (dispersive-polar) interactions, as evidenced by the measured surface energies. $(\mathrm{AlCr}) \mathrm{N}$ and $(\mathrm{TiAl}) \mathrm{N}$ coatings have a high polar component of 19.8 and $15.4 \mathrm{~mJ} / \mathrm{m}^{2}$, and a low dispersive component of 2.9 and $6.5 \mathrm{~mJ} / \mathrm{m}^{2}$, respectively, while the AISI 4340 steel presented a similar proportion between the polar, $14.3 \mathrm{~mJ} / \mathrm{m}^{2}$ and dispersive $13.5 \mathrm{~mJ} / \mathrm{m}^{2}$ components [82]. Measurement of the dry friction of $(\mathrm{AlCr}) \mathrm{N}$ coatings by pin-on-disc against austenitic stainless steel (DIN1.4301, AISI 304, hardness 274 HV1) showed a friction value of 0.85 at room temperature, which dropped to about 0.6 at higher temperatures [83].

\subsubsection{Dry Friction and Wear against Ceramics}

The coefficient of friction measured by pin-on-disc tests against $\mathrm{Al}_{2} \mathrm{O}_{3}$ balls for $(\mathrm{CrAl}) \mathrm{N}$ and $(\mathrm{AlCr}) \mathrm{N}$ coatings of different $\mathrm{Al}$ contents showed a friction coefficient of about 0.6 at room temperature, independent of the $\mathrm{Al}$ content [83]. The friction value increased for $500{ }^{\circ} \mathrm{C}$ and dropped to 0.6 again at $700{ }^{\circ} \mathrm{C}$, and was also nearly independent of the $\mathrm{Al}$ content. Figure 15 shows the decreasing abrasive wear rate with increasing $\mathrm{Al}$ content for all investigated temperatures [83].

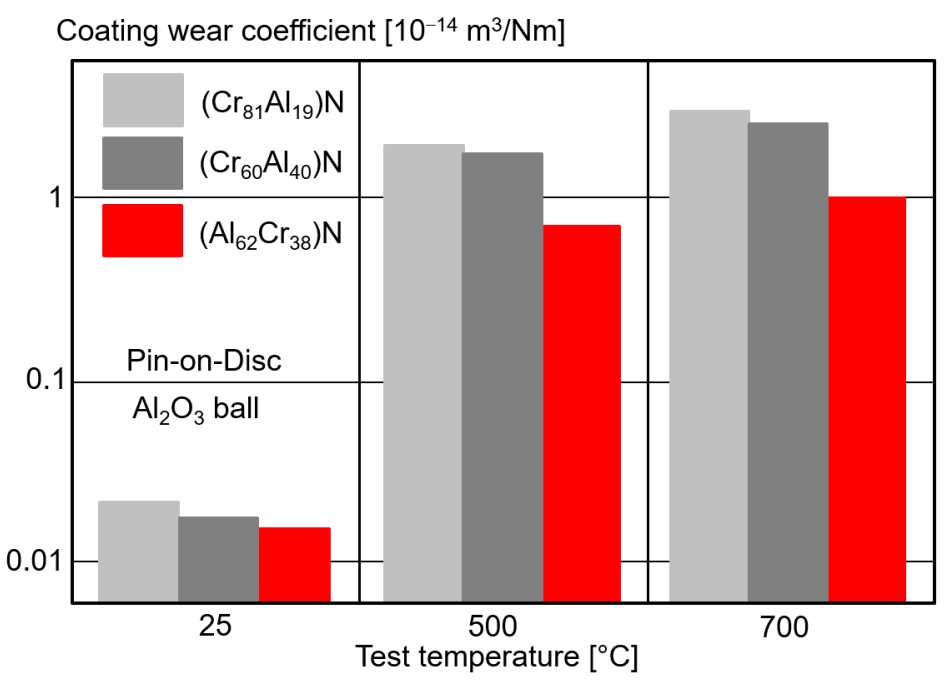

Figure 15. Wear coefficient of $(\mathrm{CrAl}) \mathrm{N}$ and $(\mathrm{AlCr}) \mathrm{N}$ coatings with different $\mathrm{Al}$ contents by pin-on-disc tests compared to $\mathrm{Al}_{2} \mathrm{O}_{3}$ balls for different test temperatures, redrawn after [83], original @ Springer Nature.

The dry tribological properties of arc-deposited $\left(\mathrm{Al}_{70} \mathrm{Cr}_{30}\right) \mathrm{N},\left(\mathrm{Al}_{67} \mathrm{Ti}_{33}\right) \mathrm{N}$, and $\mathrm{CrN}$ coatings against a $\mathrm{Si}_{3} \mathrm{~N}_{4}$ ball as the counterpart showed friction values of $0.73,0.79$, and 0.77 at the end of the test, respectively [84]. A special effect related to the wear rate was observed. The highest wear rate was measured for $\left(\mathrm{Al}_{67} \mathrm{Ti}_{33}\right) \mathrm{N}$, but $\mathrm{CrN}$ had a slightly lower wear rate than $\left(\mathrm{Al}_{70} \mathrm{Cr}_{30}\right) \mathrm{N}$. The authors claim this is caused by the tribological oxidation behaviour, which has a great influence on the wear mechanism and the debris removal behaviour of the coatings.

\subsection{Control of Coating Morphology, Stress and Texture}

$(\mathrm{CrAl}) \mathrm{N}$ and $(\mathrm{AlCr}) \mathrm{N}$ coatings synthesised using PVD processes display a rich variety of microstructures, from fine-grained morphology up to coarse columnar structures, which 
make different $(\mathrm{AlCr}) \mathrm{N}$ coatings suitable for many diverse application areas. This section focuses on $(\mathrm{AlCr}) \mathrm{N}$ coatings, though similar effects are also valid for $(\mathrm{CrAl}) \mathrm{N}$ coatings. The relationships between the deposition parameters and the coating morphology are summarised in generic structure-zone diagrams [85] to provide guidelines that can be applied for $(\mathrm{AlCr}) \mathrm{N}$ coatings in general. The deposition conditions can also be used to control the stress state of the coatings [86], which often is an important part of engineering coatings and in adapting them to different use cases and requirements. For example, thick coating layers are at risk of peeling off if the stress state is too high, while high compressive stresses can be advantageous in interrupted cutting operations. The stress state has also been pointed out as a key determining factor for thermal stability and decomposition pathways [75].

The effect of bias voltage on the stress state and coating properties of $(\mathrm{AlCr}) \mathrm{N}$ coatings deposited using $\mathrm{Al}_{60} \mathrm{Cr}_{40}$ targets has been investigated systematically [87]. Increasing the bias voltage led to higher levels of compressive residual stresses as a function of the increased ion bombardment, up to a threshold in the range of $100 \mathrm{~V}$, see Figure 16. Further higher bias values reduced the overall stress state, which was attributed to the annihilation of defects and stress relaxation. A concurrent reduction in grain size, the lattice parameter and a modified preferential orientation in XRD from (200) to a mixture of (200) and (111) were also observed as an effect of increasing the bias [87].

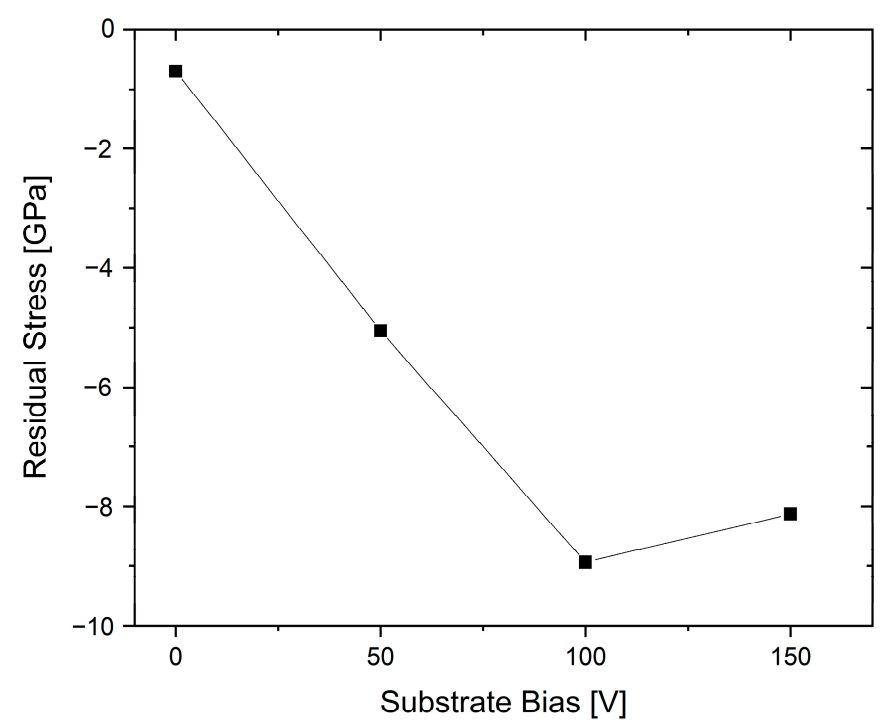

Figure 16. Compressive residual stress versus the bias voltage for arc-deposited $\left(\mathrm{Al}_{60} \mathrm{Cr}_{40}\right) \mathrm{N}$ coatings, redrawn after [87], original @ Elsevier.

Similar trends for texture and increased hardness with bias were also reported for coatings deposited using $\mathrm{Al}_{70} \mathrm{Cr}_{30}$ and $\mathrm{Al}_{75} \mathrm{Cr}_{25}$ cathodes. Coatings with a higher $\mathrm{Al}$ content, deposited using $\mathrm{Al}_{85} \mathrm{Cr}_{15}$ and $\mathrm{Al}_{90} \mathrm{Cr}_{10}$, formed dual-phase structures at bias voltages higher than $40 \mathrm{~V}$ [66]. The influence of phase structure on the stress state has been exemplified in the direct comparison of $\left(\mathrm{Al}_{80} \mathrm{Cr}_{20}\right) \mathrm{N}$ coatings, which had lower compressive stress values relative to $\left(\mathrm{Al}_{70} \mathrm{Cr}_{30}\right) \mathrm{N}$. This effect was attributed to stress relief through the presence of hexagonal phases in the former case [88].

The stress state of $(\mathrm{AlCr}) \mathrm{N}$ coatings can also be influenced by alloying elements. For example, B-alloyed coatings with 2.3-9.1 at.\% of B have been demonstrated to have lower compressive state levels compared to unalloyed coatings. The B-alloying also caused grainsize refinement and an increase in hardness attributed to a combination of solid solution hardening and Hall-Petch hardening [89]. Further aspects of alloying will be discussed later in this review.

Surface morphology, and in particular the density of macroparticles in arc deposition processes, can be influenced by the deposition pressure where fewer macroparticles are 
generated and smoother coatings are obtained at higher pressure [90-92], see also the example in Figure 17. This effect can be rationalised through a higher degree of poisoning on the target surface at an elevated pressure. Columnar morphology is typically achieved over a large process window of deposition pressures, though with variation in the column width. This is illustrated in Figure 17a-d. Further reported effects of deposition pressure include increased hardness and an influence on the phase structure [91,92].
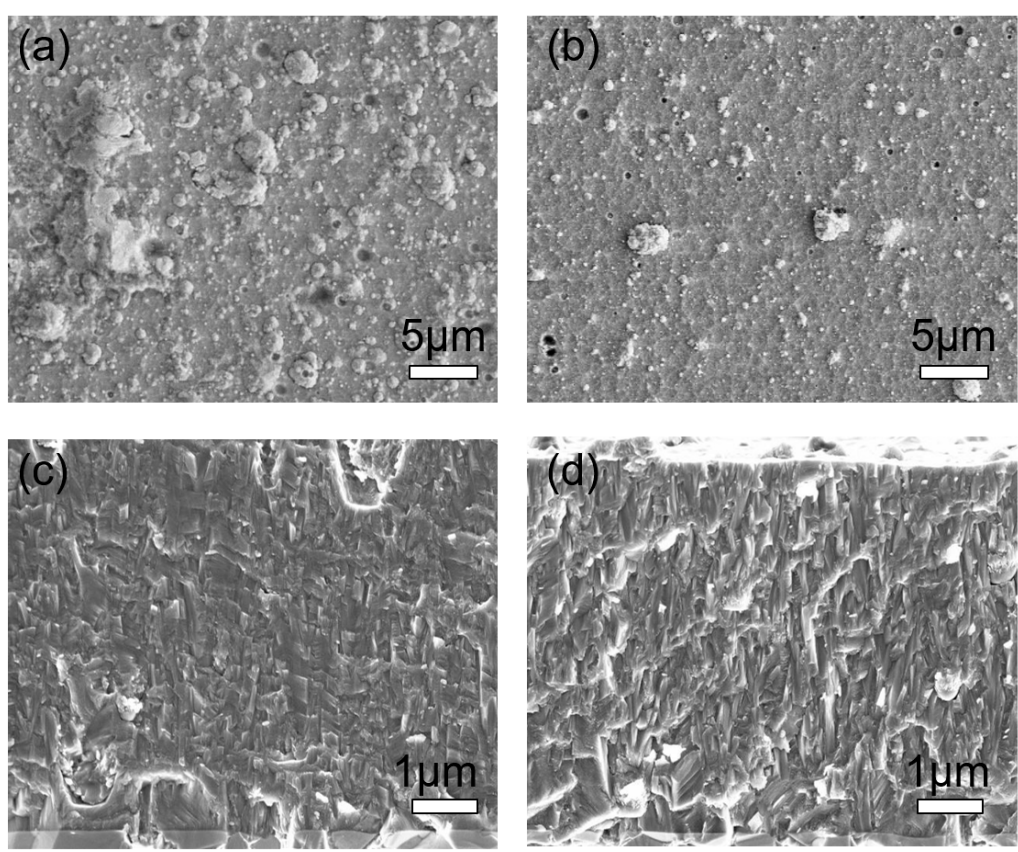

Figure 17. Surface and cross-sectional morphology of $(\mathrm{AlCr}) \mathrm{N}$ monolayer coatings deposited for $(\mathbf{a}, \mathbf{c})$ at $2.5 \mathrm{~Pa} \mathrm{~N}_{2}$ and for $(\mathbf{b}, \mathbf{d})$ at $7.5 \mathrm{~Pa} \mathrm{~N}_{2}$, for illustration of relative trends.

The structure of arc-deposited AlCr-based coatings depends not only on the cathode composition, process temperature, substrate bias potential, arc current and reactive gas pressure, but also on the arc source design, in a manner that is similar to the case of AlTi-based coatings [9]. The influence of the magnetic set-up was investigated in one coating process using two arc sources, both equipped with $\mathrm{Al}_{70} \mathrm{Cr}_{30}$ cathodes, strong and weak magnetic fields, respectively [93]. Figure 18 shows the differences between the two deposited coatings by means of XRD investigation, SEM cross-section and hardness measurement. The coating properties vary significantly. Although EPMA (Electron Probe Micro Analysis) measurements showed a lower $\mathrm{Al} /(\mathrm{Al}+\mathrm{Cr})$ content, a minor hcp face is visible in the coating deposited by the weak field, which explains the finer growth structure (smaller grains) of the coating. Furthermore, the coating deposited with the weak field contains less nitrogen and the hardness is about $30 \%$ lower compared to the coating deposited with strong magnetic fields.

\subsection{Features of ( $\mathrm{AlCr}$ )N Coatings with Mixed fcc Plus hcp Structure}

Dual-phase coatings with Al concentrations of more than 70 at.\% have been reported as monolayer coatings $[88,90,94,95]$, as well as multilayers [66,96]. The coatings are characterised by relatively low hardness compared with fcc $(\mathrm{Al}, \mathrm{Cr}) \mathrm{N}$, lower oxidation resistance than fcc $(\mathrm{Al}, \mathrm{Cr}) \mathrm{N}$ with a high $\mathrm{Al}$ content, but also with the positive effect of exhibiting lower stress. 


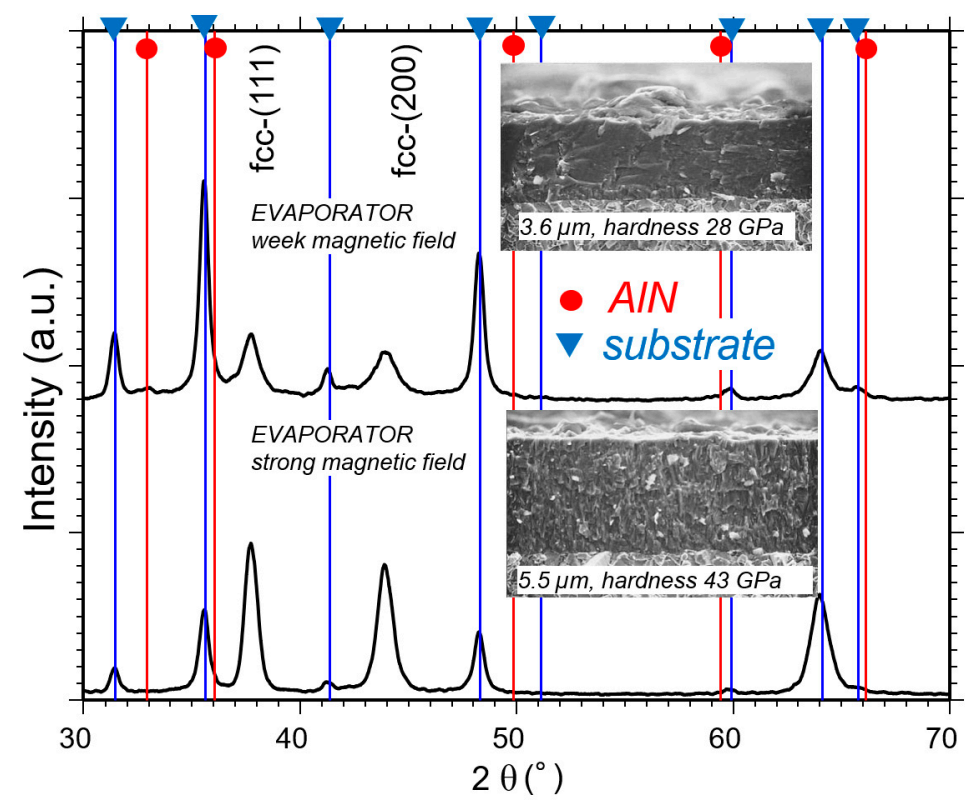

Figure 18. Phase formation of coatings deposited with pm cathodes $\mathrm{Al}_{70} \mathrm{Cr}_{30}$ for two evaporators with different magnetic field set-ups [93].

\section{Alloying of AlCrN}

The alloying (doping) of ( $\mathrm{AlCr}) \mathrm{N}$ is amongst the most important approaches used to develop and adapt these coatings. The addition of at least one alloying element (such as $\mathrm{Si}$, $\mathrm{B}, \mathrm{C}, \mathrm{O}, \mathrm{W}, \mathrm{Y}$ and others) into ( $\mathrm{AlCr}) \mathrm{N}$ coatings is used to further optimise properties and performance. Through alloying, the base coating may be improved in terms of increased hardness, higher oxidation resistance, extended thermal stability, higher wear resistance and lower friction values. The main directions in the development of alloyed $(\mathrm{AlCr}) \mathrm{N}$ coatings will be reviewed in this section. Figure 19 shows an overview of alloying concepts. Metals, metalloids, and oxygen are added as single elements or in combination with others.

Aspects of environmental sustainability have not yet been discussed in the scientific and engineering community until now. These important ecological aspects, such as selecting specific alloying elements to minimise environmental impacts in the production of the coating, the use of the coating and the recycling, were overlooked. In general, the addition of $\mathrm{O}, \mathrm{C}$ and $\mathrm{Si}$ seems to offer the most sustainable solutions. An overview of different alloying directions that have been reported is given in Table 2 .

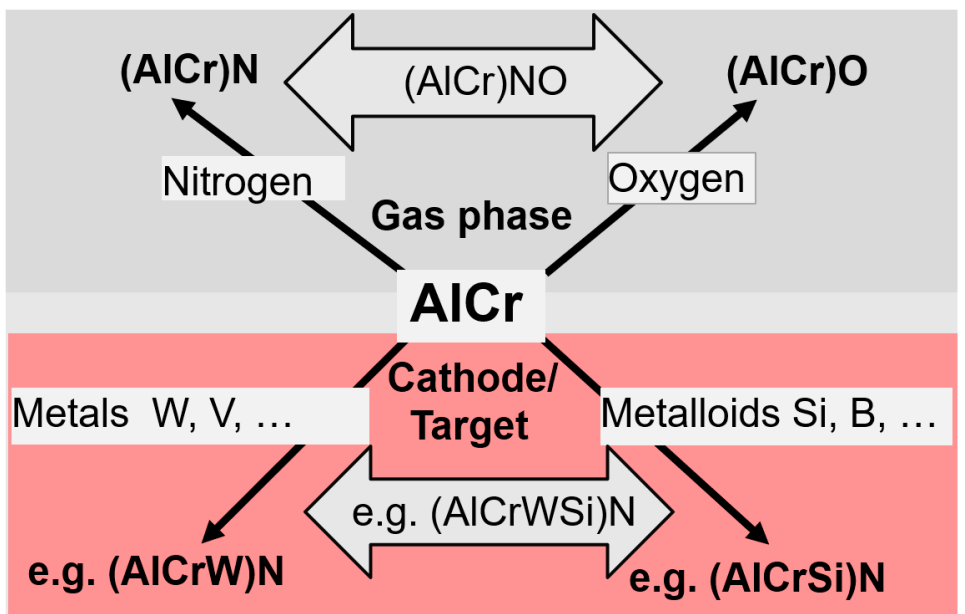

Figure 19. Directions of alloying for $(\mathrm{CrAl}) \mathrm{N}$ and $(\mathrm{AlCr}) \mathrm{N}$ designed to tune selected properties. 
Table 2. Selected coatings alloyed with one metal and metalloid component.

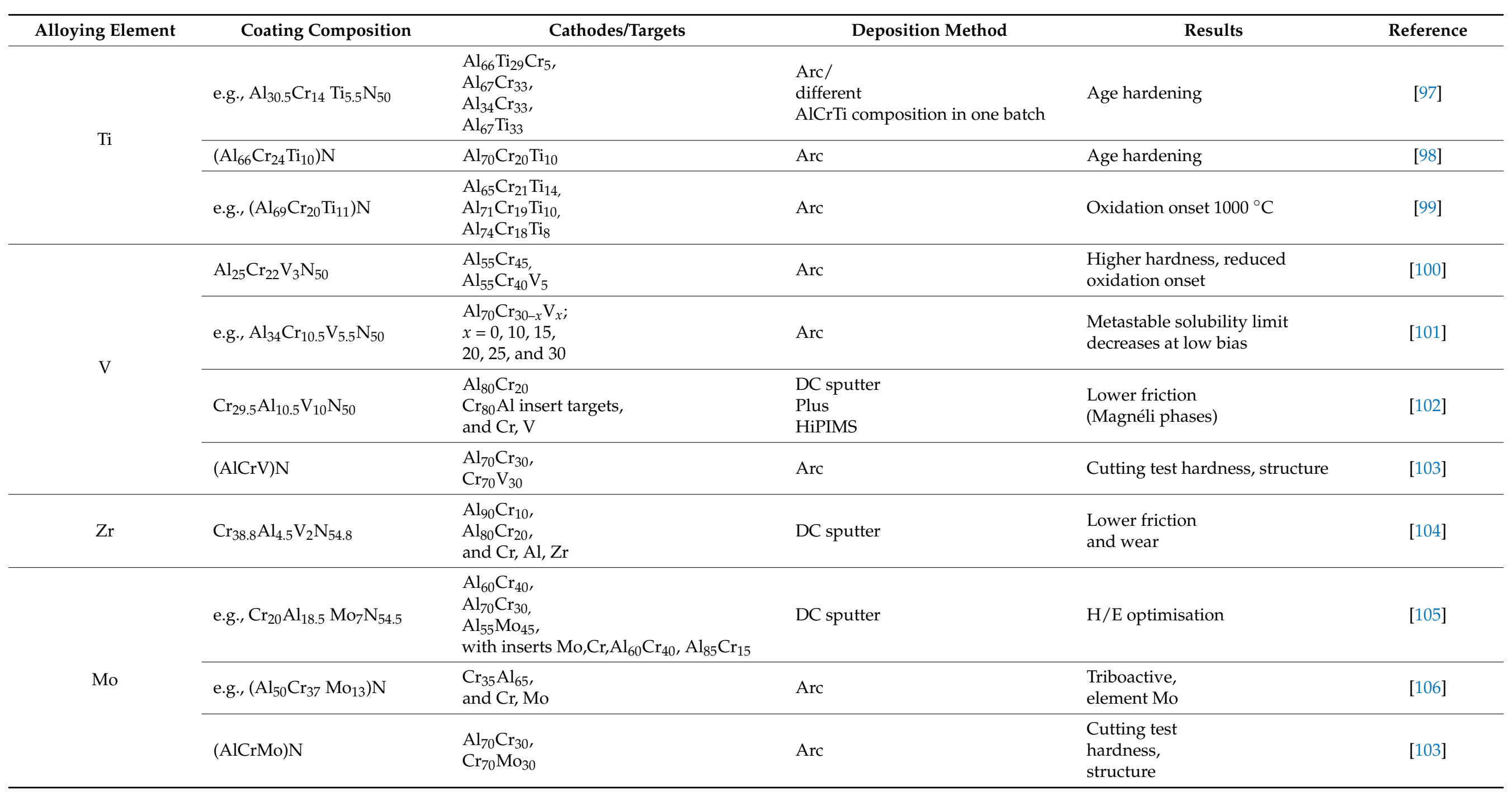


Table 2. Cont.

\begin{tabular}{|c|c|c|c|c|c|}
\hline Alloying Element & Coating Composition & Cathodes/Targets & Deposition Method & Results & Reference \\
\hline $\mathrm{Hf}$ & e.g., $\mathrm{Al}_{37} \mathrm{Cr}_{11} \mathrm{Hf}_{2} \mathrm{~N}_{50}$ & $\begin{array}{l}\mathrm{AlCr}_{20} \\
(\mathrm{Cr} \text { in } \mathrm{Al}) \text { inserted, } \\
\text { and } \mathrm{Hf}\end{array}$ & DC sputter & $\begin{array}{l}\text { Higher } \\
\text { oxidation resistance }\end{array}$ & [107] \\
\hline $\mathrm{Nb}$ & e.g., $\mathrm{Al}_{27.5} \mathrm{Cr}_{17.5} \mathrm{Nb}_{5} \mathrm{~N}_{50}$ & $\begin{array}{l}\mathrm{Al}_{55} \mathrm{Cr}_{45} \\
\mathrm{Al}_{60} \mathrm{Cr}_{35} \mathrm{Nb}_{5} \\
\mathrm{Al}_{60} \mathrm{Cr}_{30} \mathrm{Nb}_{10}\end{array}$ & Arc & $\begin{array}{l}\text { Higher hardness, } \\
\text { lower oxidation resistance }\end{array}$ & [108] \\
\hline $\mathrm{W}$ & e.g., $\left(\mathrm{Al}_{64} \mathrm{Cr}_{31} \mathrm{~W}_{5}\right) \mathrm{N}$ & $\begin{array}{l}\mathrm{Al}_{70} \mathrm{Cr}_{30} \\
\mathrm{Al}_{70} \mathrm{Cr}_{25} \mathrm{~W}_{5}\end{array}$ & Arc & $\begin{array}{l}\text { Improved oxidation resistance } \\
\text { at } 1100{ }^{\circ} \mathrm{C}\end{array}$ & [81] \\
\hline $\mathrm{Cu}$ & e.g., $\left(\mathrm{Al}_{47} \mathrm{Cr}_{34} \mathrm{Cu}_{19}\right) \mathrm{N}$ & $\begin{array}{l}\mathrm{Cr}_{35} \mathrm{Al}_{65}, \\
\text { and } \mathrm{Cr}, \mathrm{Cu}\end{array}$ & DC sputter & $\begin{array}{l}\text { Triboactive, } \\
\text { hardness } \\
\text { decrease }\end{array}$ & [106] \\
\hline \multirow[b]{2}{*}{ Y } & e.g., $\mathrm{Al}_{26.5} \mathrm{Cr}_{22.5} \mathrm{Y}_{1} \mathrm{~N}_{50}$ & $\begin{array}{l}\mathrm{Al} / \mathrm{Cr}=1.5 \\
\text { with } 0,2,4,8 \text { at. } \% \mathrm{Y}\end{array}$ & DC sputter & $\begin{array}{l}\text { Structure, } \\
\text { improved oxidation } \\
\text { resistance }\end{array}$ & {$[109,110]$} \\
\hline & e.g., $\mathrm{Al}_{23.8} \mathrm{Cr}_{23.1} \mathrm{Y}_{0.7} \mathrm{~N}_{50} \mathrm{O}_{2.4}$ & $\mathrm{Al}_{50} \mathrm{Cr}_{50}, \mathrm{Y}$ & DC sputter & Improved oxidation & [111] \\
\hline $\mathrm{La}$ & e.g., $\mathrm{Al}_{28.1} \mathrm{Cr}_{12.5} \mathrm{La}_{1.4} \mathrm{~N}_{58}$ & $\begin{array}{l}\mathrm{Al}_{70} \mathrm{Cr}_{30} \\
\text { and } \mathrm{La}\end{array}$ & DC sputter & $\begin{array}{l}\text { Wear, friction, } \\
\text { structure }\end{array}$ & [113] \\
\hline \multirow[b]{2}{*}{$\mathrm{C}$} & e.g., $\mathrm{Cr}_{44.4} \mathrm{Al}_{12} \mathrm{C}_{27.6} \mathrm{~N}_{16}$ & $\mathrm{Cr}_{2} \mathrm{AlC}$ & DC sputter & $\begin{array}{l}\text { Wear, friction, } \\
\text { structure }\end{array}$ & [114] \\
\hline & e.g., $\mathrm{Cr}_{24} \mathrm{Al}_{24} \mathrm{~N}_{48} \mathrm{C}_{4}$ & $\begin{array}{l}\mathrm{AlCr}_{20}, \\
\mathrm{AlCr}_{24}, \\
\text { Cr inserts in } \mathrm{Al}, \\
\text { and } \mathrm{Cr}\end{array}$ & $\begin{array}{l}\text { DC sputter } \\
\text { HiPIMS }\end{array}$ & $\begin{array}{l}\text { Structure, } \\
\text { hardness }\end{array}$ & [115] \\
\hline
\end{tabular}


Table 2. Cont.

\begin{tabular}{|c|c|c|c|c|c|}
\hline Alloying Element & Coating Composition & Cathodes/Targets & Deposition Method & Results & Reference \\
\hline \multirow{3}{*}{ B } & e.g., $\mathrm{Al}_{26.7} \mathrm{Cr}_{21.7} \mathrm{~B}_{2.3} \mathrm{~N}_{49.3}$ & $\begin{array}{l}\mathrm{Al}_{60} \mathrm{Cr}_{40} \\
\mathrm{Al}_{70} \mathrm{Cr}_{30} \\
\text { B alloyed } \mathrm{Al} / \mathrm{Cr}=1.8, \text { with 10, 20, } 30 \text { at.\% }\end{array}$ & Arc & $\begin{array}{l}\text { Structure, } \\
\text { phases, } \\
\text { hardness, } \\
\text { nano composite }\end{array}$ & [89] \\
\hline & e.g., $\mathrm{Al}_{30.4} \mathrm{Cr}_{16.3} \mathrm{~B}_{2.1} \mathrm{~N}_{48.1} \mathrm{O}_{3.1}$ & $\begin{array}{l}\mathrm{Al}_{55} \mathrm{Cr}_{35} \mathrm{~B}_{10} \\
\mathrm{Al}_{70} \mathrm{Cr}_{30}\end{array}$ & Arc & $\begin{array}{l}\text { Structure, } \\
\text { wear, } \\
\text { tribology }\end{array}$ & [58] \\
\hline & e.g., $\left(\mathrm{Al}_{64.5} \mathrm{Cr}_{32.9} \mathrm{~B}_{2.6}\right) \mathrm{N}$ & $\begin{array}{l}\mathrm{Al}_{70} \mathrm{Cr}_{30} \\
\mathrm{Al}_{70} \mathrm{Cr}_{25} \mathrm{~B}_{5}\end{array}$ & DC sputter & Oxidation, structure & [81] \\
\hline
\end{tabular}




\subsection{Additional Metallic Elements}

Modifications of the coating properties are possible by the addition of one or more metallic elements, e.g., Ti, V, Mo, Hf, $\mathrm{Nb}, \mathrm{W}, \mathrm{Cu}$.

\subsubsection{Coatings with the Addition of $\mathrm{Ti}, \mathrm{V}, \mathrm{Zr}$}

\section{Al-Cr-Ti-N}

Various quaternary cubic $(\mathrm{AlCrTi}) \mathrm{N}$ coatings with a composition of about $\left(\mathrm{Al}_{60}(\mathrm{Cr}, \mathrm{Ti})_{40}\right) \mathrm{N}$ and varying Ti content $(0,1,2,11$ at.\%) were deposited by cathodic arc evaporation. The hardness of the $\left(\mathrm{Al}_{30.5} \mathrm{Cr}_{14} \mathrm{Ti}_{5.5} \mathrm{~N}_{50}\right)$ coating was retained after annealing up to $1100{ }^{\circ} \mathrm{C}$. The coating also showed an age hardening process caused by spinodal decomposition similar to (AlTi)N [97]. However, the oxidation resistance was found to be slightly reduced compared to unalloyed ( $\mathrm{AlCr}) \mathrm{N}$ coatings. The age hardening effect was also discussed for AlCrTiN coatings with a higher $\mathrm{Al}$ content $\left(\mathrm{Al}_{66} \mathrm{Cr}_{24} \mathrm{Ti}_{10}\right) \mathrm{N}$ [98]. It was shown that the oxidation resistance of $\left(\mathrm{Al}_{69} \mathrm{Cr}_{20} \mathrm{Ti}_{11}\right) \mathrm{N}$ was significantly increased as compared to $\left(\mathrm{Ti}_{50} \mathrm{Al}_{50}\right) \mathrm{N}[99]$.

\section{Al-Cr-V-N}

$\mathrm{Al}_{26} \mathrm{Cr}_{24} \mathrm{~N}_{50}$ and $\mathrm{Al}_{25} \mathrm{Cr}_{22} \mathrm{~V}_{3} \mathrm{~N}_{50}$ coatings were deposited by arc evaporation. It was shown that $\mathrm{V}$ doping increased the hardness from ca. 31 to $33 \mathrm{GPa}$, but the oxidation resistance was decreased [100]. Systematic investigations of arc-deposited coatings using $\left(\mathrm{Al}_{70} \mathrm{Cr}_{30}\right)_{1-x} \mathrm{~V}_{x}$ cathodes with compositions of $x=0,10,5,20,25$, and 30 at.\% showed that the incorporation of $\mathrm{V}$ into $\mathrm{AlCrN}$ coatings triggers a phase separation into fcc-CrN and hcp-AlN structured grains, even at a low content [101]. Higher bias voltages stabilise the fcc structure.

$\mathrm{Cr}_{29.5} \mathrm{Al}_{10.5} \mathrm{~V}_{10} \mathrm{~N}_{50}$ sputtered coatings showed a decrease in the friction coefficient at higher temperatures $\left(600\right.$ and $800^{\circ} \mathrm{C}$ ) due to phase transformation towards the Magnéli phase $\mathrm{V}_{3} \mathrm{O}_{7}$ in pin-on-disc tribometer testing [102].

$(\mathrm{AlCrV}) \mathrm{N}$ coatings were deposited by arc using $\mathrm{Al}_{70} \mathrm{Cr}_{30}$ and $\mathrm{Cr}_{70} \mathrm{~V}_{30}$ cathodes [103]. The $(\mathrm{AlCrV}) \mathrm{N}$ coating had a higher hardness and a lower friction value and wear rate than the $\left(\mathrm{Al}_{70} \mathrm{Cr}_{30}\right) \mathrm{N}$ coating. The coating containing $\mathrm{V}$ showed a higher service life in a milling cutting test. A reason might be the formation of lubricious $\mathrm{VO}_{x}$ phases.

\section{Cr-Al-Zr-N}

A sputtered Cr-rich (CrAlZr) N coating with the composition of $\mathrm{Cr}_{38.8} \mathrm{Al}_{4.5} \mathrm{~V}_{2} \mathrm{~N}_{54.8}$ was shown to form a $\mathrm{Cr}_{2} \mathrm{O}_{3}$-rich tribolayer that decreases friction and wear [104].

\subsubsection{Coatings with the Addition of Refractory Metals}

\section{Al-Cr-Mo-N}

Basic investigations of sputtered coatings showed that the addition of Mo significantly increases the hardness in a comparison, for example, of $\mathrm{Cr}_{20} \mathrm{Al}_{18.5} \mathrm{Mo}_{7} \mathrm{~N}_{54.5}$ at $37 \mathrm{GPa}$ to unalloyed $\mathrm{Al}_{23} \mathrm{Cr}_{20} \mathrm{~N}_{57}$ at $29 \mathrm{GPa}$ [105]. Other (AlCrMo)N coatings (e.g., $\left(\mathrm{Al}_{50} \mathrm{Cr}_{37} \mathrm{Mo}_{13}\right) \mathrm{N}$ ) were deposited by means of cathodic arc evaporation. The addition of Mo was shown to have a high potential to act as a triboactive coating when lubricated with lubricants containing sulphur [106]. ( $\mathrm{AlCrMo}) \mathrm{N}$ coatings have also been deposited by arc using $\mathrm{Al}_{70} \mathrm{Cr}_{30}$ and $\mathrm{Cr}_{70} \mathrm{Mo}_{30}$ cathodes [103]. The (AlCrMo) N coating had slightly higher hardness and a lower friction value and wear rate than the $\left(\mathrm{Al}_{70} \mathrm{Cr}_{30}\right) \mathrm{N}$ coating. The coating containing Mo showed a higher service life in a milling cutting test. A reason might be the formation of lubricious $\mathrm{MoO}_{x}$ phases.

\section{Al-Cr-Hf-N}

$\mathrm{AlCrN}(\mathrm{Al} / \mathrm{Cr}=3.2)$ and $\mathrm{AlCrHfN}$ coatings with an $\mathrm{Al} / \mathrm{Cr}$ ratio $>3$ and varying $\mathrm{Hf}$ content between 0 and 11.6 at.\% have been synthetised by DC magnetron sputtering. The hardness was found to decrease slightly with an increasing Hf content, from $22 \mathrm{GPa}$ to $19 \mathrm{GPa}$. The oxidation resistance of $\mathrm{AlCrN}$ increased by alloying it with a small amount 
of $\mathrm{Hf}$ of about 2 at.\% (e.g., $\mathrm{Al}_{37} \mathrm{Cr}_{11} \mathrm{Hf}_{2} \mathrm{~N}_{50}$ ); however, it decreases again at the highest $\mathrm{Hf}$ content [107].

\section{Al-Cr-Nb-N}

Fcc-structured $\mathrm{Al}_{26} \mathrm{Cr}_{24} \mathrm{~N}_{50}, \mathrm{Al}_{23.5} \mathrm{Cr}_{19} \mathrm{Nb}_{2.5} \mathrm{~N}_{50}$ and $\mathrm{Al}_{27.5} \mathrm{Cr}_{17.5} \mathrm{Nb}_{5} \mathrm{~N}_{50}$ coatings were deposited by cathodic arc evaporation. The hardness increased slightly with the addition of $\mathrm{Nb}$ from 31 to $32 \mathrm{GPa}$ at room temperature, but the increase in hardness is more pronounced after annealing at a temperature of around $1000{ }^{\circ} \mathrm{C}$ (plus $3 \mathrm{GPa}$ ). The phase stability was shifted to include higher temperatures with the addition of $\mathrm{Nb}$, but the oxidation resistance decreases [108].

\section{Al-Cr-W-N}

$(\mathrm{AlCr}) \mathrm{N}$ and $(\mathrm{AlCrW}) \mathrm{N}$ coatings have been deposited by the cathodic vacuum arc method using cathodes of $\mathrm{Al}_{70} \mathrm{Cr}_{25} \mathrm{~W}_{5}$ and $\mathrm{Al}_{70} \mathrm{Cr}_{30}$. The coating had a $\mathrm{W}$ content that was about the same as in the cathode and an $\mathrm{Al} / \mathrm{Cr}$ ratio of $2,\left(\mathrm{Al}_{64} \mathrm{Cr}_{31} \mathrm{~W}_{5}\right) \mathrm{N}$. Oxidation tests showed that the $(\mathrm{AlCrW}) \mathrm{N}$ coating had higher oxidation stability than the $(\mathrm{AlCr}) \mathrm{N}$ coating at $1100{ }^{\circ} \mathrm{C}$; however, it was worse than $(\mathrm{AlCr}) \mathrm{N}$ at $900{ }^{\circ} \mathrm{C}$ [81].

\subsubsection{Coatings with the Addition of Non-Ferrous Metals}

\section{Al-Cr-Cu-N}

$\left(\mathrm{Al}_{53} \mathrm{Cr}_{47}\right) \mathrm{N}$ and $\left(\mathrm{Al}_{47} \mathrm{Cr}_{34} \mathrm{Cu}_{19}\right) \mathrm{N}$ were deposited by means of cathodic arc evaporation. It was shown that the $\mathrm{Cu}$ is present mainly in metallic form. The alloying with $\mathrm{Cu}$ was found to decrease the hardness from 30 to $25 \mathrm{GPa}$ [106].

\subsection{Coatings with the Addition of Rare Earth Elements}

The effect of $\mathrm{Y}$ and La has been studied in $\mathrm{AlCrN}$-based coatings.

\section{Al-Cr-Y-N}

The oxidation behaviour of $\mathrm{Al}_{27} \mathrm{Cr}_{46} \mathrm{~N}_{50}$ and Y-doped coatings was investigated. $\mathrm{Al}_{26.5} \mathrm{Cr}_{22.5} \mathrm{Y}_{1} \mathrm{~N}_{50}$ and $\mathrm{Al}_{26.5} \mathrm{Cr}_{21.5} \mathrm{Y}_{2} \mathrm{~N}_{50}$ coatings showed improved oxidation resistance, whereas a further increase ( 4 at. $\%$ in the coating) in $Y$ had a negative influence. Experimental and computational studies on the effect of yttrium on the phase formation of sputtered $(\mathrm{AlCrY}) \mathrm{N}$ showed a decrease in the maximum $\mathrm{Al}$ content with retained fcc structure to 68 at. $\%$ at a $Y$ content of 2 at.\% of the total metal content. The authors concluded that, theoretically, the $\mathrm{Al}_{34} \mathrm{Cr}_{15} \mathrm{Y}_{1} \mathrm{~N}_{50}$ coatings exhibit the most promising oxidation resistance within the group of coatings containing $\mathrm{Y}$ as compared to $(\mathrm{AlCr}) \mathrm{N}$ coatings [109,110]. (CrAlY)N coatings with a $\mathrm{Y}$ content up to 2.3 at.\% were co-sputtered using $\mathrm{Cr}_{50} \mathrm{Al}_{50}$-composite and pure $\mathrm{Y}$ targets. The hardness increased from ca. 16 to $24 \mathrm{GPa}$ with increasing $\mathrm{Y}$ content. However, oxidation experiments $\left(1100^{\circ} \mathrm{C}\right)$ demonstrated a lower $\mathrm{Y}$ content of 0.3 to 0.7 at.\% (e.g., $\mathrm{Al}_{23.8} \mathrm{Cr}_{23.1} \mathrm{Y}_{0.7} \mathrm{~N}_{50} \mathrm{O}_{2.4}$ ) to be beneficial for the oxidation resistance. In excess of 1.3 at. $\% \mathrm{Y}$, the oxidation resistance deteriorated as the result of the formation of porous and non-protective oxide scales [111]. A further study of co-sputtered coatings containing $\mathrm{Y}$ showed that excellent oxidation behaviour was achieved with a $\mathrm{Y}$ content of 3.4 at.\% for Cr-rich $\mathrm{Cr}_{25.8} \mathrm{Al}_{15.3} \mathrm{Y}_{3.4} \mathrm{~N}_{55.5}$ coatings, whereas for Al-rich coatings, a lower $\mathrm{Y}$ content of 2.6 at.\% was the best with $\mathrm{Al}_{24.9} \mathrm{Cr}_{18.1} \mathrm{Y}_{2.6} \mathrm{~N}_{54.4}$. It was also found that higher $\mathrm{Y}$ contents promote the hcp phase formation [112].

It can thus be concluded that a low Y content in the range of about 0.7 to 3.4 at. $\%$ of the total elemental composition of the coating can have a positive effect on the oxidation. However, the absolute value seems to be dependent on the $\mathrm{Al} / \mathrm{Cr}$ ratio in the coating.

\section{Al-Cr-La-N}

$\mathrm{Al}_{29.1} \mathrm{Cr}_{13.5} \mathrm{~N}_{57.4}$ and (AlCrLa) $\mathrm{N}$ coatings were deposited by sputtering using $\mathrm{Al}_{70} \mathrm{Cr}_{30}$ and La targets. The concentration of La was varied in the range of 1.39 to 7.73 at.\% by adjusting the sputtering power for the $\mathrm{La}$ target. A small amount of La, e.g., $\mathrm{Al}_{28.1} \mathrm{Cr}_{12.5} \mathrm{La}_{1.4} \mathrm{~N}_{58}$, formed a solid solution in the ( $\mathrm{AlCr}) \mathrm{N}$ lattice, resulting in grain refinement. The hardness of (AlCrLa) N containing 1.4 at.\% La was significantly higher than that of the undoped 
$(\mathrm{AlCr}) \mathrm{N}$. This coating showed the lowest wear rate. An increased amount of La resulted in a grain boundary segregation, thus an nc-(AlCrLa) N coating consisting of an (AlCrLa)N matrix combined with a- $\mathrm{La}_{2} \mathrm{O}_{3} / \mathrm{a}-\mathrm{LaN}$ segregations. The hardness decreased with an increase in $\mathrm{La}$ content at the same time as the friction value (against $\mathrm{Si}_{3} \mathrm{~N}_{4}$ ) was reduced [113].

\subsection{Coatings with the Addition of Carbon}

\section{Al-Cr-N-C}

$\mathrm{Cr}_{44.4} \mathrm{Al}_{12} \mathrm{C}_{27.6} \mathrm{~N}_{16}$ coatings have been deposited by reactive magnetron sputtering using a $\mathrm{Cr}_{2} \mathrm{AlC}$ target. The coatings showed a phase mixture of $\mathrm{c}-\mathrm{CrC}, \mathrm{h}-\mathrm{AlN}$ and $\mathrm{Cr}$ with $23 \mathrm{GPa}$ hardness. In addition, the structure started to change at $800{ }^{\circ} \mathrm{C}\left(\mathrm{h}-\mathrm{Cr}_{2} \mathrm{AlC}\right.$, $\left.\mathrm{Cr}_{3} \mathrm{C}_{2}, \mathrm{Cr}_{7} \mathrm{C}_{3}, \mathrm{AlN}\right)$ [114]. Better coating properties than those of the $(\mathrm{CrAlC}) \mathrm{N}$ coating were described for the more complex (CrAlTi) $\mathrm{CN}$ coating.

DC/HiPIMS sputtered $\mathrm{Cr}_{25} \mathrm{Al}_{24} \mathrm{~N}_{51}$ and (CrAl)NC coatings with a $\mathrm{Cr} / \mathrm{Al}$ of ca. 1 and $\mathrm{N}>\mathrm{C}$ were investigated with a carbon content in the range of 1-18 at.\% [115]. Nanocomposite structured $(\mathrm{CrAl}) \mathrm{NC} / \mathrm{a}-\mathrm{C}$ coatings are formed when a critical carbon content is exceeded (a few at.\%). Crystalline ( $\mathrm{CrAl}) \mathrm{NC}$ phases are surrounded by an amorphous carbon phase. This effect was also detected for carbon-doped AlTi-based coatings, both for sputtering [116] and arc deposition [13].

It was shown that first the hardness significantly increases from 22 to $30 \mathrm{GPa}$ for a carbon content of up to about 4 at.\%, e.g., $\mathrm{Cr}_{24} \mathrm{Al}_{24} \mathrm{~N}_{48} \mathrm{C}_{4}$, then the hardness drops to about $15 \mathrm{GPa}$ at a carbon content of 18 at.\%. The hardness drop is enforced by two effects; by the continually growing amorphous phase-containing amorphous carbon and amorphous $\mathrm{CrC}_{x}$-and by the formation of hcp AlN. The carbon-doped (CrAl)NC coatings showed improved frictional characteristics in metal forming.

\subsection{Coatings with the Addition of Metalloids}

4.4.1. Coatings with the Addition of B

\section{Al-Cr-B-N}

$(\mathrm{AlCr}) \mathrm{N}$ and $(\mathrm{AlCrB}) \mathrm{N}$ coatings were arc deposited using $\mathrm{Al}_{70} \mathrm{Cr}_{30}, \mathrm{Al}_{60} \mathrm{Cr}_{40}$ and $\mathrm{B}$-doped cathodes with a constant $\mathrm{Al} / \mathrm{Cr}$ atomic ratio of 1.8 and varying $\mathrm{B}$ content of 10,20 and 30 at.\% [89]. The resulting coatings had a $\mathrm{B}$ content between $2.3, \mathrm{Al}_{26.7} \mathrm{Cr}_{21.7} \mathrm{~B}_{2.3} \mathrm{~N}_{49.3}$, and 9.1 at. $\%, \mathrm{Al}_{22.7} \mathrm{Cr}_{20.5} \mathrm{~B}_{9.1} \mathrm{~N}_{47.7}$, corresponding to $(\mathrm{Al}+\mathrm{Cr}) / \mathrm{B}$ ratios in the range 0.040.21 . The authors stated that even at low $\mathrm{B}$ contents, $\mathrm{B}$ segregates to the grain boundaries where $(\mathrm{AlCrB}) \mathrm{N}$ crystallites are at least partially covered by an a- $\mathrm{BN}_{x}$ tissue phase. A nanocomposite structure was formed at compositions of $\geq 5.7$ at. $\% \mathrm{~B}$, consisting of fcc$(\mathrm{Al}, \mathrm{Cr}, \mathrm{B}) \mathrm{N}$ grains surrounded by an amorphous $\mathrm{BN}_{\mathrm{x}}$ phase dependent on the $\mathrm{B}$ content. The hardness was significantly increased from ca. $30 \mathrm{GPa}$ for coatings containing no $\mathrm{B}$ to a maximum of about $40 \mathrm{GPa}$ for a B content of 5.7 at.\%. The addition of B acts as a grain refiner where the highest $B$ content of 9.1 at.\% reduced the grain size down to $5 \mathrm{~nm}$. It was also shown that the addition of $B$ decreases the coating stress.

A similar investigation of arc deposited coatings was carried out using cathodes of $\mathrm{Al}_{70} \mathrm{Cr}_{30}$ and $\mathrm{Al}_{55} \mathrm{Cr}_{35} \mathrm{~B}_{10}$ [58]. The $(\mathrm{AlCrB}) \mathrm{N}$ coating contained 2.1 at.\% of $\mathrm{B}$ for $\mathrm{Al}_{30.4} \mathrm{Cr}_{16.3} \mathrm{~B}_{2.1} \mathrm{~N}_{48.1} \mathrm{O}_{3.1}$, with $(\mathrm{Al}+\mathrm{Cr}) / \mathrm{B}=0.045$ and $\mathrm{Al} / \mathrm{Cr}=1.86$, and was reported to be composed of an fcc solid solution when measured by XRD. XPS measurements showed peaks of B-N and Cr-B bondings. Thus, a $\mathrm{BN}_{\mathrm{x}}$ tissue phase formation is highly probable. The $\mathrm{B}$ alloying significantly increased the hardness from the $\mathrm{B}$-free $\mathrm{Al}_{33.1} \mathrm{Cr}_{15.8} \mathrm{~N}_{48.1} \mathrm{O}_{3}$ at 31 to $37 \mathrm{GPa}$. The grain size concurrently decreases from 16 to $5 \mathrm{~nm}$. The friction value and the wear rate measured by pin-on-disc were lower than that of the coating with no $B$.

( $\mathrm{AlCrB}) \mathrm{N}$ coatings have been deposited by the cathodic vacuum arc method using cathodes of $\mathrm{Al}_{70} \mathrm{Cr}_{25} \mathrm{~B}_{5}$ and $\mathrm{Al}_{70} \mathrm{Cr}_{30}$. The $(\mathrm{AlCrB}) \mathrm{N}$ coating had an $\mathrm{Al} / \mathrm{Cr}$ ratio of 1.96 and a $\mathrm{B} /(\mathrm{Al}+\mathrm{Cr}) /$ ratio of 0.04 . Oxidation tests at $900{ }^{\circ} \mathrm{C}$ showed that this particular $\left(\mathrm{Al}_{64.5} \mathrm{Cr}_{32.9} \mathrm{~B}_{2.6}\right) \mathrm{N}$ coating had a lower oxidation stability than the $\mathrm{AlCrN}$ coating [81].

In general, it can be concluded that the addition of $\mathrm{B}$ decreases the grain size in combination with an increase in hardness of around $30 \%$. 


\subsubsection{Coatings with the Addition of $\mathrm{Si}$}

$\mathrm{Si}$ addition is the most investigated alloying element, with the goal of achieving an improvement of mechanical properties and oxidation resistance [72,117-121]. The properties are mainly dependent on the $\mathrm{Si}$ content at a given $\mathrm{Al} / \mathrm{Cr}$ ratio, and also on the deposition technology. The $\mathrm{Al} / \mathrm{Cr}$ ratio and the addition of $\mathrm{Si}$ have to be optimised to keep the results primarily in the structural zone of fcc-CrAlSiN or fcc-AlCrSiN so that suitable mechanical properties can be achieved, particularly for applications on cutting tools.

Figure 20 shows a schematic representation of the structural evolution as a function of the $\mathrm{Al} / \mathrm{Cr}$ ratio and Si content. In a first approximation, the limit of the $\mathrm{Al}$ content to obtain a coating dominated by the fcc phase is assumed to be about the same as for Si-free coatings (ca. 70 at.\% $\mathrm{Al}$ ).

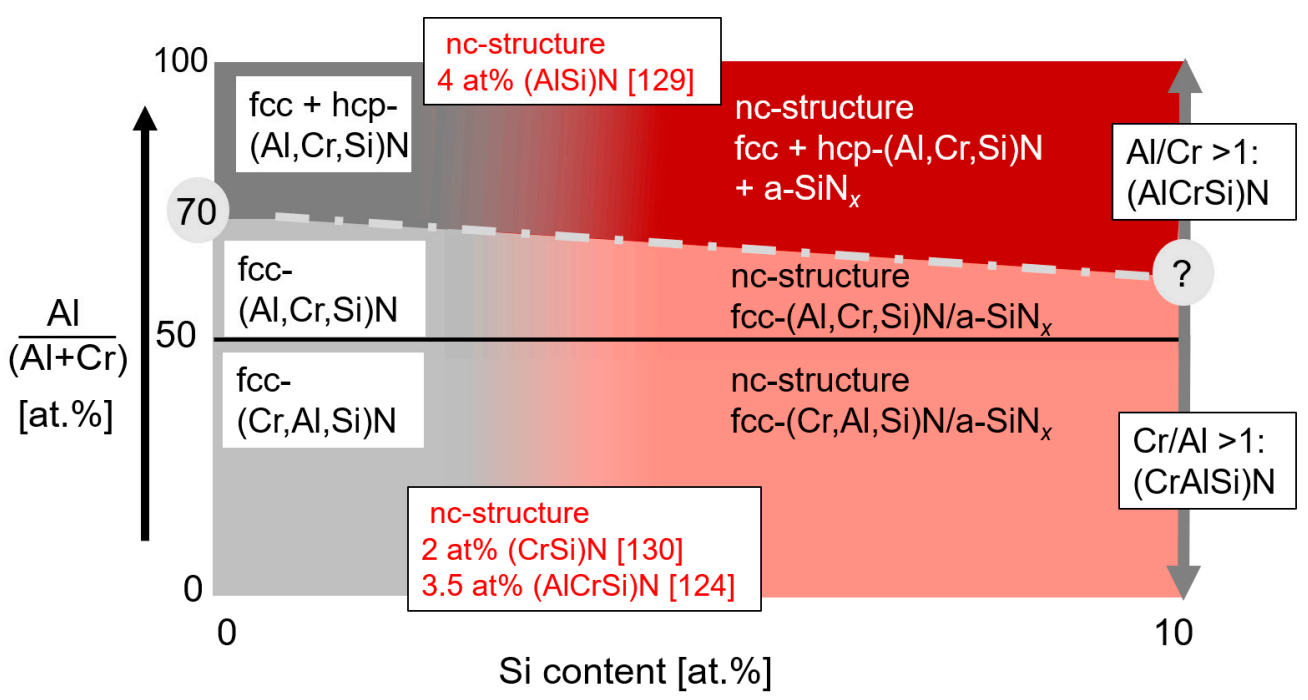

Figure 20. Schematic diagram of the phase evolution for (CrAlSi)N and ( $\mathrm{AlCrSi}) \mathrm{N}$ for different $\mathrm{Al}$ and $\mathrm{Si}$ contents in the coating, $\mathrm{nc}=$ nanocomposite.

However, it was shown that the addition of Si promotes the formation of the hcp phase. Arc-deposited coatings use a constant $\mathrm{Al}$ content of 70 at.\% in the cathode, but with a different $\mathrm{Cr}$ and $\mathrm{Si}$ content $(0,1,2,5$ at.\% Si) [72]. For coatings synthesised at low bias voltages $(40 \mathrm{~V})$, a phase separation into fcc $(\mathrm{Al}, \mathrm{Cr}, \mathrm{Si}) \mathrm{N}$ and hcp $(\mathrm{Al}, \mathrm{Cr}, \mathrm{Si}) \mathrm{N}$ for Si contents of around 1 at. $\%$ in the coating, e.g., $\mathrm{Al}_{33} \mathrm{Cr}_{16} \mathrm{Si}_{1} \mathrm{~N}_{51}$, was observed. This results in a congruent drop in mechanical properties. The hardness decreased from $30 \pm 2 \mathrm{GPa}$ for $\mathrm{Al}_{32} \mathrm{Cr}_{17} \mathrm{~N}_{51}$ coatings to $21 \mathrm{GPa}$ for the coating $\mathrm{Al}_{32} \mathrm{Cr}_{14.5} \mathrm{Si}_{2.5} \mathrm{~N}_{51}$ deposited using $\mathrm{Al}_{70} \mathrm{Cr}_{25} \mathrm{Si}$ targets. Higher bias voltage favoured the fcc phase formation. However, it is unclear if this is due to growth effects or due to a decrease in the $\mathrm{Al}$ and $\mathrm{Si}$ contents as a secondary effect of the bias voltage [72].

$\mathrm{AlCrSi}$ cathodes with a constant $\mathrm{Cr}$ content of 30 at.\%, but with varying $\mathrm{Al}$ and $\mathrm{Si}$ silicon concentrations $(0,1,2,5,10$ at. $\% \mathrm{Si})$, were deposited by cathodic arc evaporation [73]. $\mathrm{The} \mathrm{Al} /(\mathrm{Al}+\mathrm{Cr})$ ratio of the coatings decreased from about 0.68 to about 0.64 at the highest $\mathrm{Si}$ content. Up to a Si-content of about 1 at.\% (corresponding to cathodes with 2 at. $\% \mathrm{Si}$ ), the coatings showed an fcc structure, $\mathrm{Al}_{33.9} \mathrm{Cr}_{18.1} \mathrm{Si}_{1.1} \mathrm{~N}_{51} \mathrm{O}_{0.9}$. The coating with a composition of about $\mathrm{Al}_{33.4} \mathrm{Cr}_{18.3} \mathrm{Si}_{2.3} \mathrm{~N}_{46} \mathrm{O}_{0.7}$ (5 at.\% in the cathodes) displayed the formation of the hcp phase at an $\mathrm{Al} /(\mathrm{Al}+\mathrm{Cr})$ ratio of only about 0.65 and a Si content of about 2 at.\%.

Investigations of whether the addition of $\mathrm{Si}$ decreases the phase stability of the fcc phase at higher temperatures are lacking. In addition, it is also not clear how much $\mathrm{Si}$ can be substitutionally incorporated into $(\mathrm{CrAl}) \mathrm{N}$ and $(\mathrm{AlCr}) \mathrm{N}$ at a given $\mathrm{Al}$ content, and what the critical $\mathrm{Si}$ content is for the segregation of an amorphous $\mathrm{SiN}_{\mathrm{x}}$ phase at the grain boundaries. 
Above the solid solubility limit of $\mathrm{Si}$, a nanocomposite (nc) structure is formed [35,121-127]. The Si segregates along the grain boundaries, thus an amorphous $\mathrm{SiN}_{\mathrm{x}}$ phase grows. This effect has been observed for both $(\mathrm{CrSi}) \mathrm{N}$ and $(\mathrm{AlSi}) \mathrm{N}$. A schematic structural model for $(\mathrm{CrSi}) \mathrm{N}$ was shown in [128]. It was determined that for $(\mathrm{AlSi}) \mathrm{N}$, the tissue phase is generated for (AlSi) $\mathrm{N}$ in a coating containing 4 at. $\%$ of $\mathrm{Si}, \mathrm{Al}_{46} \mathrm{Si}_{4} \mathrm{~N}_{50}$. The authors showed that the nanocomposite was formed at 6 at.\% $\mathrm{Si}$ in the coating for $\mathrm{Al}_{44} \mathrm{Si}_{6} \mathrm{~N}_{50}$ [129].

A nanocomposite structure was also detectable for $(\mathrm{CrSi}) \mathrm{N}$ with a Si content of about 2 at.\% or more [130]. Analogous phase evolution was shown for coatings with a low aluminium content $(\mathrm{Cr} / \mathrm{Al}$ ca. 3$)$ for $(\mathrm{CrAlSi}) \mathrm{N}$ [35]. An $(\mathrm{AlCrSi}) \mathrm{N}$ coating with a nanocomposite structure was demonstrated at a Si content of 3.5 at.\% [124].

Unfortunately, no systematic investigations of the minimum Si content for different $\mathrm{Al}$ contents in a (CrAlSi)N or $(\mathrm{AlCrSi}) \mathrm{N}$ coating are available. Roughly, it can be deduced that a nanocomposite structure might be generated at a Si content of between 2 and 4 at.\% of the total chemical composition $(\mathrm{Al}+\mathrm{Cr}+\mathrm{Si}+\mathrm{N}$ content in at.\% equal to $100 \mathrm{at} . \%)$. It was shown that the addition of Si not only has an influence on the thermal properties of $(\mathrm{AlCr}) \mathrm{N}$, but also acts as a grain-size refiner. Depending on the amount of Si, the grain size is in the range of less than $10 \mathrm{~nm}[124,131]$.

A comparison of the oxidation behaviour of $(\mathrm{AlCr}) \mathrm{N}(\mathrm{Al} / \mathrm{Cr}=1.25),(\mathrm{CrAlSi}) \mathrm{N}$ $(\mathrm{Cr} / \mathrm{Al}=1.16)$ and $(\mathrm{AlCrSi}) \mathrm{N}(\mathrm{Al} / \mathrm{Cr}=1.89)$ coatings revealed that the coating $(\mathrm{AlCrSi}) \mathrm{N}$ with 3.3 at.\% Si, $\mathrm{Al}_{32.7} \mathrm{Cr}_{17.4} \mathrm{Si}_{3.3} \mathrm{~N}_{44.3} \mathrm{O}_{2.3}$, showed the highest oxidation resistance [80]. Additional work was performed to investigate the oxidation of various Si-free and Sicontaining coatings [119]. Figure 21 shows the specific weight gain of fcc-structured $(\mathrm{CrAl}) \mathrm{N},(\mathrm{CrAlSi}) \mathrm{N}$ and $(\mathrm{AlCr}) \mathrm{N},(\mathrm{AlCrSi}) \mathrm{N}$ coatings measured using TGA in synthetic air. The authors showed that the formation of a crystalline corundum type mixed and/or layered $\left(\mathrm{Al}_{x} \mathrm{Cr}_{1-x}\right)_{2} \mathrm{O}_{3}$ oxide scale, composed of $\mathrm{Cr}$-rich and Al-rich areas, is typical for $(\mathrm{CrAl}) \mathrm{N},(\mathrm{AlCr}) \mathrm{N}$ and $(\mathrm{CrAlSi}) \mathrm{N}$ and $(\mathrm{AlCrSi}) \mathrm{N}$ coatings for coatings with low Si contents. The oxide layer formed prevents further oxidation. A special case was observed for high $\mathrm{Si}$ contents, e.g., a $\left(\mathrm{Cr}_{45} \mathrm{Al}_{39} \mathrm{Si}_{16}\right) \mathrm{N}$ coating, where the highest onset temperature for oxidation was observed accompanied with the lowest weight gain. The reason is that a crystalline $\mathrm{SiO}_{2}$ phase grows in addition to $\left(\mathrm{Al}_{x} \mathrm{Cr}_{1-x}\right)_{2} \mathrm{O}_{3}$. This effect might be used for some coating solutions requiring a low oxidation rate.

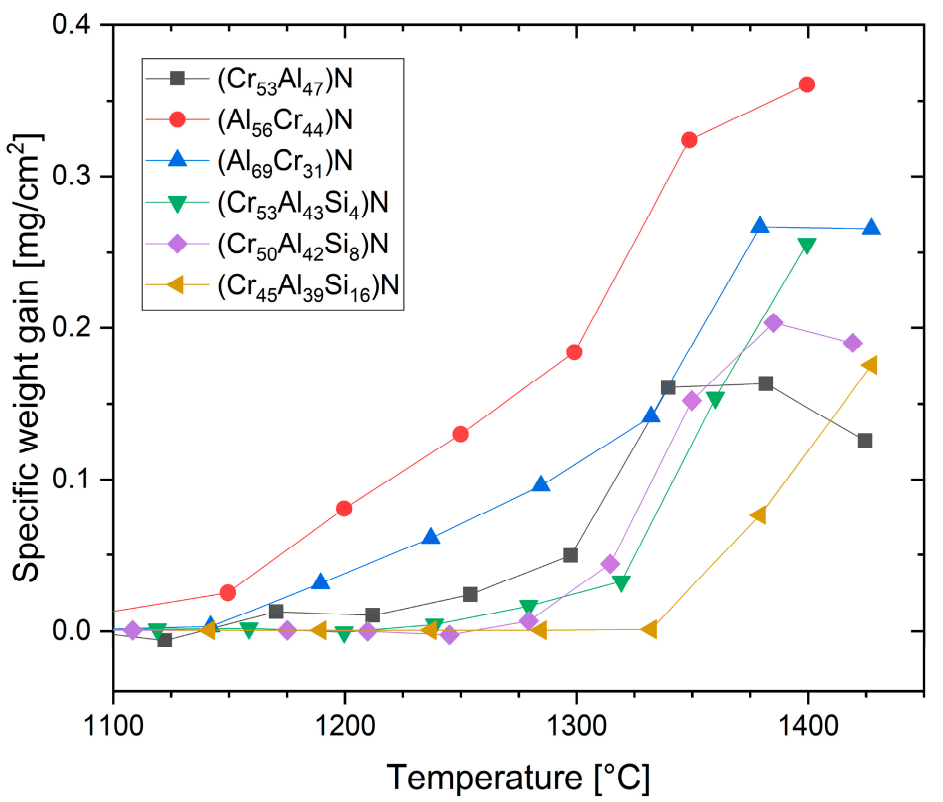

Figure 21. Weight gain measured by dynamic TGA measurements of fcc-structured (AlCr)N, (Al$\mathrm{CrSi}) \mathrm{N}$ and $(\mathrm{CrAl}) \mathrm{N},(\mathrm{CrAlSi}) \mathrm{N}$ coatings up to $1440{ }^{\circ} \mathrm{C}$ in synthetic air, redrawn after [119], original (C) American Vacuum Society. 
The (CrAlSi)N and (AlCrSi)N coatings can also be doped with one additional element to address modifications of various properties, e.g., O [132], Y [133] B [134], W [135,136], $\mathrm{Ni}$ [137], and others. Additionally, more than one element was added, e.g., Y and O [138]. Multilayer architectures were built using CrAlSiN and AlCrSiN combined, for example, with Si-free AlCrN layers [139], with AlSiN [140], or with coatings containing Si, such as Cr-doped AlSiN [127], with MoN, NbN [139], or with CrN [141], and others.

\subsection{Coatings with the Addition of Two or More Elements}

Quarternary and higher-order systems have been explored to further optimise coating properties. However, this has also been pursued from an industrial perspective dealing with patent issues to obtain unique selling points (USPs) or to supersede patents from competitors. However, the complexity quickly increases, and there is the potential for cross-reactions between the alloying elements. Even if the results achieved do not generally outperform the simpler coatings, a study of that research will reveal indicators of potential directions for coating development. A detailed discussion is beyond the scope of this paper; however, selected publications on Al-Cr based multinary coatings are listed below.

Si-Mo sputtered [142], Si-Ni sputtered [143,144], Si-Ti arc [145,146], Si-W arc [78,135], Si-W sputtered [136], Si-Ni sputtered [137], Si-C sputtered [133,147], Si-B sputtered [134], Si-Mg [148], Ti-C sputtered [114], MoCu sputtered [106], Si-Y-O sputtered [138], Ti-Si-Y arc [149], and Nb-Ti-Si sputtered [150].

In addition, even high-entropy coating modifications are the focus of R\&D activities $[150,151]$.

\section{Complex Coating Architectures}

Coatings used in industrial applications are seldom homogeneous monolayers, but often comprise several coating layers or complex architectures. This allows several functional requirements to be met through coating layers serving different functions, for example, good adhesion to the substrate material through a bonding layer, mechanical stability through a main layer, and tribological properties through a top layer. Furthermore, in nanocomposite or multilayered designs, the additional interfaces created can help to enhance performance, for example, by providing increased fracture resistance, beyond the properties of the individual layers. A multitude of approaches have been demonstrated for AlCrX-based coatings.

A schematic drawing of the main coating architectures is shown in Figure 22. It must be noted that the bond coat which is often applied essentially produces a two-layer coating that has not been considered explicitly in this overview.

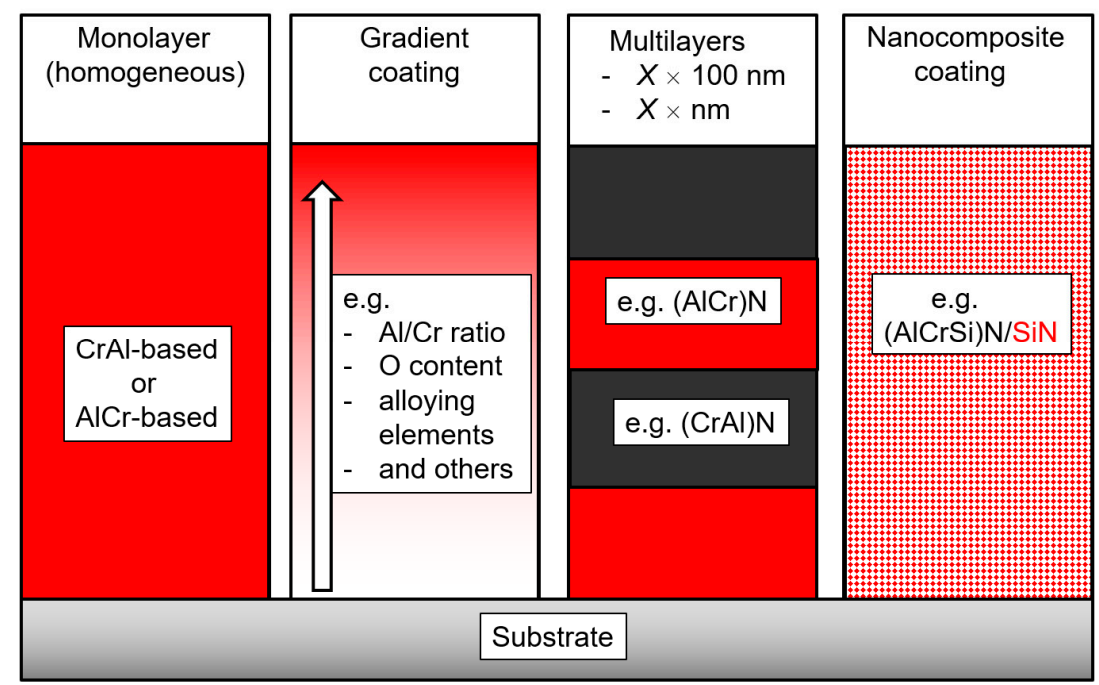

Figure 22. Main types of coating architectures. 
It should be mentioned that in practical coating designs, different architecture types are often mixed in one and the same coating, e.g., gradient coatings are predominantly realised more or less stepwise. The nanocomposite coating shown might be a part of the multilayer coating or part of the gradient coating. A primary example of a nanocomposite structure is the system (AlCrSi)N/a-SiN ${ }_{x}$, as discussed in Section 4.4.

\subsection{Multilayer and Nanomultilayer Coatings}

Multilayered coatings comprise at least two different layers, and most commonly this is a periodic repetition of two or more layers. The most frequently used is the classic ... A/B/A/B/A ... type of layering, where the same two layers are sequentially repeated. When the periodicity is within the size scale of up to a few tenths of nanometers, the terms nanomultilayers or nanolayered coatings are often used. The sublayers can be synthesised using different strategies. Keeping the same (nominal) coating chemistry, a variation of the process parameters, such as bias or deposition pressure, can be used to create layers of different stress states, for example. Changing the reactive gas composition is a further approach to alternate nitride, oxynitride and oxide layers on the same metal base, for example. Perhaps most common though is the combination of heterogeneous coating materials obtained through the inclusion of targets of different composition in the PVD deposition system. Furthermore, particularly in industrial-scale deposition systems, codeposition from spatially separated deposition sources with different target materials may be combined with substrate rotation to create multilayered coatings. There are a variety of different approaches for the materials used in the second single layers. Some examples are shown below.

\section{- CrAl-or AlCr-based structural multilayer}

The combination of fcc $(\mathrm{Al}, \mathrm{Cr}) \mathrm{N}$ with hcp $(\mathrm{Al}, \mathrm{Cr}) \mathrm{N}$ was investigated to address the potential for adapting stress, hardness and wear properties [88,96].

- CrAl-or AlCr-based combined with a binary nitride coating

The first publication dealt with ( $\mathrm{AlCr}$ ) N and CrN. One aim was to have a "ductile" coating similar to $\mathrm{CrN}$ combined with a high oxidation resistance. [19]. A combination with VN was utilised to improve the tribological behaviour at elevated temperatures [152-154]. $\mathrm{TiN} /(\mathrm{AlCr}) \mathrm{N}$ superlattices were deposited by sputtering. The coatings showed both an improved fracture toughness and hardness as compared to the monolayers [71].

\section{- $\quad$ CrAl-or AlCr-based combined with a ternary nitride coating}

The coating properties of $(\mathrm{AlCrX}) \mathrm{N}$ can be combined with AlTiN $[155,156]$. There are some coating systems that contain $\mathrm{V}$ in a nitride coating to tailor tribological properties (formation of lubricant oxides), such as (TiV)N [157], (CrV)N and (CrMo)N [103]. The combination with (TiSi)N is focused on high hardness and oxidation stability [158].

- CrAl-or AlCr-based combined with a quaternary nitride coating

The comination with quarternary nitride layers is a very complex approach. Many coating properties are influenced in parallel. The following systems have been explored: (AlTiSi)N [151,159], (AlCrSi)N [139,160], (TiTaAl)N [161].

\section{- CrAl-or AlCr-based combined with an oxynitride or oxide coating}

The arc deposition of an fcc-(Al,Cr)ON layer on top of an fcc-(Al,Cr)N-based coating resulted in improved wear resistance [162]. The combination of alternating single layers consisting of a nitride fcc- $\left(\mathrm{Al}_{x} \mathrm{Cr}_{1-x}\right) \mathrm{N}$ layer followed by an oxide coating $\left(\mathrm{Al}_{x} \mathrm{Cr}_{1-x}\right)_{2} \mathrm{O}_{3}$ with a hardness of up to $22 \mathrm{GPa}$ was demonstrated [163].

\subsection{Gradient Coatings}

Coating designs with gradient layers imply that coating properties change sequentially in the direction of the coating thickness. Frequently, the primary factor that is varied is the composition of the coating. Both the sputtering and arc deposition methods are used 
to generate compositional gradients continuously or stepwise. Two examples of coatings with a Si gradient in which the layer containing less silicon is at the bottom and the layer with more silicon is at the top are shown to demonstrate this.

In the first example, CrAlSiN monolayers (0, 4, 1.8, 5.9, 8.5 at.\% Si) and CrAlSiN coatings with a continuous $\mathrm{Si}$ gradient $(\mathrm{Cr} / \mathrm{Al}$ ca. 1.6) were deposited by co-sputtering using elemental targets of $\mathrm{Cr}, \mathrm{Si}$, and $\mathrm{Al}$ with a $\mathrm{Si}$ content of 5 and 8 at.\% in the top layer and were compared with (CrAlSi)N monolayers [122]. The authors described the formation of a nanocomposite (CrAlSi)N/a-SiN $x$ structure for monolayer coatings with a Si content of $5.9, \mathrm{Cr}_{23.4} \mathrm{Alr}_{15.6} \mathrm{Si}_{5.9} \mathrm{~N}_{53.8} \mathrm{O}_{1.3}$, or higher by means of an X-ray diffraction pattern and for 8.5 at.\% Si as well using TEM examinations. The gradient coatings exhibited higher toughness in terms of scratch/crack propagation resistance relative to monolayers with comparable Si content.

In the second example, (AlCrSi)N coatings were arc deposited using cathodes of $\mathrm{Al}_{70} \mathrm{Cr}_{30}$ and $\mathrm{Al}_{60} \mathrm{Cr}_{30} \mathrm{Si}_{10}$ as a gradient coating for the Si content [121,125]. Different levels of $\mathrm{Si}$ content were achieved by adjusting the number of cathodes per coating deposition step. The coatings containing $\mathrm{Si}$ showed a nanocomposite structure $(\mathrm{AlCrSi}) \mathrm{N} / \mathrm{a}-\mathrm{SiN} \mathrm{N}_{x}$ in all compositional regions. Cutting tests showed that the gradient coating provided better performance than the pure $\left(\mathrm{Al}_{70} \mathrm{Cr}_{30}\right) \mathrm{N}$ coating $[121,125]$.

Coating designs with a gradient on the $\mathrm{O}$ content were realised by arc deposition in the top layer region of a part for solar energy thermal conversion in the form of $(\mathrm{AlCr}) \mathrm{N} /(\mathrm{AlCr}) \mathrm{NO} /(\mathrm{AlCr}) \mathrm{O}$. The functional coating properties indicate that this coating with its characteristic of selective absorption is a candidate for photo-thermal conversion at high temperatures [164].

\section{From ( $\mathrm{CrAl}) \mathrm{N}$ or $(\mathrm{AlCr}) \mathrm{N}$ to Oxynitride and Oxide Coatings}

The special features of the $\mathrm{MeN}_{1-x} \mathrm{O}_{x}$ coating arise from the addition of oxygen to $\mathrm{MeN}$, which results in coating properties between those of metal nitrides, MeN, and those of the insulating oxides, MeO [165]. Tuning the oxygen/nitrogen ratio allows the physical, mechanical and tribological characteristics to be tailored. For AlCr-based coatings, both oxynitrides as well as pure oxide coatings of $\mathrm{AlCr}$ are of interest. It was shown that oxynitride and oxide coatings (alpha and cubic crystal modifications) have a potential for use in various tribological applications and for oxidation protection [166-170], and moreover, even for use in solar absorbers [171]. Both vacuum arc deposition and various sputtering methods, including HiPIMS processes and hybrid processes (HiPIMS plus DC magnetron sputtering), were applied to investigate coatings of the types ( $\mathrm{AlCr}) \mathrm{ON}$ and (AlCr)O [23,172-175].

In the context of oxynitrides, it should be noted that in many industrialised nitride deposition processes, residual amounts of oxygen (up to several at.\%) are incorporated [111, $122,146,172,175,176]$. The effects of substrate rotation additionally influence details of the structure due to the changing position in the chamber relative to the source [132]. These effects occur in industrial coating systems and are frequently not discussed. However, for example, it was observed that a small amount of oxygen can decrease the hardness of nanocomposites significantly [177]. A detailed discussion of these effects is beyond the scope of this paper. However, actively controlling oxygen content in the coatings is a potent modifier of structure and properties, as will be exemplified in this section.

Oxynitride coatings and oxide coatings have often been investigated in one and the same paper. Figure 23 shows a schematic representation of the phase evolution in $(\mathrm{CrAl}) \mathrm{NO}$ and $(\mathrm{AlCr}) \mathrm{NO}$ systems dependent on $\mathrm{Cr} /(\mathrm{Al}+\mathrm{Cr})$ and $\mathrm{O} /(\mathrm{O}+\mathrm{N})$ at a typical deposition temperature of about $500-600{ }^{\circ} \mathrm{C}$ based on results from $[166,167,172,173,178]$. The differentiation between $\mathrm{Cr}$-rich and $\mathrm{Al}$-rich coating types is ignored here in the interest of facilitating visual perception. 


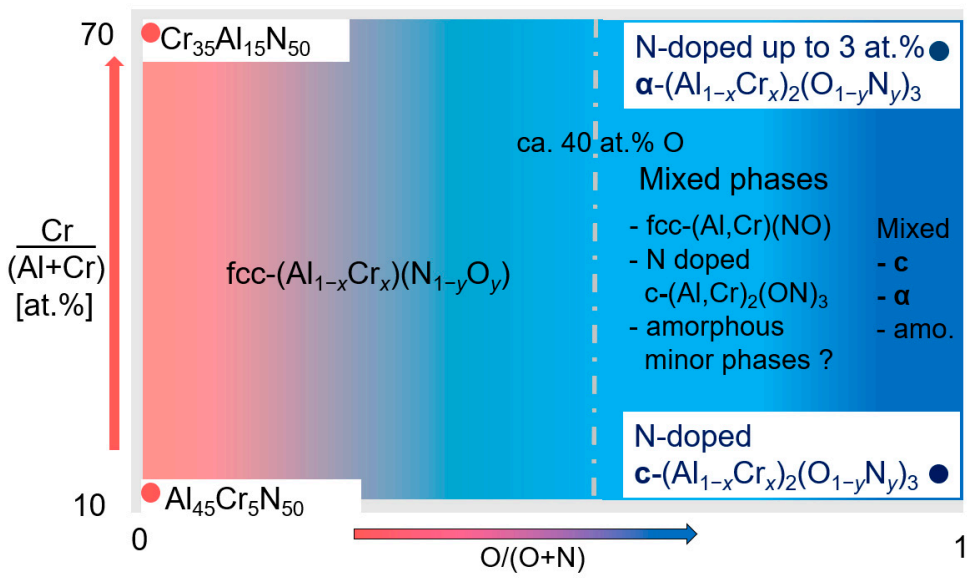

Figure 23. Schematic representation of phase evolution in the (AlCr)NO system dependent on $\mathrm{Cr} /(\mathrm{Al}$ $+\mathrm{Cr})$ and $\mathrm{O} /(\mathrm{O}+\mathrm{N})$ at a deposition temperature in the range of about $500-600{ }^{\circ} \mathrm{C}, \mathrm{c}=$ cubic structure, amo. $=$ amorphous structure.

Oxynitrides are formed up to an estimated oxygen content of about 40 at.\%. Above this threshold, a mixed phase structure is formed, consisting of oxynitrides and oxide phases as well as sometimes a minor fraction of amorphous phases as well. At high oxygen contents, oxides are formed. A cubic oxide structure (gamma or fcc) grows at a low $\mathrm{Cr} /(\mathrm{Cr}+\mathrm{Al})$ content, whereas a hexagonal oxide structure (alpha) is predominant at a higher $\mathrm{Cr} /(\mathrm{Cr}+\mathrm{Al})$ content. The formation of an oxide coating structure with a dominating fcc phase has also been reported a number of times $[166,179,180]$. The lowest reported value to obtain a pure corundum phase was $\mathrm{Cr} /(\mathrm{Cr}+\mathrm{Al})=0.3$ [178]. There are also several reports on the existence of minor amorphous phases $[175,178,179]$.

Selected results will be presented in more detail for the two deposition methods, arc and sputtering.

\subsection{Arc Evaporation: Oxynitride and Oxide Coatings}

One of the earliest approaches to synthesising oxides by arc evaporation is reported in a patent application (1992) from Schulz and Bergmann for the deposition of $\alpha-\mathrm{Al}_{2} \mathrm{O}_{3}$ type coatings by DC arc evaporation at a lower temperature than in CVD (Chemical Vapor Deposition) processes, when the $\mathrm{Al}$ is doped using $\mathrm{Cr}$ or other selected elements [22]. The field, however, remained relatively unexplored well into the 2000s.

Investigations of coatings containing $\mathrm{Al}, \mathrm{Cr}, \mathrm{O}$ and $\mathrm{N}$ deposited by the vacuum arc method using different cathode compositions $(\mathrm{Al} / \mathrm{Cr})$ and different reactive gas compositions $\left(\mathrm{N}_{2} / \mathrm{O}_{2}\right)$ are shown in Figure 24 .

Upon increasing the oxygen fraction in the gas flow, first an oxynitride is formed, followed by an N-doped oxide and then a pure oxide [166]. Different phases are formed depending on the oxygen content in the reactive gas and the metal composition of the cathodes. In oxynitride coatings, the phase composition is first predominantly cubic, then a mixed zone is observable, comprising the solid solutions fcc $(\mathrm{Cr}, \mathrm{Al}) \mathrm{N}$, and nitrogen-doped cubic $(\mathrm{Cr}, \mathrm{Al})_{2} \mathrm{O}_{3}$ (gamma or fcc) or, finally, $\alpha(\mathrm{Cr}, \mathrm{Al})_{2} \mathrm{O}_{3}$ at a pure oxygen flow. The oxide structures formed were either cubic or $\alpha(\mathrm{Cr}, \mathrm{Al})_{2} \mathrm{O}_{3}$. Figure 25 shows the tendencies for the formation of either cubic or $\alpha(\mathrm{Cr}, \mathrm{Al})_{2} \mathrm{O}_{3}$. 
(a)

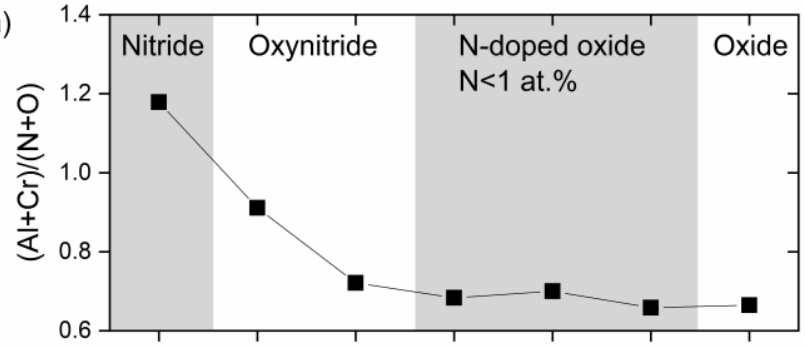

(b)

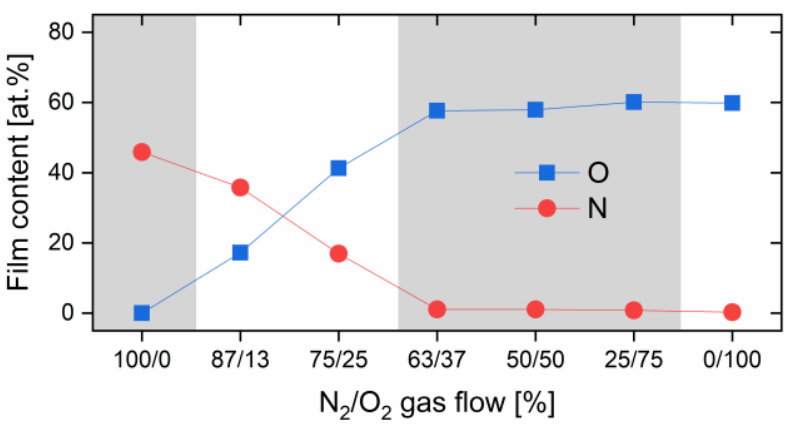

Figure 24. (a) $\mathrm{Al}+\mathrm{Cr}$ to $\mathrm{N}+\mathrm{O}$ ratio (b) $\mathrm{N}$ and $\mathrm{O}$ content in Al-Cr-O-N coatings for different $\mathrm{N}_{2} / \mathrm{O}_{2}$ reactive gas mixtures, redrawn after [166], original (c) Elsevier.

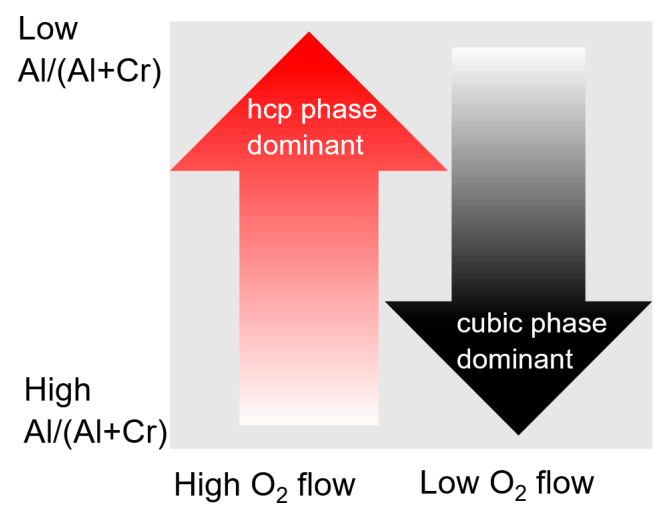

Figure 25. Schematic representation of the influence the coating composition has on the trend of phase formation in $(\mathrm{AlCr})_{2} \mathrm{O}_{3}$, redrawn after [166], original @ Elsevier.

A low level of $\mathrm{O}$ and a high $\mathrm{Al}$ content (e.g., using cathodes of $\mathrm{Al}_{66} \mathrm{Cr}_{34}$ ) in the coatings results in the formation of cubic $(\mathrm{Cr}, \mathrm{Al})_{2} \mathrm{O}_{3}$ layers. Higher levels of $\mathrm{O}$ and $\mathrm{Cr}$ (e.g., using cathodes of $\mathrm{Cr}_{75} \mathrm{Al}_{25}$ ) in the coatings increase the probability of the deposition of $\alpha$ $(\mathrm{Cr}, \mathrm{Al})_{2} \mathrm{O}_{3}$ layers.

The $\mathrm{Cr}$-rich $(\mathrm{CrAl}) \mathrm{O}$ coatings show the highest hardness values of 31-34 GPa, while the Al-rich coatings have lower values of 24-28 GPa. Metal cutting tests using cemented carbide inserts in turning operations showed good wear properties for mainly oxygen-rich coatings. These results were better than with the presence of the corundum phase of the oxide. Fcc- $(\mathrm{Cr}, \mathrm{Al})_{2} \mathrm{O}_{3}$ dominated coatings have also been shown to have wear properties similar to those of $\alpha-(\mathrm{Cr}, \mathrm{Al})_{2} \mathrm{O}_{3}$ coatings [166].

In conclusion, the ideal structure is a corundum-type solid solution, preferably with a high $\mathrm{Al}$-content ( $>60$ at. $\%$ on the metal sublattice). However, at a high Al-content, the tendency towards the formation of dual-phase compositions containing metastable phase fractions has been observed, which may negatively influence the mechanical properties and performance. The authors concluded that the cathodic arc evaporation of $(\mathrm{Al}, \mathrm{Cr})_{2} \mathrm{O}_{3}$-based coatings is very complex when the microstructure of the arc cathode used is included as a factor [174].

In combination with $(\mathrm{AlCr}) \mathrm{N}$, a small addition of $\mathrm{O}$ using $\mathrm{Al}_{70} \mathrm{Cr}_{30}$ in the top layer of a double layer coating $((\mathrm{AlCr}) \mathrm{N} /(\mathrm{AlCr}) \mathrm{NO})$ has been reported to increase the service life 
of tools in milling applications [181]. The effect of the oxygen content in doped $\mathrm{AlCr}$ based coatings, e.g., (AlCrSi)N, has also been investigated [132].

It should be mentioned that a special pulsed arc process, the $\mathrm{P} 3 \mathrm{e}^{\mathrm{TM}}$, was developed to prevent oxide contaminations of the cathodes and increase the reactivity of the metal vapour and reactive gas [23].

\subsection{Sputtering: Oxynitride and Oxide Coatings}

The deposition of AlCr-based oxynitride and oxide coatings through sputtering has been approached using both RF-sputtering $[173,179,182,183]$ as well as HiPIMS techniques $[170,175]$. Systematic investigations of RF-sputtered Al-Cr-O-N coatings have shown that, depending on the gas composition $\left(\mathrm{Ar}, \mathrm{O}_{2}, \mathrm{~N}_{2}\right)$, the total gas pressure and the $\mathrm{Al} / \mathrm{Cr}$ ratio, coatings with a single phase or mixed phase are grown. These are a corundum-type $\alpha-\left(\mathrm{Al}_{1-x}, \mathrm{Cr}_{x}\right)_{2}\left(\mathrm{O}_{1-y}, \mathrm{~N}_{y}\right)_{3}$ structure and a CrN-type fcc- $\left(\mathrm{Al}_{1-x}, \mathrm{Cr}_{x}\right)\left(\mathrm{O}_{1-y}, \mathrm{~N}_{y}\right)$ structure, as well as a mixed-phase composition of both single phases $[173,183]$. The corundum phase can contain up to 3 at. $\%$ nitrogen $[138,183]$.

The coating composition and structure with a given sputtering target composition are strongly dependent on the sputtering mode. Different $\mathrm{Al} / \mathrm{Cr}$ ratios, deposition rates, and oxygen contents were reported for the comparison of DC magnetron, HiPIMS and a hybrid mode employing both [175]. Thick oxynitride coatings, thicker than $35 \mu \mathrm{m}$, were deposited by gas-flow sputtering [170].

\section{Selected Industrial Coating Types and Main Applications}

A large number of commercial coating solutions involving AlCr-based coatings are offered by PVD system manufacturers, job coating service centres and by tool and part manufacturers worldwide. The chemical compositions and the coating architectures vary, as do the deposition technologies and coating processes used. In the dominant arc source technology, the magnetic field set-up is particularly important as it influences the plasma conditions and coating properties. Within the group of sputtering technologies, a a great many more parameters can be varied, particularly in HiPIMS processes, e.g., pulse form and length.

The functionality of the coating-substrate system results from the quality and reproducibility of the whole process chain. Proper selection of the pre-treatment processing of the parts, for example, the cutting edges of cutting tools, is essential and must be carried out outside the coating chamber prior to deposition. Ion etching processing of the parts is performed to remove surface contamination and obtain sufficient coating adhesion. Process parameters are selected to manage stress in the coating. For commercial reasons, the process details are typically protected by the companies offering $\mathrm{CrAl}$ - and $\mathrm{AlCr}$-based coatings.

It must be pointed out that a new challenge, that of sustainable surface engineering, e.g., the minimisation of energy consumption, the selection of the coating material, reducing waste, and facilitating recycling, is attracting increasing interest. A comprehensive overview of all types of commercial AlCr-based coatings is beyond the scope of this review. However, a brief introduction to the application field of AlCr-based coatings will be provided through a characterisation of three different coating types.

\subsection{Examples for Industrially Applied Coatings Types}

Within the authors' company, more than 10 variations of AlCr-based coatings have been or are in use (different coating thicknesses and other minor variations are not counted). As an example of the technology status, three coating types will be roughly characterised to highlight features of the deposition process and the coating property ranges. Selected coating properties are shown in Table 3. Two deposition methods are applied: arc and HiPIMS (S3p). The coatings have different alloying elements and various architectures. 
Table 3. Brief characteristics of selected industrially applied AlCrN-based coating types.

\begin{tabular}{|c|c|c|c|}
\hline Feature & $\begin{array}{c}\text { Monolayer Arc } \\
\text { (e.g., BALINIT }{ }^{\circledR} \text { ALCRONA PRO) }\end{array}$ & $\begin{array}{c}\text { Multilayer } \\
\text { (e.g., BALINIT }{ }^{\circledast} \text { HELICA) }\end{array}$ & $\begin{array}{c}\text { Monolayer Sputtering } \\
\text { (e.g., BALIQ }{ }^{\circledR} \text { ALCRONOS) }\end{array}$ \\
\hline Source type & Magnetic steered arc & Magnetic steered arc & Magnetron optimised for S3p (HiPIMS) \\
\hline Cathode type/form & Powder metallurgical/circular & Powder metallurgical and vacuum melting/circular & Powder metallurgical/circular \\
\hline Coating temp. $\left[{ }^{\circ} \mathrm{C}\right]$ & $400-500^{\circ} \mathrm{C}$ & $400-500^{\circ} \mathrm{C}$ & $400-500^{\circ} \mathrm{C}$ \\
\hline Chemical composition & $\begin{array}{r}\mathrm{Al}>\mathrm{Cr} \text { content at. } \% \\
\text { stoichiometric } \mathrm{N} \text { content }\end{array}$ & $\begin{array}{ll} & \text { Layer A: like monolayer } \\
\text { - } & \text { Layer B: e.g., TiSi } \\
\text { - } & \text { stoichiometric N content }\end{array}$ & $\begin{array}{r}\mathrm{Al}>\mathrm{Cr} \text { content at.\% } \\
\text { - } \quad \text { stoichiometric N content }\end{array}$ \\
\hline Alloying types & $\begin{array}{ll}- & \text { metals, e.g., } \mathrm{W}, \mathrm{Mg} \\
- & \text { metalloids, e.g., } \mathrm{Si}, \mathrm{B} \\
- & \text { metal + metalloid }\end{array}$ & - & $\begin{array}{ll}- & \text { metals, e.g., } \mathrm{W}, \mathrm{Mg} \\
- & \text { metalloids, e.g., } \mathrm{Si}, \mathrm{B} \\
- & \text { metal + metalloid }\end{array}$ \\
\hline $\begin{array}{l}\text { Coating hardness/Indentation E-modul range } \\
\text { [GPa] }\end{array}$ & $\begin{array}{c}29-37 \\
390-420\end{array}$ & $\begin{array}{c}32-39 \\
380-410\end{array}$ & $\begin{array}{c}31-38 \\
370-430\end{array}$ \\
\hline $\begin{array}{l}\text { Thickness [um] } \\
\text { Speciality }\end{array}$ & $\begin{array}{c}0.5-6 \\
\text { Universal use }\end{array}$ & $\begin{array}{c}1-4 \\
\text { High hardness }\end{array}$ & $\begin{array}{c}0.5-5 \\
\text { Low defect density, smooth }\end{array}$ \\
\hline
\end{tabular}


The first coating type is a monolayer deposited by cathodic vacuum arc (e.g., BALINIT ${ }^{\circledR}$ ALCRONA PRO). The second coating type is a multilayer coating employing the layer sequence $(\mathrm{AlCr}) \mathrm{N} /(\mathrm{TiSi}) \mathrm{N}$ (e.g., BALINIT ${ }^{\circledR}$ HELICA), also applied by arc deposition. The third coating type is a monolayer sputter coating deposited using an advanced HiPIMS process (S3p), which can also be employed for multilayers.

The coating morphologies are shown in the cross-sectional images obtained by SEM together with a ball crater. The fine columnar structure of the arc monolayer $(\mathrm{AlCr}) \mathrm{N}$ is shown in Figure 26.

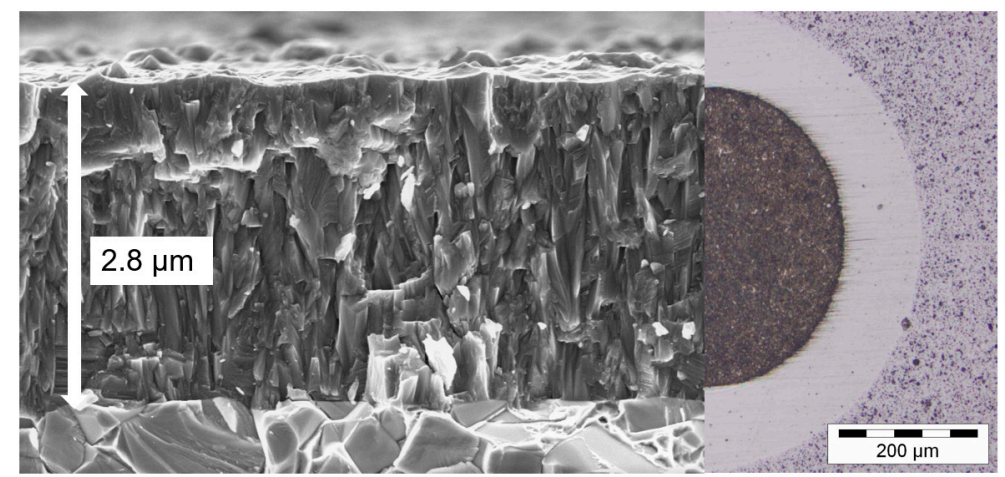

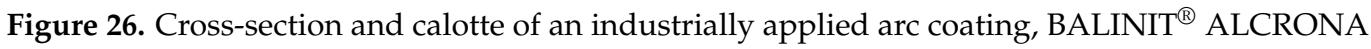
PRO, courtesy of Oerlikon Balzers.

The fine-grained morphology of an arc multilayer $(\mathrm{AlCr}) \mathrm{N} /(\mathrm{TiSi}) \mathrm{N}$ is demonstrated in Figure 27. This is a classical multilayer deposited by alternated switching on the sources with the different cathode materials. The added (TiSi)N sublayers increase the hardness of the coating.

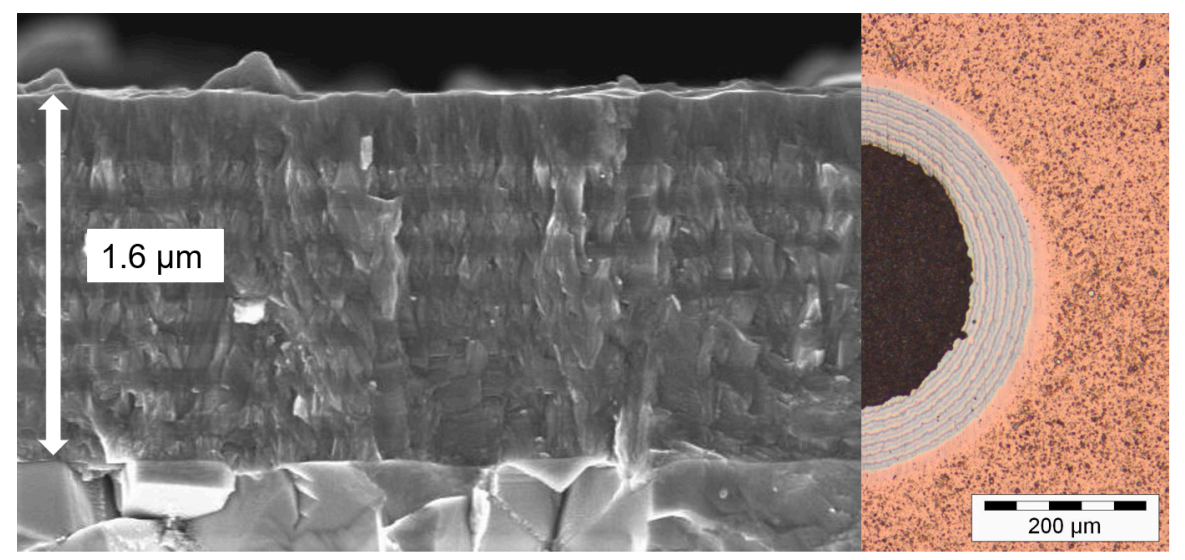

Figure 27. Cross section and calotte of an industrially applied arc multilayer coating (AlCr)N/(TiSi)N, with top layer of (TiSi)N, BALINIT ${ }^{\circledR}$ HELICA, courtesy of Oerlikon Balzers.

The dense columnar structure with a low defect density and high smoothness of HiPIMS (AlCr)N monolayers is clearly seen in Figure 28. This coating is particularly advantageous for micro tools and other small parts that are sensitive to droplets in arcdeposited coatings. 


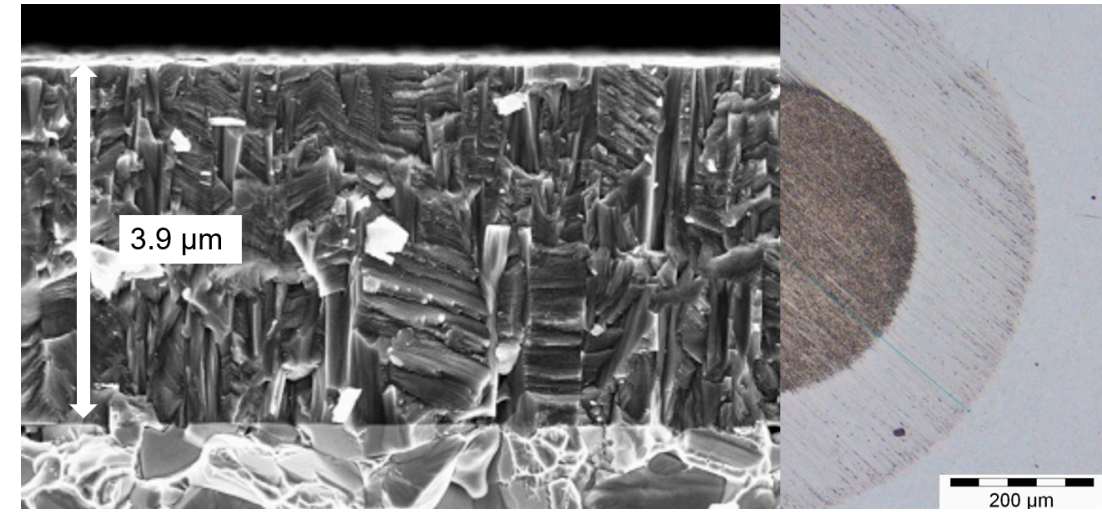

Figure 28. Cross-section and calotte of an industrially applied HiPIMS (S3p) (AlCr)N coating, BALIQ ${ }^{\circledR}$ ALCRONOS, courtesy of Oerlikon Balzers.

\subsection{Typical Application Fields of AlCr-Based Coatings}

Applications for $\mathrm{AlCr}$-based coatings cover a wide range of cutting tools and forming tools, but also components. The dominant application is for tools [67,149,184-188]. Figure 29 shows examples of tool applications. Besides the standard applications, additional application potentials must be considered as well. Examples of this are: extremely thick coatings of more than $30 \mu \mathrm{m}$ for turbine blades [170], or multilayer coatings with an oxygen gradient for solar absorbers [164].

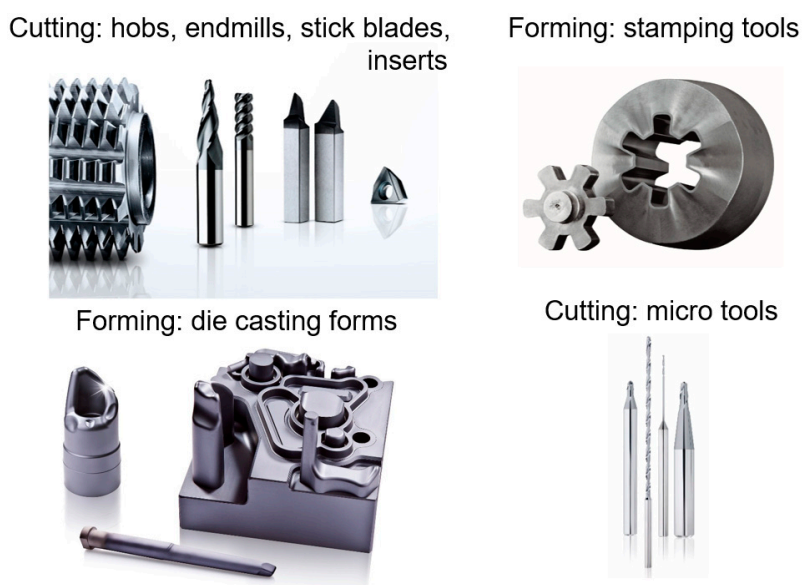

Figure 29. Selected tool applications for AlCr-based coatings, courtesy of Oerlikon Balzers.

\section{Summary and Outlook}

$(\mathrm{Cr}, \mathrm{Al}) \mathrm{N}$ and $(\mathrm{Al}, \mathrm{Cr}) \mathrm{N}$ coatings are amongst the main PVD coatings in commercial applications and offer a high degree of freedom to tailor the coating structure and properties by controlling the chemical composition and tuning the deposition process parameters. The coating architectures which can be achieved range from simple monolayers to heterogenous multilayers combining $\mathrm{AlCr}$-based layers with other material systems. The present status and current trends can be summarised briefly as follows:

1. Besides arc, HiPIMS deposition methods will also be used more and more in addition to arc evaporation.

2. Alloying to adapt coating properties makes use of at least one element from the metals, metalloids or rare earth elements.

3. The main alloying element presently in use is silicon.

4. The variety in alloying will continue to increase to optimise coatings for dedicated applications. 
5. The addition of oxygen offers a possibility for tuning properties, e.g., tribological and optical.

6. Multilayer architectures, including nano multilayers, are increasingly being applied in combination with binary, ternary and quaternary hard coatings.

7. Besides AlTi-based coatings, $\mathrm{CrAl}$ - and $\mathrm{AlCr}$-based coatings are the predominant coating type applied to tools.

8. More and more general engineering parts will be coated in addition to tools, also with thicker coatings.

9. Sustainability aspects (sustainable surface engineering) will be taken into account, for example, selecting a specific alloying element, minimising the environmental impact in the production of the coating, the use of the coating, and recycling.

Funding: This research received no external funding.

Institutional Review Board Statement: Not applicable.

Informed Consent Statement: Not applicable.

Acknowledgments: The authors are thankful for the input received and the fruitful discussions enjoyed with all of our Oerlikon Balzers colleagues, including Jürgen Ramm, Arnd Müller, Ali Khatibi, Siegfried Krassnitzer, Denis Kurapov, and Hossein Najafi (Oerlikon Metco). In addition, the authors also wish to thank Christian Mitterer (Montanuniversität Leoben, Austria), Paul Mayrhofer (TU Vienna, Christian Doppler Laboratories, Austria) and Michael Stüber (KIT, Karlsruhe, Germany) for their constructive input in the form of discussions.

Conflicts of Interest: The authors declare no conflict of interest.

\section{References}

1. Aksenov, I.I.; Andreev, A.A. Vacuum arc coating technologies at NSC KIPT. Probl. At. Sci. Technol. Ser. Plasma Phys. 1999, 3 , 242-246.

2. Vogel, J. Harte Schichten, Goldene Zeiten (Hard Coatings, Golden Times); Informationsmappe; Oerlikon-Bührle Holding AG: Zurich, Switzerland, 1982; Volume 5004.

3. Sue, J.A.; Perry, A.J.; Vetter, J. Young's modulus and stress of CrN deposited by cathodic vacuum arc evaporation. Surf. Coat. Technol. 1994, 68, 126-130. [CrossRef]

4. Vetter, J. Vacuum arc coatings for tools: Potential and application. Surf. Coat. Technol. 1995, 76, 719-724. [CrossRef]

5. Vetter, J. 60 years of DLC coatings: Historical highlights and technical review of cathodic arc processes to synthesize various DLC types, and their evolution for industrial applications. Surf. Coat. Technol. 2014, 257, 213-240. [CrossRef]

6. Vetter, J.; Burgmer, W.; Dederichs, H.G.; Perry, A.J. The architecture and performance of multilayer and compositionally gradient coatings made by cathodic arc evaporation. Surf. Coat. Technol. 1993, 61, 209-214. [CrossRef]

7. PalDey, S.; Deevi, S.C. Single layer and multilayer wear resistant coatings of (Ti,Al)N: A review. Mater. Sci. Eng. A 2003, 342, 58-79. [CrossRef]

8. Vetter, J. $\left(\mathrm{Al}_{x}: \mathrm{Ti}_{y}\right) \mathrm{N}$ coatings deposited by cathodic vacuum arc evaporation. J. Adv. Mater. 1999, 31, 41-47.

9. Andersson, J.M.; Vetter, J.; Müller, J.; Sjölén, J. Structural effects of energy input during growth of $\mathrm{Ti}_{1-x} \mathrm{Al}_{x} \mathrm{~N}(0.55 \leq \mathrm{x} \leq 0.66)$ coatings by cathodic arc evaporation. Surf. Coat. Technol. 2014, 240, 211-220. [CrossRef]

10. Tanaka, Y.; Ichimiya, N.; Onishi, Y.; Yamada, Y. Structure and properties of Al-Ti-Si-N coatings prepared by the cathodic arc ion plating method for high speed cutting applications. Surf. Coat. Technol. 2001, 146, 215-221. [CrossRef]

11. Donohue, L.A.; Smith, I.J.; Münz, W.-D.; Petrov, I.; Greene, J.E. Microstructure and oxidation resistance of $\mathrm{Ti}_{1-x-y-z} \mathrm{Al}_{x} \mathrm{Cr}_{y} \mathrm{Y}_{z} \mathrm{~N}$ layers grown by combined steered arc/unbalanced magnetron- sputter deposition. Surf. Coat. Technol. 1997, 94, $226-231$. [CrossRef]

12. Vetter, J.; Krug, T.; von der Heide, V. AlTiCrNO coatings for dry cutting deposited by reactive cathodic vacuum arc evaporation. Surf. Coat. Technol. 2003, 174, 615-619. [CrossRef]

13. Vetter, J.; Ishikawa, T.; Shima, N. Nanocomposite AlTiNCO coatings deposited by reactive cathodic arc evaporation. Plasma Process. Polym. 2007, 4, S668-S672. [CrossRef]

14. Knotek, O.; Atzor, M.; Barimani, C.; Jungblut, F. Development of low temperature ternary coatings for high wear resistance. Surf. Coat. Technol. 1990, 42, 21-28. [CrossRef]

15. Hoffmann, S.; Jehn, H.A. Oxidation behaviour of $\mathrm{CrN}_{x}$ and $(\mathrm{Cr}, \mathrm{Al}) \mathrm{N}$ hard coatings. Werkst. Korros. 1990, 47, 756-760. [CrossRef]

16. Schulze, D.; Wilberg, R.; Fleischer, W.; Lunow, T. Multicomponent Hard Thin Films Deposited by Hollow Cathode Arc Evaporator (HCA). In Proceedings of the International Conference on Metallurgical Coatings and Thin Films, San Diego, CA, USA, 2-6 April 1990.

17. Knotek, O.; Löffler, F.; Scholl, H.J. Properties of arc-evaporated CrN and (Cr,Al)N. Surf. Coat. Technol. 1991, 45, 53-58. [CrossRef] 
18. Knotek, O.; Löffler, F.; Scholl, H.J.; Barimani, C. The multisource arc process for depositing ternary Cr- and Ti-based Coatings. Surf. Coat. Technol. 1994, 68, 309-313. [CrossRef]

19. Vetter, J.; Lugscheider, E.; Guerreiro, S.S. (Cr:Al)N coatings deposited by the cathodic vacuum are evaporation. Surf. Coat. Technol. 1998, 98, 1233-1239. [CrossRef]

20. Ishikawa, T.; Fuji, F. Improvement of the Cutting Performance of TiSiN Coated Cemented Carbide-Tools. In Proceedings of the 34th International Conference and Metallurgical Coatings and Thin Films ICMCTF, San Diego, CA, USA, 23-27 April 2007; p. B6-1-8.

21. Li, W.; Liu, P.; Meng, J.; Zhang, K.; Ma, F.; Liu, X.; Chen, X.; He, D. Microstructure and mechanical prop erty of TiSiN nanocomposite film with inserted CrAlN nanomultilayers. Surf. Coat. Technol. 2016, 286, 313-318. [CrossRef]

22. Schulz, H.; Bergmann, E. Hard Layer, Work Piece Coated with Such a Layer and Process for Coating with the Layer. EP 513,662. 11 November 1992.

23. Ramm, J.; Ante, M.; Bachmann, T.; Widrig, B.; Brändle, H.; Döbeli, M. Pulse enhanced electron emission (P3e $\left.\mathrm{e}^{\mathrm{TM}}\right)$ arc evaporation and the synthesis of wear resistant Al-Cr-O coatings in corundum structure. Surf. Coat. Technol. 2007, 202, 876-883. [CrossRef]

24. Boxman, R.L.; Philip, J.M.; David, M.S. Handbook of Vacuum Arc Science and Technology: Fundamentals and Applications, 1st ed.; Noyes Publications: Park Ridge, NJ, USA, 1995.

25. Anders, A. Cathodic Arcs: From Fractal Spots to Energetic Condensation; Springer: New York, NY, USA, 2008.

26. Anders, A. A review comparing cathodic arcs and high power impulse magnetron sputtering (HiPIMS). Surf. Coat. Technol. 2014, 257, 308-325. [CrossRef]

27. Vetter, J. PVD processes for depositing wear- and friction- reducing and decorative coatings. In Handbook of Thermoprocessing Technologies; Beneke, F., Nacke, B., Pfeifer, H., Eds.; Vulkan-Verlag Eifel: Essen, Germany, 2015; pp. 661-692.

28. Vetter, J. Surface treatments for automotive applications. In Coating Technology for Vehicle Applications; Cha, S.C., Erdemir, A., Eds.; Springer: Cham, Switzerland, 2015; pp. 91-132.

29. Vetter, J.; Kubota, K.; Isaka, M.; Mueller, J.; Krienke, T.; Rudigier, H. Characterization of advanced coating architectures deposited by an arc-HiPIMS hybrid process. Surf. Coat. Technol. 2018, 350, 154-160. [CrossRef]

30. Vetter, J.; Berger, M.; Derflinger, V.; Krassnitzer, S. Plasma-Assisted Coating Processes. Available online: https:/ / www.oerlikon. $\mathrm{com} /$ balzers/com/en/portfolio/surface-technologies/plasma-assisted-coating-processes-new-pvd-and-cvd-book/ (accessed on 12 February 2020).

31. Lundin, D.; Minea, T.; Gudmundsson, T. High Power Impulse Magnetron Sputtering: Fundamentals, Technologies, Challenges and Applications; Elsevier Science: Amsterdam, The Netherlands, 2019.

32. Ide, Y.; Inada, K.; Nakamura, T. Formation of Al-Cr-N films by an activated reactive evaporation (ARE) method. High Temp. Mater. Process. 2000, 19, 265-274. [CrossRef]

33. Schulze, D.; Wilberg, R. Multicomponent hard thin films deposited by hollow cathode arc evaporator (HCA). In Proceedings of the 4th joint International Symposium on Trends and New Applications in Thin Films TATF '94 and the 11th Conference om High Vacuum, Interfaces and Thin Films HVITF ‘94; DGM-Informationsges: Chemnitz, Germany, 1994.

34. Holzherr, M.; Falz, M.; Schmidt, T. Influence of hollow cathode plasma on AlCrN-thin film deposition with vacuum arc evaporation sources. Surf. Coat. Technol. 2008, 203, 505-509. [CrossRef]

35. Park, I.W.; Kang, D.S.; Moore, J.J.; Kwon, S.C.; Rha, J.J.; Kim, K.H. Microstructures, mechanical properties, and tribological behaviors of Cr-Al-N, Cr-Si-N, and Cr-Al-Si-N coatings by a hybrid coating system. Surf. Coat. Technol. 2007, 201, 5223-5227. [CrossRef]

36. Anders, A. Ion charge state distributions of vacuum arc plasmas: The origin of species. Phys. Rev. E 1997, 55, 969-981. [CrossRef]

37. Vetter, J.; Müller, J.; Erkens, G. Domino platform: PVD coaters for arc evaporation and high current pulsed magnetron sputtering. IOP Conf. Ser. Mater. Sci. Eng. 2012, 39, 012004. [CrossRef]

38. Vetter, J. Entwicklung und Erprobung von Beschichtungen für Stanz-, Zieh- und Prägewerkzeuge für die Schmiermittelarme und Schmiermittelfreie Fertigung; Final Report of Joint Project 13N6271; Metaplas Ionon GmbH: Bergisch Gladbach, Germany, 1996.

39. Kawate, M.; Kimura, A.; Suzuki, T. Microhardness and lattice parameter of $\mathrm{Cr}_{1-x} \mathrm{Al}_{x} \mathrm{~N}$ films. J. Vac. Sci. Technol. A 2002, 20, 569-571. [CrossRef]

40. Kawate, M.; Hashimoto, A.K.; Suzuki, T. Oxidation resistance of $\mathrm{Cr}_{1-x} \mathrm{Al}_{x} \mathrm{~N}$ and $\mathrm{Ti}_{1-x} \mathrm{Al}_{x} \mathrm{~N}$ films. Surf. Coat. Technol. 2003, 165, 163-167. [CrossRef]

41. Bagcivan, N.; Bobzin, K.; Theiß, S. $\left(\mathrm{Cr}_{1-x} \mathrm{Al}_{x}\right) \mathrm{N}$ : A comparison of direct current, middle frequency pulsed and high power pulsed magnetron sputtering for injection, molding components. Thin Solid Film. 2013, 528, 180-186. [CrossRef]

42. Wuhrer, R.; Yeung, W.Y. A comparative study of magnetron co-sputtered nanocrystalline titanium aluminium and chromium aluminium nitride coatings. Scr. Mater. 2004, 50, 1461-1466. [CrossRef]

43. Tritremmel, C. Comparison of Magnetron Sputtering and Arc Evaporation by Al-Cr-N Hard Coating. Diploma Thesis, Montanuniversität Leoben, Leoben, Austria, 2007.

44. Bobzin, K.; Lugscheider, E.; Nickel, R.; Bagcivan, N.; Kramer, A. Wear behavior of $\mathrm{Cr}_{1-x} \mathrm{Al}_{x} \mathrm{~N}$ PVD-coatings in dry running conditions. Wear 2007, 263, 1274-1280. [CrossRef]

45. Wang, Y.X.; Zhang, S.; Lee, J.W.; Lew, W.S.; Li, B. Influence of bias voltage on the hardness and toughness of CrAlN coatings via magnetron sputtering. Surf. Coat. Technol. 2012, 206, 5103-5107. [CrossRef] 
46. Drnovšek, A.; Rebelo de Figueiredo, M.; Vo, H.; Xia, A.; Vachhani, S.J.; Kolozsvár, S.; Hosemann, P.; Franz, R. Correlating high temperature mechanical and tribological properties of CrAlN and CrAlSiN hard coatings. Surf. Coat. Technol. 2019, 372, 361-368. [CrossRef]

47. Kim, G.S.; Lee, S.Y. Microstructure and mechanical properties of AlCrN films deposited by CFUBMS. Surf. Coat. Technol. 2006, 201, 4361-4366. [CrossRef]

48. Weirather, T.; Czettl, C.; Polcik, P.; Kathrein, M.; Mitterer, C. Industrial-scale sputter deposition of $\mathrm{Cr}_{1-x} \mathrm{Al}_{x}$ coatings with $0.21 \leq$ $x \leq 0.74$ from segmented targets. Surf. Coat. Technol. 2013, 232, 303-310. [CrossRef]

49. Sugishima, A.; Kajioka, H.; Makino, Y. Phase transition of pseudobinary Cr-Al-N films deposited by magnetron sputtering method. Surf. Coat. Technol. 1997, 97, 590-594. [CrossRef]

50. Makino, Y.; Nogi, K. Synthesis of pseudobinary Cr-Al-N films with B1 structure by rf-assisted magnetron sputtering method. Surf. Coat. Technol. 1998, 98, 1008-1012. [CrossRef]

51. Banakh, O.; Schmid, P.E.; Sanjinés, R.; Lévy, F. High-temperature oxidation resistance of $\mathrm{Cr}_{1-x} \mathrm{Al}_{x} \mathrm{~N}$ thin films deposited by reactive magnetron sputtering. Surf. Coat. Technol. 2003, 163, 57-61. [CrossRef]

52. Shah, H.N.; Jayaganthan, R. Influence of Al contents on the microstructure, mechanical, and wear properties of magnetron sputtered CrAlN coatings. J. Mater. Eng. Perform. 2012, 21, 2002-2009. [CrossRef]

53. Anders, A. Tutorial: Reactive high power impulse magnetron sputtering (R-HiPIMS). J. Appl. Phys. 2017, 121, 171101. [CrossRef]

54. Hsiao, Y.-C.; Lee, J.-W.; Yang, Y.-C.; Lou, B.-S. Effects of duty cycle and pulse frequency on the fabrication of AlCrN thin films deposited by high power impulse magnetron sputtering. Thin Solid Film. 2013, 549, 281-291. [CrossRef]

55. Avila, P.R.T.; da Silva, E.P.; Rodrigues, A.M.; Aristizabal, K.; Pineda, F.; Coelho, R.S.; Garcia, G.L.; Soldera, F.; Walczak, M.; Pinto, H.C. On manufacturing multilayer-like nanostructures using misorientation gradients in PVD films. Sci. Rep. 2019, 9, 15898. [CrossRef]

56. Tang, J.F.; Lin, C.Y.; Yang, F.C.; Chang, C.L. Influence of nitrogen content and bias voltage on residual stress and the tribological and mechanical properties of CrAlN films. Coatings 2020, 10, 546. [CrossRef]

57. Zheng, J.; Zhou, H.; Gui, B.; Luo, Q.; Li, H.; Wang, Q. Influence of power pulse parameters on the microstructure and properties of the AlCrN coatings by a modulated pulsed power magnetron sputtering. Coatings 2017, 7, 216. [CrossRef]

58. Chen, W.; Hu, T.; Hong, Y.; Zhang, D.; Meng, X. Comparison of microstructures, mechanical and tribological properties of arc-deposited AlCrN, AlCrBN and CrBN coatings on Ti-6Al-4V alloy. Surf. Coat. Technol. 2020, 404, 126429. [CrossRef]

59. Lin, J.; Mishra, B.; Moore, J.J.; Sproul, W.D. Microstructure, mechanical and tribological properties of $\mathrm{Cr}_{1-x} \mathrm{Al}_{x} \mathrm{~N}$ films deposited by pulsed-closed field unbalanced magnetron sputtering (P-CFUBMS). Surf. Coat. Technol. 2006, 201, 4329-4334. [CrossRef]

60. Hasegawa, H.; Masahiro Kawate, M.; Suzuki, T. Effects of $\mathrm{Al}$ contents on microstructures of $\mathrm{Cr}_{1-x} \mathrm{Al}_{x} \mathrm{~N}$ and $\left(\mathrm{Zr}_{1-x} \mathrm{Al}_{x}\right) \mathrm{N}$ films synthesized by cathodic arc method. Surf. Coat. Technol. 2005, 200, 2409-2413. [CrossRef]

61. Reiter, A.E.; Derflinger, V.H.; Hanselmann, B.; Bachmann, T.; Sartory, B. Investigation of the properties of $\mathrm{Al}_{1-x} \mathrm{Cr}_{x}$ coatings prepared by cathodic arc evaporation. Surf. Coat. Technol. 2005, 200, 2114-2122. [CrossRef]

62. Willmann, H.; Mayrhofer, P.H.; Persson, P.O.A.; Reiter, A.E.; Hultman, L.; Mitterer, C. Thermal stability of Al-Cr-N hard coatings. Scr. Mater. 2006, 54, 1847-1851. [CrossRef]

63. Mayrhofer, P.H.; Willmann, H.; Reiter, A.E. Structure and phase evolution of Cr-Al-N coatings during annealing. Surf. Coat. Technol. 2008, 202, 4935-4938. [CrossRef]

64. Mayrhofer, P.H.; Music, D.; Reeswinkel, T.; Fuß, H.-G.; Schneider, J.M. Structure, elastic properties and phase stability of $\mathrm{Cr}_{1-\mathrm{x}} \mathrm{Al}_{\mathrm{x}} \mathrm{N}$. Acta Mater. 2008, 56, 2469-2475. [CrossRef]

65. Bartosik, M.; Holec, D.; Apel, D.; Klaus, M.; Genzel, C.; Keckes, J.; Arndt, M.; Polcik, P.; Koller, C.M.; Mayrhofer, P.H. Thermal expansion of Ti-Al-N and Cr-Al-N coatings. Scripta Mater. 2017, 127, 182-185. [CrossRef]

66. Sabitzer, C.; Paulitsch, J.; Kolozsvári, S.; Rachbauer, R.; Mayrhofer, P.H. Influence of bias potential and layer arrangement on structure and mechanical properties of arc evaporated Al-Cr-N coatings. Vacuum 2014, 106, 49-52. [CrossRef]

67. Kalss, W.; Reiter, A.; Derflinger, V.; Gey, C.; Endrino, J.L. Modern coatings in high performance cutting applications. Int. J. Refract. Met. Hard Mater. 2006, 24, 399-404. [CrossRef]

68. Martan, J.; Benes, P. Thermal properties of cutting tool coatings at high temperatures. Thermochim. Acta 2012, 539, 51-55. [CrossRef]

69. Böttger, P.H.M.; Gusarov, A.V.; Shklover, V.; Patscheider, J.; Sobiech, M. Anisotropic layered media with microinclusions: Thermal properties of arc-evaporation multilayer metal nitrides. Int. J. Therm. Sci. 2014, 77, 75-83. [CrossRef]

70. Zhou, L.; Holec, D.; Mayrhofer, P.H. First-principles study of elastic properties of cubic $\mathrm{Cr}_{1-x} \mathrm{Al}_{x} \mathrm{~N}$ alloys. J. Appl. Phys. 2013, 113, 043511. [CrossRef]

71. Buchinger, J.; Wagner, A.; Chen, Z.; Zhang, Z.L.; Holec, D.; Mayrhofer, P.H.; Bartosik, M. Fracture toughness trends of modulusmatched TiN/(Cr,Al)N thin film superlattices. Acta Mater. 2021, 202, 376-386. [CrossRef]

72. Soldán, J.; Neidhardt, J.; Sartory, B.; Kaindl, R.; Čerstvý, R.; Mayrhofer, P.H.; Tessadri, R.; Polcik, P.; Lechthaler, M.; Mitterer, C. Structure-property relations of arc-evaporated Al-Cr-Si-N coatings. Surf. Coat. Technol. 2008, 202, 3555-3562. [CrossRef]

73. Warcholinski, B.; Gilewicz, A.; Myslinski, P.; Dobruchowska, E.; Murzynski, D.; Kuznetsova, T.A. Effect of silicon concentration on the properties of Al-Cr-Si-N coatings deposited using cathodic arc evaporation. Materials 2020, 13, 4717. [CrossRef] [PubMed]

74. Willman, H.; Mayrhofer, P.H.; Hultman, L.; Mitterer, C. Hardness evolution of Al-Cr-N coatings under thermal load. Mater. Res. 2008, 23, 2880-2885. [CrossRef] 
75. Meindlhumer, M.; Klima, S.; Jäger, N.; Stark, A.; Hruby, H.; Mitterer, C.; Kecks, J.; Daniel, R. Stress-controlled decomposition routes in cubic AlCrN films assessed by in-situ high-temperature high-energy grazing incidence transmission $\mathrm{X}$-ray diffraction. Sci. Rep. 2019, 9, 1-14. [CrossRef] [PubMed]

76. Lin, J.; Mishra, B.; Moore, J.J.; Sproul, W.D. Study of the oxidation behavior of CrN and CrAlN thin films inir using DSC and TGA analyses. Surf. Coat. Technol. 2008, 202, 3272-3283. [CrossRef]

77. Chim, Y.C.; Ding, Z.Z.; Zeng, X.T.; Zhang, S. Oxidation resistance of TiN, CrN, TiAlN and CrAlN coatings deposited by lateralrotating cathode arc. Thin Solid Film. 2009, 517, 4845-4849. [CrossRef]

78. Feng, Y.-P.; Zhang, L.; Ke, R.-X.; Wan, Q.-L.; Wang, Z.; Lu, Z.-H. Thermal stability and oxidation behavior of AlTiN, AlCrN and AlCrSiWN coatings. Int. J. Refract. Met. Hard Mater. 2014, 43, 241-249. [CrossRef]

79. Khamseh, S.; Nose, M.; Kawabata, T.; Matsuda, K.; Ikeno, S. Oxidation resistance of CrAlN films with different microstructures prepared by pulsed DC balanced magnetron sputtering system. Mater. Trans. 2010, 51, 271-276. [CrossRef]

80. Polcar, T.; Cavaleiro, A. High temperature properties of CrAlN, CrAlSiN and AlCrSiN coatings-Structure and oxidation. Mater. Chem. Phys. 2011, 129, 195-201. [CrossRef]

81. Endrino, J.; Fox-Rabinovich, G.; Reiter, A.; Veldhuis, S.; Galindo, R.E.; Albella, J.; Marco, J. Oxidation tuning in AlCrN coatings. Surf. Coat. Technol. 2007, 201, 4505-4511. [CrossRef]

82. Souza, P.S.; Santos, A.J.; Cotrim, M.A.P.; Abrão, A.M.; Câmara, M.A. Analysis of the surface energy interactions in the tribological behavior of AlCrN and TiAlN coatings. Tribol. Int. 2020, 146, 106206. [CrossRef]

83. Reiter, A.E.; Mitterer, C.; de Figueiredo, M.R.; Franz, R. Abrasive and adhesive wear behavior of arc-evaporated $\mathrm{Al}_{1-x} \mathrm{Cr}_{x} \mathrm{~N} \mathrm{hard}$ coatings. Tribol. Lett. 2010, 37, 605-611. [CrossRef]

84. Mo, J.L.; Zhu, M.H. Tribological oxidation behaviour of PVD hard coatings. Tribol. Int. 2009, 42, 1758-1764. [CrossRef]

85. Anders. A structure zone diagram including plasma-based deposition and ion etching. Thin Solid Film. 2010, 518, 4087-4090. [CrossRef]

86. Abadias, G.; Chason, E.; Keckes, J.; Sebastiani, M.; Thompson, G.B.; Barthel, E.; Doll, G.L.; Murray, C.E.; Stoessel, C.H.; Martinu, L. Review Article: Stress in thin films and coatings: Current status, challenges and prospects. J. Vac. Sci. Technol. A 2018, 36, 020801. [CrossRef]

87. Lomello, F.; Sanchette, F.; Schuster, F.; Tabarant, M.; Billard, A. Influence of bias voltage on properties of AlCrN coatings prepared by cathodic arc deposition. Surf. Coat. Technol. 2013, 224, 77-81. [CrossRef]

88. Kohlscheen, J.; Shibata, T. Phase and residual stress evaluation of dual-phase $\mathrm{Al}_{70} \mathrm{Cr}_{30} \mathrm{~N}$ and $\mathrm{Al}_{80} \mathrm{Cr}_{20} \mathrm{~N}$ PVD films. Crystals 2019, 9, 362. [CrossRef]

89. Tritremmel, C.; Daniel, R.; Lechthaler, M.; Rudigier, H.; Polcik, P.; Mitterer, C. Microstructure and mechanical properties of nanocrystalline Al-Cr-B-N thin films. Surf. Coat. Technol. 2012, 213, 1-7. [CrossRef]

90. Gilewicz, A.; Jedrzejewski, R.; Myslinski, P.; Warcholinski, B. Structure, morphology and mechanical properties of AlCrN coatings deposited by cathodic arc evaporation. J. Mater. Eng. Perform. 2019, 28, 1522-1531. [CrossRef]

91. Warcholinski, B.; Gilewicz, A.; Myslinski, P.; Dobruchowska, E.; Murzynski, D. Structure and Properties of AlCrN Coatings Deposited Using Cathodic Arc Evaporation. Coatings 2020, 10, 793. [CrossRef]

92. Wang, L.; Zhang, S.; Chen, Z.; Li, J.; Li, M. Influence of deposition parameters on hard Cr-Al-N coatings deposited by multi-arc ion plating. Appl. Surf. Sci. 2012, 258, 3629-3636. [CrossRef]

93. Vetter, J.; Ishikawa, T. Developments of Plasma Enhanced Evaporator for High Al Coating $\left(A l_{70} C r_{30}\right) N O$; Unpublished Report; Metaplas Ionon GmbH: Bergisch Gladbach, Germany, 2003.

94. Gilewicz, A.; Jedrzejewski, R.; Myslinski, P.; Warcholinski, B. Influence of Substrate Bias Voltage on Structure, Morphology and Mechanical Properties of AlCrN Coatings Synthesized Using Cathodic Arc Evaporation. Tribol. Ind. 2019, 41, 484-497. [CrossRef]

95. Bobzin, K.; Brögelmann, T.; Brugnara, R.H. Aluminum-rich HPPMS $\left(\mathrm{Cr}_{1-x} \mathrm{Al}_{x}\right) \mathrm{N}$ coatings deposited with different target compositions and at various pulse lengths. Vacuum 2015, 122, 201-207. [CrossRef]

96. Jeager, N.; Klima, S.; Hruby, H.; Julin, J.; Burghammer, M.; Keckes, J.F.; Mitterer, C.; Daniel, R. Evolution of structure and residual stress of a fcc/hex-AlCrN multi-layered system upon thermal loading revealed by cross-sectional Xray nano-diffraction. Acta Mater. 2019, 162, 55-66. [CrossRef]

97. Forsén, R.; Johansson, M.P.; Odén, M.; Ghafoor, N. Effects of Ti alloying of AlCrN coatings on thermal stability and oxidation resistance. Thin Solid Film. 2013, 534, 394-402. [CrossRef]

98. Hasegawa, H.; Yamamoto, T.; Suzuki, T.; Yamamoto, K. The effects of deposition temperature and post-annealing on the crystal structure and mechanical property of TiCrAlN films with high Al contents. Surf. Coat. Technol. 2006, 200, 2864-2869. [CrossRef]

99. Yamamoto, K.; Sato, T.; Takahara, K.; Hanaguri, K. Properties of (Ti,Cr,Al)N coatings with high Al content deposited by new plasma enhanced arc-cathode. Surf. Coat. Technol. 2003, 174, 620-626. [CrossRef]

100. Xu, Y.X.; Hu, C.; Chen, L.; Pei, F.; Du, Y. Effect of V-addition on the thermal stability and oxidation resistance of CrAlN coatings Ceram. Int. 2018, 44, 7013-7019. [CrossRef]

101. Franz, R.; Neidhardt, J.; Sartory, B.; Tessadri, R.; Mitterer, C. Micro- and bonding structure of arc-evaporated AlCrVN hard coatings. Thin Solid Film. 2008, 516, 6151-6157. [CrossRef]

102. Bobzin, K.; Bagcivan, N.; Ewering, M.; Brugnara, R.H.; Theiß, S. DC-MSIP/HPPMS (Cr,Al,V)N and (Cr,Al,W)N thin films for high-temperature friction reduction. Surf. Coat. Technol. 2011, 205, 2887-2892. [CrossRef] 
103. Iram, S.; Cai, F.; Wang, J.; Zhang, J.; Liang, J.; Ahmad, F.; Zhang, S. Effect of addition of Mo or V on the structure and cutting performance of AlCrN-based coatings. Coatings 2020, 10, 298. [CrossRef]

104. Sánchez-López, J.C.; Contreras, A.; Domínguez-Meister, S.; García-Luis, A.; Brizuela, M. Tribological behaviour at high temperature of hard CrAlN coatings doped with Y or Zr. Thin Solid Film. 2014, 550, 413-420. [CrossRef]

105. Klimashin, F.F.; Mayrhofer, P.H. Ab initio-guided development of super-hard Mo-Al-Cr-N coatings. Scr. Mater. 2017, 140, 27-30. [CrossRef]

106. Bobzin, K.; Brögelmann, T.; Kalscheuer, C. Arc PVD (Cr,Al,Mo)N and (Cr,Al,Cu)N coatings for mobility applications. Surf. Coat. Technol. 2020, 384, 125046. [CrossRef]

107. Tillmann, W.; Dias, N.F.L.; Stangier, D. Effect of Hf on the microstructure, mechanical properties, and oxidation behavior of sputtered CrAlN films. Vacuum 2018, 154, 208-213. [CrossRef]

108. Hu, C.; Xu, Y.X.; Chen, L.; Pei, F.; Zhang, L.J.; Du, Y. Structural, mechanical and thermal properties of CrAlNbN coatings. Surf. Coat. Technol. 2018, 349, 894-900. [CrossRef]

109. Rovere, F.; Mayrhofer, P.H.; Reinholdt, A.; Mayer, J.; Schneider, J.M. The effect of yttrium incorporation on the oxidation resistance of Cr-Al-N coatings. Surf. Coat. Technol. 2008, 202, 5870-5875. [CrossRef]

110. Rovere, F.; Music, D.; Schneider, J.M.; Mayrhofer, P.H. Experimental and computational study on the effect of yttrium on the phase stability of sputtered Cr-Al-Y-N hard coatings. Acta Mater. 2010, 58, 2708-2715. [CrossRef]

111. Qi, Z.B.; Wu, Z.T.; Wang, Z.C. Improved hardness and oxidation resistance for CrAlN hard coatings with $\mathrm{Y}$ addition by magnetron co-sputtering. Surf. Coat. Technol. 2014, 259, 146-151. [CrossRef]

112. Rojas, T.C.; Domínguez-Meister, S.; Brizuela, M.; Sanchez-Lopez, J.C. Influence of Al and Y content on the oxidation resistance of CrAlYN protective coatings for high temperature applications: New insights about the Y role. J. Alloys Compd. 2019, 773, 1172-1181. [CrossRef]

113. Du, H.; Wang, L.; Young, M.; Zhao, H.; Xiong, J.; Wan, W. Structure and properties of lanthanum doped AlCrN coatings. Surf. Coat. Technol. 2018, 337, 439-446. [CrossRef]

114. Shtansky, D.V.; Kiryukhantsev-Korneev, P.V.; Sheveyko, A.N.; Mavrin, B.N.; Rojas, C.; Fernandez, A.; Levashov, E.A. Comparative investigation of $\operatorname{TiAlC}(\mathrm{N})$, $\operatorname{TiCrAlC}(\mathrm{N})$, and $\mathrm{CrAlC}(\mathrm{N})$ coatings deposited by sputtering of MAX-phase $\mathrm{Ti}_{2-\mathrm{x}} \mathrm{Cr}_{\mathrm{x}} \mathrm{AlC}$ targets. Surf. Coat. Technol. 2009, 203, 3595-3609. [CrossRef]

115. Tillmann, W.; Stangier, D.; Roese, P.; Shamout, K.; Berges, U.; Westphal, C.; Debus, J. Structural and mechanical properties of carbon incorporation in DC/HiPIMS CrAlN coatings. Surf. Coat. Technol. 2019, 374, 774-783. [CrossRef]

116. Stueber, M.; Albers, U.; Leiste, H.; Ulrich, S.; Holleck, H.; Barna, P.B.; Kovacs, A.; Hovsepian, P.; Gee, I. Multifunctional nanolaminated PVD coatings in the system Ti-Al-N-C by combination of metastable fcc phases and nanocomposite microstructures. Surf. Coat. Technol. 2006, 200, 6162-6171. [CrossRef]

117. Lee, D.B.; Nguyen, T.D.; Kim, S.K. Air-oxidation of nano-multilayered CrAlSiN thin films between 800 and $1000{ }^{\circ} \mathrm{C}$. Surf. Coat. Technol. 2009, 203, 1199-1204. [CrossRef]

118. Chen, H.W.; Chan, Y.C.; Lee, J.W.; Duh, J.G. Oxidation behavior of Si-doped nanocomposite CrAlSiN coatings. Surf. Coat. Technol. 2010, 205, 1189-1194. [CrossRef]

119. Tritremmel, C.; Daniel, R.; Mayerhofer, P.H.; Lechthaler, M.; Polcik, P.; Mitterer, C. Oxidation behavior of arc evaporated Al-Cr-Si-N thin films. J. Vac. Sci. Technol. A 2012, 30, 061501. [CrossRef]

120. Wu, W.; Chen, W.; Yang, S.; Lin, Y.; Zhang, S.; Cho, T.-Y.; Lee, G.H.; Kwon, S.-C. Design of AlCrSiN multilayers and nanocomposite coating for HSS cutting tools. Appl. Surf. Sci. 2015, 351, 803-810. [CrossRef]

121. Cai, F.; Gao, Y.; Zhang, S.; Zhang, L.; Wang, Q. Gradient architecture of Si containing layer and improved cutting performance of AlCrSiN coated tools. Wear 2019, 424, 193-202. [CrossRef]

122. Wang, Y.X.; Zhang, S.; Lee, J.W.; Lew, W.S.; Sun, D.; Li, B. Toward hard yet tough CrAlSiN coatings via compositional grading. Surf. Coat. Technol. 2013, 231, 346-352. [CrossRef]

123. Sun, S.Q.; Ye, Y.W.; Wang, Y.X.; Liu, M.Q.; Liu, X.; Li, J.L.; Wang, L.P. Structure and tribological performances of CrAlSiN coatings with different Si percentages in seawater. Tribol. Int. 2017, 115, 591-599. [CrossRef]

124. Haršáni, M.; Ghafoor, N.; Calamba, K.; Zacková, P.; Sahul, M.; Vopát, T.; Satrapinskyy, L.; Čaplovičová, M. Čaplovič Adhesivedeformation relationships and mechanical properties of nc-AlCrN/a-SiN $x$ hard coatings deposited at different bias voltages. Thin Solid Film. 2018, 650, 11-19. [CrossRef]

125. Gao, Y.; Cai, F.; Zhang, L.; Zhang, S. Structure optimization and cutting performance of gradient multilayer AlCrSiN films with ion source etching pretreatment. J. Mater. Eng. Perform. 2020, 29, 997-1006. [CrossRef]

126. Jäger, N.; Meindlhumer, M.; Spor, S.; Hruby, H.; Julin, J.; Stark, A.; Nahif, F.; Keckes, J.; Mitterer, C.; Daniel, R. Microstructural evolution and thermal stability of $\mathrm{AlCr}(\mathrm{Si}) \mathrm{N}$ hard coatings revealed by in-situ high-temperature high-energy grazing incidence transmission X-ray diffraction. Acta Mater. 2020, 186, 545-554. [CrossRef]

127. Kolaklieva, L.; Kakanakov, R.; Stefanov, P.; Kovacheva, D.; Atanasova, G.; Russev, S.; Chitanov, V.; Cholakova, T.; Bahchedjiev, C. Mechanical and structural properties of nanocomposite CrAlSiN-AlSiN coating with periodically modulated composition. Coatings 2020, 10, 41. [CrossRef]

128. Wang, Q.M.; Kim, K.H. Microstructural control of Cr-Si-N films by a hybrid arc ion plating and magnetron sputtering process. Acta Mater. 2009, 57, 4974-4987. [CrossRef] 
129. Pélisson, A.; Hug, H.J.; Patscheider, J. Morphology, microstructure evolution and optical properties of Al-Si-N nanocomposite coating. Surf. Coat. Technol. 2014, 257, 114-120. [CrossRef]

130. Schmitt, T.; Steyer, P.; Fontaine, J.; Mary, N.; Esnouf, C.; O'Sullivan, M.; Sanchette, F. Cathodic arc deposited (Cr,Si $x)$ N coatings: From solid solution to nanocomposite structure. Surf. Coat. Technol. 2012, 213, 117-125. [CrossRef]

131. Rafaja, D.; Dopita, M.; Růžička, M.; Klemm, V.; Heger, D.; Schreiber, G.; Šíma, M. Microstructure development in Cr-Al-Si-N nanocomposites deposited by cathodic arc evaporation. Surf. Coat. Technol. 2006, 201, 2835-2843. [CrossRef]

132. Geng, D.; Li, H.; Zhang, Q.; Zhang, X.; Wang, C.; Wu, Z.; Wang, Q. Effect of incorporating oxygen on microstructure and mechanical properties of AlCrSiON coatings deposited by arc ion plating. Surf. Coat. Technol. 2017, 310, 223-230. [CrossRef]

133. Chen, Y.; Du, H.; Chen, M.; Yang, J.; Xiong, J.; Zhao, H. Structure and wear behavior of AlCrSiN-based coatings. Appl. Surf. Sci. 2016, 370, 176-183. [CrossRef]

134. Kiryukhantsev-Korneev, P.V.; Pierson, J.F.; Kuptsov, K.A.; Shtansky, D.V. Hard Cr-Al-Si-B-(N) coatings deposited by reactive and non-reactive magnetron sputtering of CrAlSiB target. Appl. Surf. Sci. 2014, 314, 104-111. [CrossRef]

135. Zhang, L.; Chen, Y.; Feng, Y.-P.; Chen, S.; Wan, Q.-L.; Zhu, J.-F. Electrochemical characterization of AlTiN, AlCrN and AlCrSiWN coatings. Int. J. Refract. Met. Hard Met. 2015, 53, 68-73. [CrossRef]

136. Tillmann, W.; Fehr, A.; Stangier, D. Powder metallurgic fabricated plug targets for the synthesis of AlCrSiWN multicomponent coating systems. Int. J. Refract. Met. Hard Mater. 2019, 85, 105081. [CrossRef]

137. Wang, Y.X.; Zhang, S.; Leeb, J.-W.; Lew, W.S.; Li, B. Toughening effect of Ni on nc-CrAlN/a-SiN ${ }_{x}$ hard nanocomposite. Appl. Surf. Sci. 2013, 265, 418-423. [CrossRef]

138. Najafi, H.; Karimi, A.; Alexander, D.; Dessarzin, P.; Morstein, M. Effects of Si and Y in structural development of $(\mathrm{Al}, \mathrm{Cr}, \mathrm{Si} / \mathrm{Y}) \mathrm{O}_{x} \mathrm{~N}_{1-x}$ thin films $\mathrm{N}$ deposited by magnetron sputtering. Thin Solid Film. 2013, 549, 224-231. [CrossRef]

139. Chen, M.; Chen, W.; Cai, F.; Zhang, S.; Wang, Q. Structural evolution and electrochemical behaviors of multilayer Al-Cr-Si-N coatings. Surf. Coat. Technol. 2016, 296, 33-39. [CrossRef]

140. Bakalova, T.; Petkov, N.; Bahchedzhiev, H.; Kejzlar, P.; Louda, P.; Ďurák, M. improving the tribological and mechanical properties of an aluminium alloy by deposition of AlSiN and AlCrSiN coatings. Manuf. Technol. 2017, 17, 824-830. [CrossRef]

141. Tang, J.-F.; Huang, C.-H.; Lin, C.-Y.; Yang, F.-C.; Chang, C.-L. Effects of substrate rotation speed on structure and adhesion properties of $\mathrm{CrN} / \mathrm{CrAlSiN}$ multilayer coatings prepared using high-power impulse magnetron sputtering. Coatings 2020, 10, 742. [CrossRef]

142. Tao, H.; Tsai, M.T.; Chen, H.-W.; Huang, J.C.; Duh, J.-G. Improving high-temperature tribological characteristics on nanocomposite CrAlSiN coating by Mo doping. Surf. Coat. Technol. 2018, 349, 752-756. [CrossRef]

143. Liu, Z.R.; Peng, B.; Xu, Y.X.; Zhang, Q.; Wang, Q.; Chen, L. Influence of Ni-addition on mechanical, tribological properties and oxidation resistance of AlCrSiN coatings. Ceram. Int. 2019, 45, 3735-3742. [CrossRef]

144. Liu, Z.R.; Xu, Y.X.; Peng, B.; Wei, W.; Chen, L.; Wang, Q. Structure and property optimization of Ni-containing AlCrSiN coatings by nano-multilayer construction. J. Alloys Compd. 2019, 808, 151630. [CrossRef]

145. Yamamoto, K.; Kujime, S.; Takahara, K. Structural and mechanical property of Si incorporated (Ti,Cr,Al)N coatings deposited by arc ion plating process. Surf. Coat. Technol. 2005, 200, 1383-1390. [CrossRef]

146. Chen, W.; Hu, T.; Wang, C.; Xiao, H.; Meng, X. The effect of microstructure on corrosion behavior of a novel AlCrTiSiN ceramic coating. Ceram. Int. 2020, 46, 12584-12592. [CrossRef]

147. Dai, W.; Kwon, S.-H.; Wang, Q.; Liu, J. Influence of frequency and $\mathrm{C}_{2} \mathrm{H}_{2}$ flow on growth properties of diamond-like carbon coatings with $\mathrm{AlCrSi}$ co-doping deposited using a reactive high power impulse magnetron sputtering. Thin Solid Film. 2018, 647, 26-32. [CrossRef]

148. Vetter. J. Layer System for the Formation of a Surface Layer on a Surface of a Substrate and Also Arc Vaporization Source for the Manufacture of a Layer System. U.S. Patent 8,119,261 B2, 21 February 2012.

149. Yamamoto, K.; Kujime, S.; Fox-Rabinovich, G. Effect of alloying element (Si,Y) on properties of AIP deposited (Ti,Cr,Al)N coating. Surf. Coat. Technol. 2008, 203, 579-583. [CrossRef]

150. Shen, W.-J.; Tsai, M.-H.; Yeh, J.-W. Machining Performance of Sputter-Deposited $\left(\mathrm{Al}_{0.34} \mathrm{Cr}_{0.22} \mathrm{Nb}_{0.11} \mathrm{Si}_{0.11} \mathrm{Ti}_{0.22}\right)_{50} \mathrm{~N}_{50} \mathrm{High} \mathrm{Entropy}$ Nitride Coatings. Coatings 2015, 5, 312-325. [CrossRef]

151. Chen, W.; Yan, A.; Meng, X.; Wu, D.; Yao, D.; Zhang, D. Microstructural change and phase transformation in each individual layer of a nano-multilayered AlCrTiSiN high-entropy alloy nitride coating upon annealing. Appl. Surf. Sci. 2018, 462, 1017-1028. [CrossRef]

152. Qiu, Y.; Zhang, S.; Lee, J.-W.; Li, B.; Wang, Y.; Zhao, D. Self-lubricating CrAlN/VN multilayer coatings at room temperature. Appl. Surf. Sci. 2013, 279, 189-196. [CrossRef]

153. Wang, Y.; Lee, J.-W.; Duh, J.-G. Mechanical strengthening in self-lubricating CrAlN/VN multilayer coatings for improved high-temperature tribological characteristics. Surf. Coat. Technol. 2016, 303, 12-17. [CrossRef]

154. Hosokawa, A.; Saito, R.; Ueda, T. Milling characteristics of VN/AlCrN-multilayer PVD coated tools with lubricity and heat resistance. CIRP Ann. Manuf. Technol. 2020, 69, 49-52. [CrossRef]

155. Liew, W.Y.H.; Jie, J.L.L.; Yan, L.Y.; Dayou, J.; Sipaut, C.S.; Madlan, M.F.B. Frictional and wear behaviour of AlCrN, TiN, TiAlN single-layer coatings, and TiAlN/AlCrN, AlN/TiN nano-multilayer coatings in dry sliding. Procedia Eng. 2013, 68, 512-517. [CrossRef] 
156. Kumar, T.S.; Prabu, S.B.; Manivasagam, G. Metallurgical characteristics of TiAlN/AlCrN coating synthesized by the PVD Process on a cutting insert. J. Mater. Eng. Perform. 2014, 23, 2877-2884. [CrossRef]

157. Chang, Y.-Y.; Weng, S.-Y.; Chen, C.-H.; Fu, F.-X. High temperature oxidation and cutting performance of AlCrN, TiVN and multilayered AlCrN/TiVN hard coatings. Surf. Coat. Technol. 2017, 332, 494-503. [CrossRef]

158. Xiao, B.J.; Li, H.X.; Mei, H.J. A study of oxidation behavior of AlTiN-and AlCrN-based multilayer coatings. Surf. Coat. Technol. 2018, 333, 229-237. [CrossRef]

159. Chen, W.; Lin, Y.; Zheng, J.; Zhang, S.; Liu, S.; Kwon, S. Preparation and characterization of CrAlN/TiAlSiN nano-multilayers by cathodic vacuum arc. Surf. Coat. Technol. 2015, 265, 205-211. [CrossRef]

160. He, L.; Chen, L.; Xu, Y. Interfacial structure, mechanical properties and thermal stability of CrAlSiN/CrAlN multilayer coatings. Mater. Charact. 2017, 125, 1-6. [CrossRef]

161. Seidl, W.M.; Bartosik, M.; Kolozsváric, S.; Bolvardid, H.; Mayrhofer, P.H. Mechanical properties and oxidation resistance of Al-Cr-N/Ti-Al-Ta-N multilayer coatings. Surf. Coat. Technol. 2018, 347, 427-433. [CrossRef]

162. Ahmad, F.; Zhang, L.; Zheng, J.; Sidra, I.; Zhang, S. Characterization of AlCrN and AlCrON coatings deposited on plasma nitrided AISI H13 steels using ion-source-enhanced arc ion plating. Coatings 2020, 10, 306. [CrossRef]

163. Raab, R.; Koller, C.M.; Kolozsvári, S.; Ramm, J.; Mayrhofer, P.H. Interfaces in arc evaporated Al-Cr-N/Al-Cr-O multi layers and their impact on hardness. Surf. Coat. Technol. 2017, 324, 236-242. [CrossRef]

164. Wang, X.; Luo, T.; Li, Q.; Cheng, X.; Li, K. High performance aperiodic metal-dielectric multilayer stacks for solar energy thermal conversion. Sol. Energy Mater. Sol. Cells 2019, 191, 372-380. [CrossRef]

165. Vetter, J. Oxynitrides and Oxides Deposited by Cathodic Vacuum Arc. In Metallic Oxynitride Thin Films by Reactive Sputtering and Related Deposition Methods: Process, Properties and Applications; Vaz, F., Martin, N., Fenker, M., Eds.; Bentham Science Publisher: Bussum, The Netherlands, 2013; pp. 265-284.

166. Khatibi, A.; Sjölen, J.; Greczynski, G.; Jensen, J.; Eklund, P.; Hultman, L. Structural and mechanical properties of Cr-Al-O-N thin films grown by cathodic arc deposition. Acta Mater. 2012, 60, 6494-6507. [CrossRef]

167. Khatibi, A.; Genvad, A.; Goethelid, E.; Jensen, J.; Eklund, P.; Hultman, L. Structural and mechanical properties of corundum and cubic $\left(\mathrm{Al}_{x} \mathrm{Cr}_{1-x}\right)_{2+y} \mathrm{O}_{3-y}$ coatings grown by reactive cathodic arc evaporation in as-deposited and annealed states. Acta Mater. 2013, 61, 4811-4822. [CrossRef]

168. Pilkington, A.; Dowey, S.J.; Toton, J.T.; Doyle, E.D. Machining with AlCr-oxinitride PVD coated cutting tools. Tribol. Int. 2013, 65, 303-313. [CrossRef]

169. Bobzin, K.; Brögelmann, T.; Kalscheuer, C.; Naderi, M. Hybrid dcMS/HPPMS PVD nitride and oxynitride hard coatings for adhesion and abrasion reduction in plastics processing. Surf. Coat. Technol. 2016, 308, 349-359. [CrossRef]

170. Bobzin, K.; Brögelmann, T.; Kalscheuer, C.; Liang, T. High-rate deposition of thick (Cr,Al)ON coatings by high speed physical vapor deposition. Surf. Coat. Technol. 2017, 322, 152-162. [CrossRef]

171. Wang, X.; Zhang, X.; Li, Q.; Min, J.; Cheng, X. Spectral properties of AlCrNO-based multi-layer solar selective absorbing coating during the initial stage of thermal aging upon exposure to air. Sol. Energy Mater. Sol. Cells 2018, 188, 81-92. [CrossRef]

172. Najafi, H.; Karimi, A.; Dessarzin, P.; Morstein, M. Correlation between anionic substitution and structural properties in $\mathrm{AlCr}\left(\mathrm{O}_{\mathrm{x}} \mathrm{N}_{1-\mathrm{x}}\right)$ coatings deposited by lateral rotating cathode arc PVD. Thin Solid Film. 2011, 520, 1597-1602. [CrossRef]

173. Stueber, M.; Diechle, D.; Leiste, H.; Ulrich, S. Synthesis of Al-Cr-O-N thin films in corundum and f.c.c. structure by reactive r.f magnetron sputtering. Thin Solid Film. 2011, 519, 4025-4031. [CrossRef]

174. Koller, C.M.; Stueber, M.; Mayrhofer, P.-H. Progress in the synthesis of Al- and Cr-based sesquioxide coatings for protective applications. J. Vac. Sci. Technol. A 2019, 37, 060802. [CrossRef]

175. Brögelmann, T.; Bobzin, K.; Kruppe, N.C.; Carlet, M. (Cr,Al)ON Deposited by Hybrid dcMS/HPPMS. A study on incorporation of Oxygen. Surf. Coat. Technol. 2019, 369, 238-243. [CrossRef]

176. Zhou, H.; Zheng, J.; Gui, B.; Geng, D.; Wang, Q. AlTiCrN coatings deposited by hybrid HIPIMS/D C magnetronco-sputtering. Vacuum 2017, 136, 129-136. [CrossRef]

177. Veprek, S.; Veprek-Heijman, M.J.G. Industrial applications of superhard nanocomposite coatings. Surf. Coat.Technol. 2008, 202, 5063-5073. [CrossRef]

178. Cheng, Y.T.; Qiu, W.Q.; Zhou, K.S.; Jiao, D.L.; Liu, Z.W.; Zhong, X.C.; Zhang, H. The influence of Cr content on the phase structure of the Al-rich Al-Cr-O films deposited by magnetron sputtering at low temperature. Ceram. Int. 2019, 45, 8175-8180. [CrossRef]

179. Najafi, H.; Karimi, A.; Dessarzin, P.; Morstein, M. Formation of cubic structured $\left(\mathrm{Al}_{1-x} \mathrm{Cr}_{x}\right)_{2+\delta} \mathrm{O}_{3}$ and its dynamic transition to corundum phase during cathodic arc evaporation. Surf. Coat. Technol. 2013, 214, 46-52. [CrossRef]

180. Almandoz, E.; Fuentes, G.G.; Fernández, J.; de Bujanda, J.M.; Rodríguez, R.J.; Pérez-Trujillo, F.J.; Alcalá, G.; Lousa, A.; Qin, Y. Chemical and mechanical stability of air annealed cathodic arc evaporated CrAlON coatings. Surf. Coat. Technol. 2018, 351, 153-161. [CrossRef]

181. Gao, Y.; Cai, F.; Fang, W.; Chen, Y.; Zhang, S.; Wang, Q. Effect of oxygen content on wear and cutting performance of AlCrON coatings. J. Mater. Eng. Perform. 2019, 28, 828-837. [CrossRef]

182. Stüber, M.; Albers, U.; Leiste, H.; Seemann, K.; Ziebert, C.; Ulrich, S. Magnetron sputtering of hard Cr-Al-N-O thin films. Surf. Coat. Technol. 2008, 203, 661-665. [CrossRef]

183. Diechle, D.; Stueber, M.; Leiste, H.; Ulrich, S. Combinatorial approach to the growth of $\alpha-\left(\mathrm{Al}_{1-x}, \mathrm{Cr}_{x}\right)_{2+\delta}\left(\mathrm{O}_{1-y}, \mathrm{~N}_{y}\right)_{3}$ solid solution strengthened thin films by reactive r.f. magnetron sputtering. Surf. Coat. Technol. 2011, 206, 1545-1551. [CrossRef] 
184. Gerth, J.; Larsson, M.; Wiklund, U.; Riddar, F.; Hogmark, S. On the wear of PVD-coated HSS hobs in dry gear cutting. Wear 2009, 266, 444-452. [CrossRef]

185. Cselle, T.; Morstein, M.; Luemkemann, A. QuadCoatings ${ }^{\circledR}$ new generation of PVD coatings for cutting tools. Werkzeug Tech. 2012, 130, 2-3.

186. Wang, B. An Investigation of the Adhesion Behavior of Aluminium on Various PVD Coatings Applied to H13 Tool Steel to Minimize Lubrication during High Pressure Die Casting. Ph.D. Thesis, Colorado School of Mines, Golden, CO, USA, 2016.

187. Uestuenyagiz, E.; Nielsen, C.V.; Tiedje, N.S.; Bay, N. Combined numerical and experimental determination of the convective heat transfer coefficient between an AlCrN-coated Vanadis 4E tool and Rhenus oil. Measurement 2018, 127, 565-570. [CrossRef]

188. Kim, D.; Swan, S.R.; He, B.; Khominich, V.; Bell, E.; Lee, S.-W.; Kim, T.-G. A study on the machinability of advanced arc PVD $\mathrm{AlCrN}$-coated tungsten carbide tools in drilling of CFRP/titanium alloy stacks. Carbon Lett. 2020. [CrossRef] 